THE LAND AND IIS PROELEMS

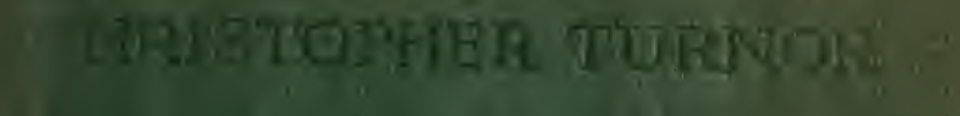

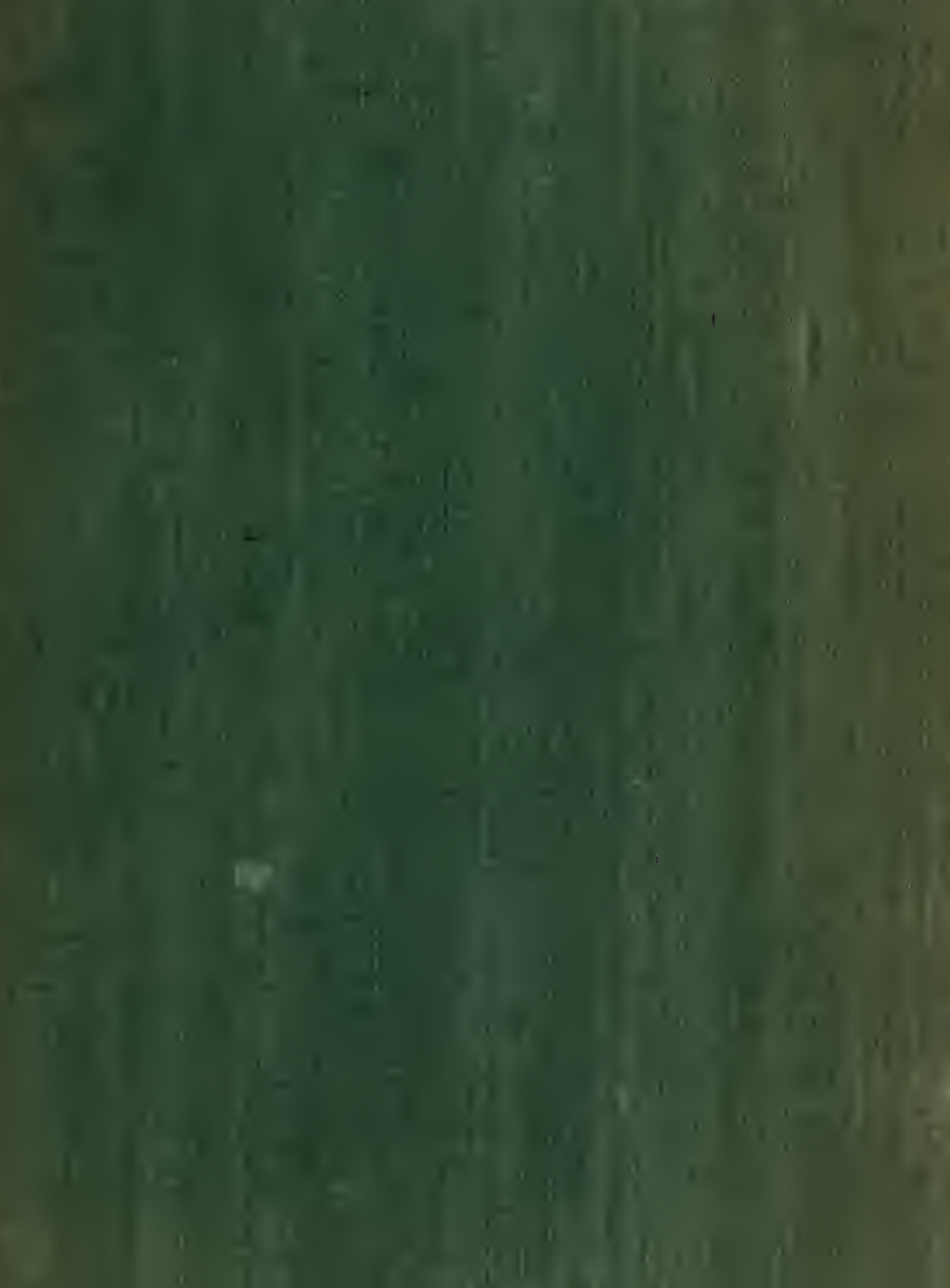



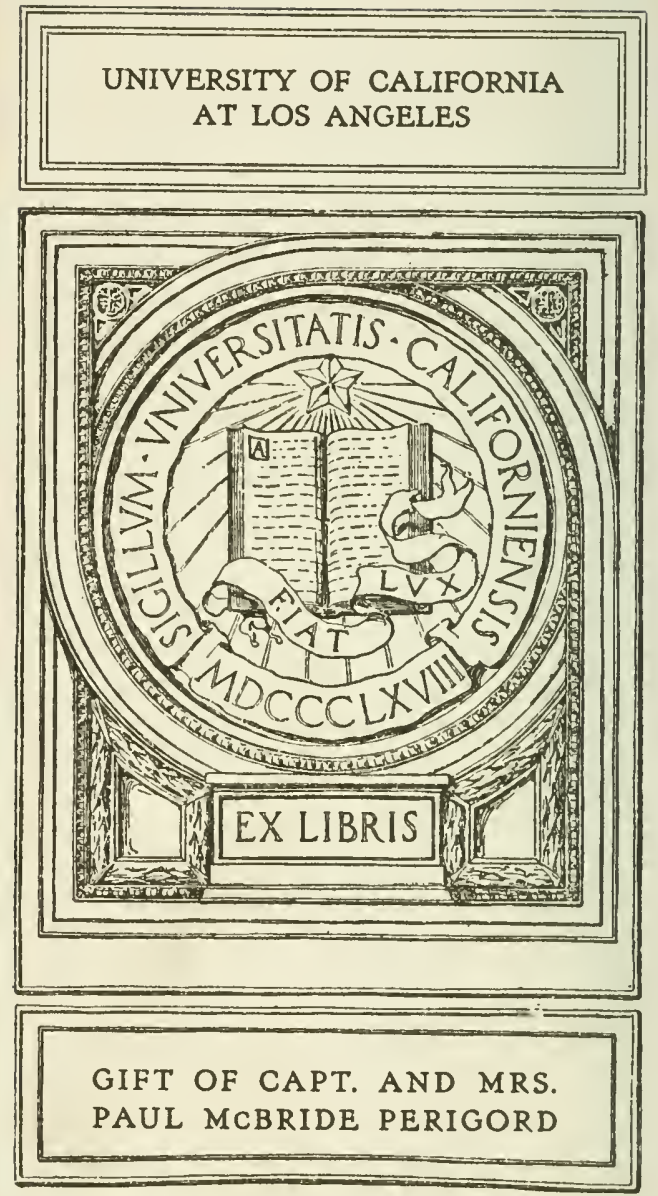
<smiles>C=C</smiles> 
THE LAND AND ITS PROBLEMS 


\section{A NEW SERIES ON ECONOMICS \\ Crown svo}

THE following are the first of a set of volumes dealing with the fundamental principles and method of Political Economy in a concise and simple manner.

Their object is to explain the essential facts and theories of that science, and its important bearing upon human welfare in language not too technical or abstract, and thereby to stimulate an interest in economic doctrine, and to foster a study of the problems of wealth and poverty, production and consumption, and of the causes which govern the welfare of nations.

The series isedited by G. ARmitage-Smith, D.Lit., M.A.

A PRIMER OF NATIONAL FINANCE.

BY HENRY HiGGS, C.B.

LABOUR ORGANIZATION.

By GeORGE O'Brien, Litt. D.

FOREIGN TRADE.

By W. Henderson Pringle, M.A., LL.B.

WEALTH : ITS PRODUCTION \& DISTRIBUTION.

By A. W. KirkaldY, M.A., B.Litt. Oxon.

THE LAND AND ITS PROBLEMS.

By Christopher Turnor. 


\title{
THE LAND AND ITS PROBLEMS
}

\author{
BY \\ CHRISTOPHER TURNOR
}

WITH TEN DIAGRAMS

METHUEN \& CO. LTD. 36 ESSEX STREET W.G.

LONDON 
Fust Published in 1921 


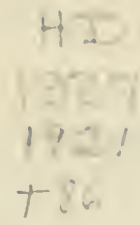

\section{PREFACE}

W

E have been a land-ignorant race-and yet we are all dependent upon the land, the townsman as well as the countryman. It is not a question requiring the consideration and the votes of only the rural population; the urban population holds the predominant voting power. Therefore a sound land policy can only be hoped for when, in the first place, the townsman understands something about the land, and, secondly, when he is capable of thinking correctly about it. So this book is not intended in any way as a technical treatise on Agriculture; rather is the object to lay stress upon the vast importance of Land as our greatest Imperial and National asset, and to show that if the permanent consolidation of the Empire is to be achieved this can only be effected by giving the necessary care and thought to the development of our land resources. It is thenessential for this purpose to consider the land of the Empire as a whole, rather than piecemeal in its different geographical parts. And inseparably interwoven with the Land problem is the human side-the question of the cultivator of the soil and the conditions under which he should live.

This great twofold problem of the land and the people has never really received the consideration it should by the people of the Anglo-Saxon race. And herein lies the root of the evil.

In other civilized countries the townspeople realize 
much more definitely than we do their direct dependence upon the land, because for many years it has been customary to give the rising generations instruction concerning land, just as instruction in history or mathematics is given.

One of the aims of this book is to show the national importance of maintaining the area of land under the plough, and of increasing that area where it is wise to do so.

Another aim is to lay stress upon the national and social importance of maintaining the number of small holdings (i.e. farms of fifty acres and under) and upon the need of improving the living and business conditions of the smallholders.

It is not suggested for one moment that the United Kingdom should become entirely a country of small holdings, nor is it suggested that all grass land should be ploughed up.

There must always be a large proportion of grass land ; but this should be well farmed, and put to the best economic use, which it is not at the present moment.

The one hope of the writer of this book is that it may serve in some small degree to interest people, not definitely connected with the land, in the land problem; and induce them as voters to insist upon our land being put to its fullest national use, that the cultivators of the land shall live under the best possible conditions, and that their children be given educational opportunities equal to those enjoyed by the town child.

Since Chapter IX was written, the Government has repealed Part I of the Agriculture Act.

C. T. 


\section{CONTENTS}

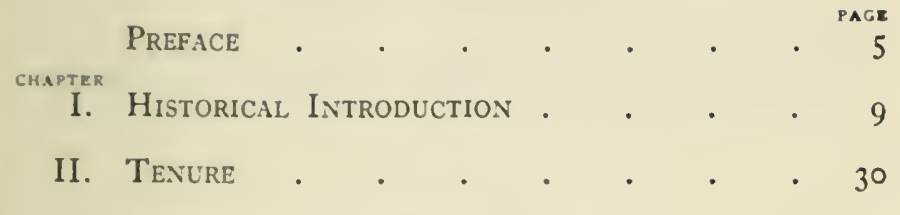

III. Agricultural Dramatis Personfe • • 41

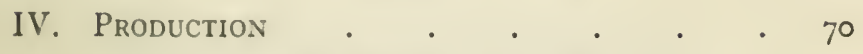

V. The System and Methods of Production in the United Kingdom • • • • $9 \mathrm{I}$

VI. Small and Large Holdings • • . 112

VII. Farm Accounts and Demonstration Farmb 132 ViII. On 'Taking Up an Agricultural Career • 14 I IX. The Objective in Production and Future DeVlopments . . . . . 153

X. Imperial Considerations . • . . 177

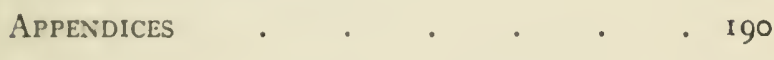
INDEX . . . . . . 251 



\section{THE LAND \\ AND ITS PROBLEMS}

CHAPTER I

\section{HISTORICAL INTRODUCTION}

THE review of the history of agricultural development in the United Kingdom must needs be

1 brief in a book of this size ; it is a subject full of interest and of importance, but we shall have to confine ourselves to salient features and to that side of the story which relates to efforts to increase the production of food from the soil.

For it is a matter of fundamental importance that the land of the country shall produce the economic maximum amount of food for its people-the word " economic" is here used in its widest sense, and includes not only financial considerations, but also the question of the conditions under which the producers of primary wealth live. For where the living conditions of the cultivators are bad, production is uneconomic from the national point of view.

In this chapter I shall give first a brief sketch of the state of agriculture in Britain for the past two thousand 
years, and, secondly, some account of the condition of the cultivators.

The degree of civilization of a race of people is very clearly indicated by their attitude towards the land; primitive man regarded the land solely as a happy hunting ground; he lived by what he could kill. In the next stage we find man beginning to realize the advantages of keeping domestic animals; but for many centuries, in northern countries, these domestic animals were of a very poor type and obtained their living entirely from the natural produce of the land, and it was a precarious living in winter. Winter feeding of stock, as we understand it now, is a comparatively recent practice.

It is only in what may be termed the third stage of civilization that we find our forbears beginning to develop husbandry; then agriculture, i.e. the actual cultivation of the land, had its birth, and it remained for a long time in a very elementary state in northern Europe and England.

Modern agriculture, in which the use of machinery and artificials play so prominent a part, may be said to date from 1837 , and the highly intensive cultivation of the soil was not attempted until much later in the century.

\section{PRE-ROMAN PERIOD}

The first mention of British agriculture known in history is to be found in the story of the travels of Pytheas, the enterprising Greek who sailed round the western coast of Europe and apparently got as far north as Norway.

$\mathrm{He}$ visited various points on the English coast about the middle of the fourth century B.C., and conceived an 
exaggerated idea of the size of our islands, thinking that he was visiting the fringe of a vast continent. He only coasted along the eastern and southern sides of England; and he places on record that he found the natives growing wheat, and on account of the uncertain climate their method of harvesting was to strip the ears and thresh them under covered sheds. He does not refer to the growing of any other crops, so that we cannot say what their methods of agriculture were; but in view of their growing wheat and handling it in that way it is safe to assume that they had reached a certain stage of development in agriculture.

The only other thing he mentions is a drink that seems to resemble strangely our modern beer !

The next visitor to Britain was the Roman Posidonious, in the first century before Christ, and he refers to agriculture in much the same terms as Pytheas.

\section{THE ROMAN PERIOD}

During the Roman occupation of Great Britain there was quite an advanced agriculture, although we do not know what area of land was under cultivation; we know that they grew wheat and that they harvested it in an up-to-date way, stripping off the ears of wheat in the American fashion and when necessary drying the grain on heated stone or concrete floors. This treatment of the wheat crop means that the straw is lost-a loss which we could not afford, in these days, in England.

Even-what is more remarkable-lucerne, or alfalfa, was grown; it is only during the last few years that our farmers have again taken to this valuable crop.

The Romans fully understood and utilized the power possessed by leguminous crops of increasing the richness 
of the soil. A passage in Pliny advises the farmer to "sow next year's wheat crop in the field where he has just gathered his beans, vetches, lupins, or such other crop as enriches the soil."

The chief plants of the leguminous order, besides those mentioned above, are peas, clovers and lucerne. Of these lucerne is the plant that endures the longest; a field may remain under lucerne for from five to nine years in England, and in some other countries for an almost unlimited time.

The Romans in their turn acquired their knowledge of agriculture from the ancient Egyptians, who understood the value of leguminous crops and of rotation of crops at a very early age.

A very advanced agriculture was practised in the Mediterranean countries from prehistoric times; this development was the natural result of a dense population living on fertile land limited in area; high cultivation was essential in order to feed the dense population.

It is interesting to note that, in quite another part of the world, the Chinese understood the use of leguminous plants as early as rooo B.C.

This knowledge of the use of leguminous plants, and of the immense value of the rotation of crops, is one of the definite landmarks in the development of agriculture ; and the recovery of this knowledge is of comparatively recent date in England.

\section{THE FIFTH TO THE SEVENTEENTH CENTURIES}

When the Roman occupation of England ended, all attempt at agriculture ceased. Little was done even in the Middle Ages, which was indeed a period of darkness as far as the cultivation of the land was concerned. 
Meat in one form or another remained the staple diet for centuries, presumably salted meat for winter use ; for, with a complete absence of cultivated foodstuffs, live stock in winter must have been too thin to be worth killing-and it could only have been the breeding stock which would be left to face the winter as best they could.

In the eleventh century agriculture began to revive in Spain under the influence of the Saracens, who were decidedly good cultivators, and who set about building up the great primary industry that the inroads of the Goths and Vandals had so completely wiped out. But this revival did not reach the British Isles until many centuries had elapsed. Even at the end of the reign of Henry VIII salads and edible roots were not grown, and on one occasion when Queen Catherine had set her heart upon a salad she had to send to Holland for it! Wheat was a luxury; the poorer classes had to content themselves with oats, barley, or rye, of which gradually increasing quantities were grown.

\section{SHEEP versus CATTLE}

Up to nearly the end of the sixteenth century it may be said that cattle and sheep grazing were the mainstay of the landowner and farmer. As English wool was in great demand on the Continent, and sheep were more profitable than cattle, the landowners endeavoured to own as large flocks as possible; at various periods they pushed this policy so far that a serious shortage of beef resulted. In the fourteenth century we find the Government so much perturbed at the situation that legislation was introduced to encourage cattle-breeding and lessen the predominance of sheep; this took the somewhat quaint form of giving cattle the precedence over sheep. 
Apparently, however, sheep did not take this lowering in the social scale very much to heart, for in 1488 a very serious state of affairs is recorded.

"Where in some towns," says the Statute $4^{\text {th }}$ Henry VII, "two hundred persons lived and were occupied with their lawful labours, now there are occupied two or three herdsmen and the residue fall into idleness."

Therefore it was enacted that farms with 20 acres under tillage must be upheld, under a penalty of half the profits to be forfeited to the King.

This failed to improve the situation and in 1534 a new Act was tried, "Sheep being come in to a few persons' hands." Single persons owned flocks of sheep ranging in number from four thousand up to even twenty-four thousand. A monopoly in wool existed, and the price thereof in consequence had risen greatly. Therefore a penalty was imposed upon everyone who kept over two thousand sheep, and no person was to take more than two tenantries of husbandry.

\section{GRASS versus ARABLE}

When Elizabeth came to the throne the case of sheep versus cattle had more or less settled itself, and we find a new basis to the legislation. The aim was to secure a larger area of plough land and to reduce the area under grass; and one of the most drastic measures ever passed was that of the 39th Elizabeth (I 597) enacting that all land made pasture since the Ist Elizabeth shall again be converted to tillage, and that no existing arable shall be converted into pasture.

In view of the measures taken by the Government during the Great War to induce British farmers to keep 
a larger area under the plough, this Elizabethan Act is of great interest.

It is abundantly clear from history that the British farmer has by disposition a natural inclination towards grass land farming and to keep his arable area as small as possible-this quite apart from the fact that grass grows better in the British Isles than almost anywhere else in Europe; and in some parts of the country the heavy rainfall makes it quite legitimately the predominating crop.

Whatever the practical results from the Elizabethan Law they are not recorded-the measure must have had a certain effect in increasing arable cultivation, but little real progress in agriculture in England can be noted until early in the eighteenth century. In Scotland, even in the rich southern counties, agriculture was at a lower ebb and later in developing than in England.

Still, signs of the coming developments can be found ; for instance, one of the earliest references to the growing of turnips and clover as sheep-food is by Houghton in I68I. And he bears testimony to the fact that arable land produces more food for man and beast than grass land. "Ten acres sown with turnips, clover, etc., will feed as many sheep as one hundred acres would before have done."

In this he indicates the direction future developments should take, and he thus sets up one of the landmarks in our agricultural history.

\section{FROM THE EIGHTEENTH CENTURY}

Jethro Tull was one of the first of the pioncers in "modern" agriculture; in I701 he first began to drill whea: and turnips; he grew turnips as one of his 
standard crops, and adopted the system of horse hoeing, thus largely supplanting the old and more laborious system of hand hoeing. Before the drill was invented, which enabled the sowing of seed in evenly spaced straight lines, all sowing was done by hand-broadcast, which made horse hoeing impossible. But Jethro Tull was full thirty years in advance of his times and had to face the opposition and even hostility of the farming community.

The use of turnips must have spread slowly, for the writer possesses a silver cup which was given in 1769 as a prize for "the best six acres of turnips compleatly hoed "; this in the North Riding of Yorkshire, so that there at all events turnips were regarded as a new crop to be encouraged by prizes as late as 1769 .

After Jethro Tull the two outstanding agricultural pioneers are Coke of Norfolk, who worked for the improvement of agriculture in all its branches, and Bakewell, who concentrated his attention upon the improvement of our live stock. They did their great work towards the end of the eighteenth century; but a marked and general improvement in our agriculture began to show itself about 1730 .

By the end of the eighteenth century the rotation of crops was universally practised; this involved the full use of leguminous plants.

Although this is so, the functions of the leguminous plants were by no means fully understood; and the most valuable plant of this order, lucerne or alfalfa, was little used.

We have seen that it was grown in Roman times in England, but any material increase in the area used for this crop did not take place until the end of the nineteenth and beginning of the twentieth century. The areas 
devoted to lucerne being in $1 \$ 90$ i $\$, 000$ acres, in 1910 28,000 acres.

As has been stated the great use of the leguminous plants is that they put nitrogen into the soil in the least expensive manner ; farm-yard manure also provides a certain amount of nitrogen and of phosphates and potash.

Science has placed these substances at the disposal of the farmer in another form-in that of artificial or chemical manures, but the use of these should be complementary ; they do not replace the use of farmyard manure and leguminous plants.

The progress begun in $173^{\circ}$ was continuous, and carried British agriculture up to its zenith (in the middle of the nineteenth century) when the yield from our soil far exceeded that of any other country in terms per acre. Foreign agriculturists flocked to England, to study our methods, up to about 1860 ; then a change began to be noticed.

Other countries, having benefited by our experience, then began not only to catch us up but to surpass us ; they developed a superior organization of the industry and they made far greater and more intelligent use of the discuveries of scientists, particularly in regard to the application of chemical manures.

Finally it is only in the quality of our pedigree live stock that we have been able to maintain our supremacy; and even in the handling of our live stock there is much room for improvement.

In 1875 the great agricultural depression began, due to the competition of the new world, and there resulted a disastrously retrograde movement in our primary industry; production decreased and land even went out of cultivation, farmers went bankrupt, and the 
industry lost $f, I, 000,000,000$ of its capital. Yet, during this period, in continental countries agriculture was forging steadily ahead. Here I am concerned only with the bare statement of the fact.

It was not until 1904 that definite signs of improvement in the agricultural situation could be seen, and from that time until the Great IVar prices were working slowly upward and farmers were better off. But in spite of increasing prices there was little corresponding increase in production from the soil.

\section{WHEAT}

Wheat is or should be the basic crop in arable farming, and from the national point of view it is of such importance that a paragraph or two must now be devoted to it.

From I600 onwards, more and more wheat was produced and the yield of wheat per acre gradually increased.

In the Middle Ages the average yield of wheat per acre was very low-about that of Australia to-day, i.e. some 12 bushels per acre. By 1800 it had risen to an average of 20 bushels, and for the nineteenth century the yield was about 30 bushels, and this is our present average.

It is hard for us to realize from our own experience in regard to growing wheat in England that, at one period, she was a wheat-exporting country-in fact for nearly a century, between 1688 and 1760 , the export was considerable in some years.

After 1760 we exported very little wheat, and from i $8_{40}$ our imports increased steadily. In 1840 we were growing 


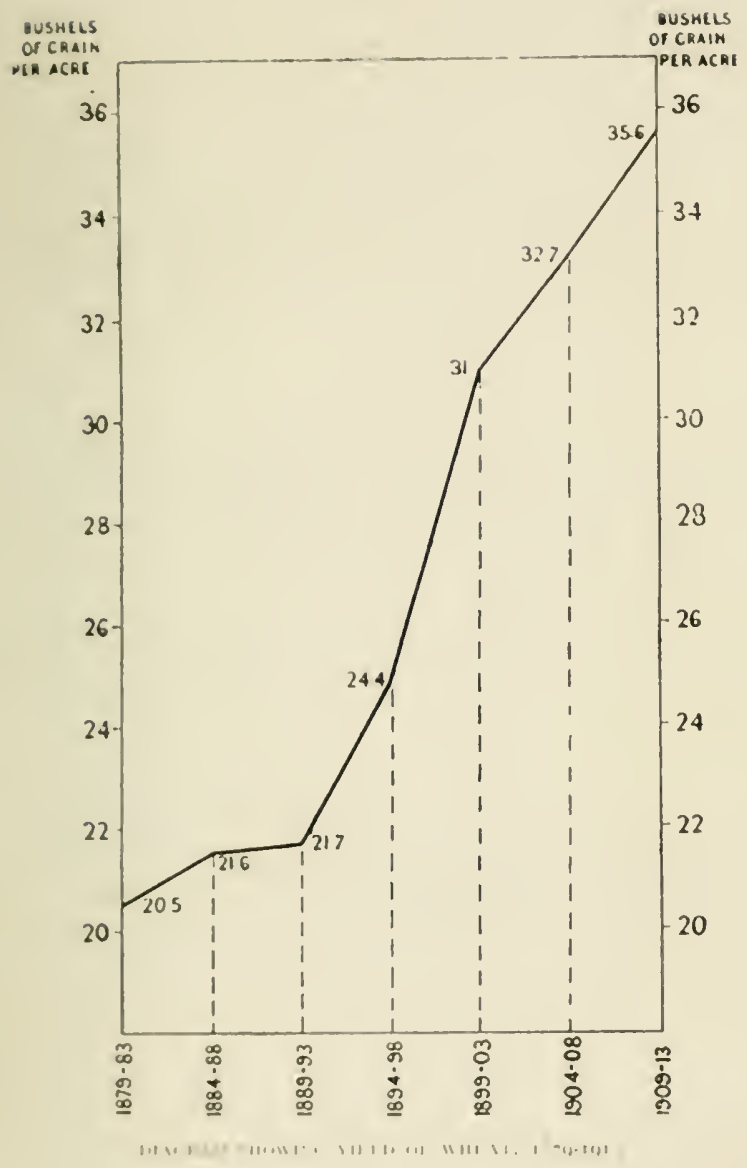



home wheat for about twenty-four million people; this was our high-water mark; after that not only did our wheat production fail to keep pace with the increase in our population, but it was the crop that suffered most and was most reduced owing to the effects of the depression.

In 1914 we were only growing sufticient wheat to meet the needs of about eight million people, or onefifth of our population.

\section{THE CULTIVATOR}

So far we have been considering the actual cultivation of the land; and now, if we turn our attention to the condition of the people living on and by the land, we can trace an evolution that has not been altogether good especially from the labourcr's point of view. Under a primitive society everyone had access to land for what that was worth ; it was an open run for everyone's live stock. As population increased most nations seem to have gone through a period of communistic ownership of lands. A certain area was recognized as belonging to a commune and it was divided up amongst the members as best suited the needs of the commune; or, if it was not actually divided up, the individuals had certain rights of pasturage on the common land. 'This system survived into Feudal times in a greater or less degree in different countries.

In Russia it obtained up to the great revolution, and apparently still exists; there the "Mir" or communal council divided the common lands amongst the members of the community at certain definite periods or when need arose. On these occasions there was no chairman of the meeting, all the members of the Mir talked, sometimes all at once; and out of the 
seeming confusion, in the end, an allocation of the land evolved itself that apparently gave satisfaction to those concerned.

\section{ENCLOSURE}

In England after the Norman conquest most of the land was "common land"-the hedged-in farm as we know it did not exist-and this common land or common or open field system of tenure continued, though in ever diminishing extent, well into the nineteenth century.

High farming was impossible under this system; there was nothing for it but to enclose this land, and I believe the carlicst case of legal enclosure was at the end of the thirteenth century. This process continued through the succeeding centuries, at a gradually accelerating rate, till all land worth enclosing was enclosed.

The enclosing of the open farm, and doing away with the common land system of farming, was all to the good. The enclosing of wild and uncultivated land, and bringing it under cultivation, was also beneficial from every point of view. But alas there was much enclosure which was far from being sound from the national point of view, and that was the enclosing of common lands over which the smallholders and labourers had common rights, and valuable rights they were.

To-day some of these commons still survive, but they are now rather public pleasure grounds than the land of the commoners-a class which, in the old sense of the term, is practically extinct. In the old days the common lands were for the use of the commoners, i.e. those who had common rights, the right to pasture their sheep and geese and even cows on the common lands. 
Also a certain portion was given up to tillage. A large proportion of the labouring men possessed common rights which were of the utmost value to them. One has only to study a pre-I790 labourer's family budget to see how much better and more varied was the fare, as compared with the labourer of later years who had been deprived of his common rights.

The hundred years between $175^{\circ}$ and $1 S_{5}^{\circ}$ was the great period of Enclosure Acts : between $179^{\circ}$ and $185^{\circ}$ some $7,000,000$ acres were enclosed.

Not only was the enclosing of common land a great injustice to the labouring class, it was unsound from the social and political points of view; as stated above the daily fare of the labourer was adversely affected and all direct and independent interest in the land was removed, and the agricultural labourer was forced into the ranks of the landless proletariat.

We have not even yet come to the end of the effects of this disastrous policy.

The advocates of enclosure ever insisted upon the fact that "Enclosures secured the better cultivation of the land," and this is quite true ; only the land should have been enclosed and secured to the commoners themselies, and the large neighbouring landowners should not have been allowed to get possession of it as they actually did owing to the fact that the new small owners, not being able to afford the cost of fencing, etc., had to sell out. It is noteworthy that in Prussia and in certain other countrics enclosure on a large scale took place; but the common land was turned into small holdings, of which the late commoners became the occupying owncrs to the great benefit of the community gencrally.

In some parts of England certain villages have still 
the "cow pasture," often the much circumscribed remains of the old common land; a certain number of the villagers have a right to pasture a cow apiece in the common field. In view of the present shortage of milk it would be well to increase the area of common cow pasture, and so encourage the cottager to keep a cow or two. Unfortunately with land changing hands frequently, as it does now, these useful cow pastures tend to disappear.

We have here to place on record the fact that one bad feature of the later development of agriculture has been the divorce of the labourer from a direct interest in the land.

From time to time some more far-seeing individual would draw attention to this serious evil. A little more than one hundred years ago Lord Winchelsea urged that at least a good garden should go with every cottage, and he sct an cxample which was followed by many of the great landowners. But this only touched the fringe of the problem; it did little to undo the mischief done, and it was not until the Small Holdings Act of 1908 was passed that an effort on a large scale was made to give again a direct interest in the land to the labourer.

\section{HOUSING}

$\mathrm{Up}$ to $\mathrm{I} 837$ the housing conditions of the country labourer were very bad; from that date onwards there has been steady improvement, but even to-day there is a serious shortage of cottages and many of the existing cottages are not fit for a man with a family.

It should be remembered in regard to housing in the country, that bad conditions there are not quite as serious as they are in the town; the inhabitants are 
more out of doors and follow healthier occupations. Before the great depression the cottages were much more generally in the hands of the landowner-the labourer held his cottage from the owner and not from the tenant farmer. To-day, as a rule, all the cottages belonging to the farm are let with the farm and the labourer holds his cottage at the will of the farmer who employs him-this is technically the "tied cottage"-and he may suffer hardship in consequence. The great need is for "free" cottages in our villages and near to the schools.

Rentals for cottages have always been so low that cottage building has never been a remunerative proposition. And it is very hard to see how the agricultural labourer will ever be able to pay an economic rental for his cottage.

\section{WAGES}

Agricultural wages have always been low. For generations after the Norman Conquest the labourer was not paid any wage at all-he had to work in return for the protection afforded to him by his overlord, while he got his subsistence from the land to which he had right of access, or from certain payments in kind.

By the fourteenth century cash wages were becoming fairly general ; and it is interesting to note that the period of lighest wages in the whole history of our agriculture was during the fifteenth century, when the average cash wage was equivalent to 2.4 s. per week in the money value terms of 1914. This happy state of affairs for the labourer was chiefly due to the shortage of labour which was created by the Black Death.

In the sixteenth century wages dropped again, and there was little improvement until about 150 years ago, when an upward tendency began to assert itself. 
In 1770 wages were about $7 \mathrm{~s}$. per week in cash, plus certain payments in kind; but we must remember that up to this date, and the complete enclosure of the common land, labourers were able to supplement their wages considerably from the land they had access to.

By $185^{\circ}$ the average was ros. a week in cash, plus allowances; and in I9I4 the average for England had risen to about $\mathrm{r} 6 \mathrm{~s}$. in cash and allowances-bacon, milk, potatoes-valued at about $4 \mathrm{~s}$.

The cash payment varied considerably in the different parts of England ; in Lincolnshire it was 18 s., in Yorkshire and the northern counties 20s. and 218 . It was lowest in the southern counties, only $12 \mathrm{~s}$. to $14 \mathrm{~s}$. in some places.

Several years before the war this low rate of pay had begun to weigh upon the national conscience, and many farmers themselves realized that wages should be higher ; there was a general consensus of opinion that 20s. a week in cash should be the minimum wage.

Then came the war, and in 19r6 the Agricultural Wage Boards were established; the cost of living had already increased so much that there could be no question of a 20s. a week minimum-it required double that to meet more or less the increased cost of living.

\section{RATE OF WAGE PER ACRE}

It is, however, curious to note that although the rate of wage per week remained so constantly low, yet in relation to rental, and ratio to the gross output of the farm, it rose rapidly.

The output was increasing, so that shrinkage of output was not the cause, nor was it owing to variation in rent, nor, as we have seen, to an increased wage. It is 
suggested that the main cause is that the output per labourer has greatly lessened; this is true to a certain extent-indeed, since the Great War to a marked extentbut I cannot regard it as the main cause, which I think will be found to lie in the fact that in times of prosperity more and more labour per farm was employed.

In other words, one of the factors of agricultural progress being that a greater amount of labour was bestowed upon the land, the wage bill increased in consequence.

The following figures illustrate the point.

In $\mathrm{ISO}_{5}$ on a farm chiefly arable, rented at $f_{\mathrm{I}}$ per acre, the rate of wages per acre was only 5 s. In another case where the farmer paid $£ 200$ a year for his farm his labour bill was only $f_{5} 5^{S}$ per annum.

During the last half of the nineteenth century the wage bill in terms per acre was roughly taken to be equal to the rental per acre, though as a matter of fact it was generally a few shillings per acre more than the rental. From a slightly different point of view the accounts of a Suffolk farm of 600 acres show that for the period I $839-43$ the ratio of cost of labour to gross profits was 49 per cent ; $186_{3}-7,54$ per cent ; $1871-5,59$ per cent ; I $890-4$, I 33 per cent.

The enormous increase in the ratio for the last period was chiefly duc to the low prices prevailing in the great depression.

To-day (in 1920) the labour bill would generally average at least four times the rental on an arable farm.

\section{SOCIAL STATUS}

In early Feudal times there was no clear distinction between the farmer and the labourer; there was the 
landowner - the overlord-and all others occupied upon the land worked for him; they looked to him for protection and gave their services to him in return. The times were unsettled; landowners spent most of their time in fighting, rather than in the development of their land which they held direct from the Crown. They were obliged to give their services to the King when called upon to do so.

As time went on, and population increased, the individual farmer began to develop. Doubtless capacity counted then as it does now, and the capable man would have the larger area of land and employ men to work for him.

Before 1400 the farmer did not pay rental (as we understand the term) to the landowner; he gave the latter one half of the annual produce from his farm. This is the Metayer system, which rules to this day in Italy and parts of France. But in practice this system does not work well ; it entails much work for the landowner's agent who has to see to the handling and selling of great quantities of produce, and who also has to exercise strict supervision to see that the farmer does not sell produce before the division has been made.

From 1400 on, it became increasingly the custom for the landowner to require his tenants to pay rent in cash. Although the system of landlord and tenant gradually grew up in Great Britain, there was also a steady growth of the occupying owner-the sturdy yeoman who was such a valuable factor in the rural community. At the end of the seventeenth century there were 160,000 occupying owners, constituting well over 50 per cent of the total occupiers of land.

From that date began the decline in occupying ownership; merchants becoming rich liked to buy land in the 
country, but the process was slow up to the Napoleonic wars. One of the most baneful effects of these wars was the practical extinction of the yeoman class. Carried away by the high price of wheat, the small owners were tempted to speculate and to live extravagantly; in consequence they were obliged to sell to rich townsmen, and to the great landowners of England who at this period from one cause or another had become possessed of great wealth. There was little opportunity for foreign investment and the chief object was to buy more land-to lay farm to farm; so the great landowners became greater, and the land was vested in fewer hands than ever before in the history of England and the class of tenant farmers increased in consequence.

It is worthy of note that throughout the Feudal times, and until dispossessed by IIenry VIII, the Church was a great landowner, and as a rule this land was the best cultivated in the kingdom; this was largely because it was less affected by the unsettled conditions than the the land of the great barons who gave much of their time to fighting for the King.

The following are the chief points which emerge from a study of our agricultural history for the last thousand years.

(I) That prior to the nineteenth century agricultural labourers had a more direct interest in the land owing to the fact that considerable numbers had access to common lands.

(2) That the proportion of occupying owners was higher before 1800 than it has been since; the reduction in the number of owners was largely due to the effects of the Napoleonic wars.

(3) That State interference in agriculture is no new 
feature; and that at various periods during the last 600 years the Government has attempted to reduce the area under grass and to increase the area under the plough.

(4) That the British farmer has always resented such interference, and has often put up a passive but effective resistance to it.

(5) That the development in British agriculture is of comparatively recent date.

(6) That in the main, development and improvements in agriculture have not been evolved by the farmers themselves, but by a few outstanding individuals-or in recent years by the action of the Government, e.g. in creating a system of agricultural education.

The great agricultural societies have played an important part at times, but these societies are not "farmers" " societies pure and simple. Landowners have always taken a leading part. In regard to State interference it has sorrowfully to be admitted that in this country it has been on the whole singularly unsuccessful, largely because we have had an official personnel not well qualified to deal with complicated land questions, and even more because we have had no fixed and carefully thought out agricultural policy to guide the official administration.

In strong contrast is the result of Government action in such countries as Denmark and Germany ; there for many years there has been a definite agricultural policy recognized as right and sound by all partics, and the State has assisted the agriculturists (and in turn it has been assisted by them) to bring that policy to fruition to the benefit of the whole nation.

The succeeding chapters will deal with the more 
recent phases of agriculture subsequent to the Napoleonic wars. ${ }^{1}$

1 For anyone wishing to read up the history of English Agriculture and its evolution let me recommend Mr. Curtler's interestingly written Shout Hislory of English Agricullure (Clarendon Press, Oxford); Mr. Prothero's Agricullure, Past and Present. And for an exhaustive history of the agricultural labourer. A History of the Euglish Agricultural Labourer, by Hasbach, and The Village Labourer, $1,60-1832$, Hammond. For a full history of Enclosure in all its forms, The English Pcasantry and the Enclosure of Common Ficlds, Slater. Coke of Norfolk (John Lane, Bodley Head) is a most interesting book in two volumes and gives a good picture of what was going on agriculturally at the end of the eightecnth century. For a short and interesting history of economics the Principles of Political Economy by List is strongly recommended : it deals impartially with the questions of frec trade and protec. tion, and it is a book that every student should read. 


\section{CHAPTER II}

\section{TENURE}

TEGALLY speaking there are many varieties of tenure, some being survivals of the complicated systems of the Saxon and Middle Ages, but in this chapter the word tenure is meant to embrace only two main systems under which land is occupied to-dayoccupying ownership and occupying tenancy. Whereas, in most countries of the world occupying ownership forms the basis of the system of tenure, with us the bulk of the land is held by occupying tenants renting their farms from the owners of the land. At least this was true up to the outbreak of the Great War ; but during the war, and since, there has been a rapid breaking up of the great estates and a consequent increase in the number of smaller owners. In many cases the farmers have bought their own farms ; in others, unfortunately, the land has been bought by speculators.

The chief reason for this selling of large estates is that owing to the increased taxation and the greatly enhanced cost of buildings, repairs, and general maintenance the landowner's income is so scriously reduced that he is forced to sell. Even before the war the landowner received at the outside only 2 per cent interest on capital invested in land and buildings; and now he can sell out and reinvest at 5 per cent or 6 per cent. In all countries the rate of interest received from capital invested in land 
(including equipment), as distinct from capital invested in the working of the farm, is lower than from other forms of investment, but nowhere is this so strikingly the case as in England.

During the past century, and up to 1914 , statistics show us that $S S$ per cent of the occupiers of agricultural land were tenants, and only 12 per cent occupying owners. So that our system was one under which one man owned the land while another cultivated it.

The advocates of the tenancy system maintain that it is an excellent plan for the man unskilled in cultivation - the landowner - to provide the capital, in the form of land, for the practical man-the farmer-to work; and it is undoubtedly pleasing to the practical man to get capital below the market rate of interest, but it is uneconomic and therefore in the long run unsound. Above all, it is not conducive to the highest effort on the part of the farmer.

It is interesting to note that in Denmark sixty or seventy years ago the proportion of occupying owners to tenants was precisely the same as with us at the prescnt time. But when the reform of agriculture was undertaken in that country, acting upon a definite policy in which the agriculturists and Government worked in complete accord, the first object was to reduce the number of tenants and to increase the number of occupying owners. So that to-day in Denmark the position is reversed, there are only 12 per cent tenants and 88 per cent occupying owners. It is very generally held in other countries that occupying ownership is the basis of sound agricultural conditions; and there can be no question that the countries in which agriculture has reached its highest point of development and organization have occupying ownership as the dominant form of tenure. 


\section{THE LAND AND ITS PROBLEMS}

It is not implied inat ownership in itself is the only cause of a high state of agriculture, but it is seen to be a constant and important factor.

Considering the problem solely as it affects the United Kingdom the questions of interest are :-

(I) Why did tenancy become practically the universal form of tenure?

(2) Has this form of tenure been satisfactory from the economic point of view ?

(3) Are changes necessary to meet the needs of the present and, as far as can be foreseen, future conditions?

In regard to the first point, causes other than economic comc in and play their part.

As already stated, one effect of the Napoleonic wars was to reduce the number of small owners and to increase the number of tenants. The large landowners and rich townsmen were buying out the small owners, and if a man wanted a farm he had to rent one.

If during the last forty or fifty years we have neglected cereal growing, in the early decades of the nineteenth century we overdid it; everything was sacrificed to growing wheat. Little wheat could be imported and the required amount had to be grown at home; prices rose till few farmers could resist the temptation of going in for wheat growing, and much land that was not suitable for wheat was nevertheless planted with it. Farmers gambled in wheat, with the result that many of the smaller owners went under and were obliged to sell their land. Where the tenant failed, he simply went out and another took his place.

Another cause was the enclosure of common fields; this process crowded out the small owner, his land 
became incorporated in the large surrounding estates and was naturally let out to tenants.

A still further reason for the development of tenancy was the existence of a great land hunger amongst the rich; land brought with it social prestige and political power. And the amenities of ownership of land must not be overlooked, for this side of the question was more pronounced in England than in most other countries. For years the landowners were so wealthy (often quite apart from their capital in land) that they could afford to consider landowning as an amenity rather than as their main source of income. 'Then as time went on the English landowner developed a great fondness for shooting and often, alas! "sport had it" to the disadvantage of agriculture. There is no doubt that the excessive development of sport could not have taken place under a system of small ownership.

Again, landowners did not wish to farm large areas themselves and therefore the only course open to them was to let it to tenants. In those days tenants lived up to their contracts, and painted and kept in repair their houses and buildings. So that the landowner's outgoings for the maintenance of his farms were light as compared with the period subsequent to the great depression of 1875 .

The increase in tenancy, for the reasons given above, just happened to coincide with a period of great agricultural progress ; it was not deliberately developed because considered to be the system of tenure best suited to progressive agriculture, nor did it come about as the result of the working of any immutable law of economy.

'The system at its best undoubtedly suited the temperament of our people, and for the time being it saved them 
the bother of formulating a national agricultural policy based on sound principles. As a nation we abhor problems and finding their solution!

From I 820 to 1870 , when the farmers were prosperous and landowners also had plenty of money, the tenancy system was a pleasant one to both parties. The landowner took pleasure in putting up good houses and fine farm buildings, and the farmers took pride in keeping them in good order. The relationship was generally a most cordial one.

Coming to the second question, has this system of tenure been good for the nation from the economic point of view? There is a very general tendency to accept as good any system that is universal. "It would not exist if it did not suit the characteristics of the people and the country." Or "It exists as the result of the workings of the Laws of Economy." Or, putting it in a somewhat cruder form, "The farmers like it!"

But it is necessary to go somewhat deeper into the question if sound conclusions are to be arrived at. In the first place, all the laws of economy are not immutable as are the laws of nature; man by taking thought can alter conditions, and so alter the economic situation that the application of these laws is affected. For instance, the common or open field system of cultivation was undoubtedly uneconomic, but that did not justify the taking of the land from the people who owned it! The uneconomic features could have been removed and at the same time the rights of the owners confirmed-to the great advantage of the nation's economy.

The first consideration that strikes the observer is that not only is the land of England owned by one set of men and cultivated by another, but that the set of 
men who own the land are passive partners in the industry of agriculture-mere rent receivers.

Though many owners depend upon the rental from the land for their subsistence, few depend upon the actual cultivation of the land for any considerable portion of their income. In other words, English landowners do not derive their income direct from the land as a result of their own efforts-they obtain it vicariously. 'This does not mean that the owner is in any way a parasite, for in the past he has generously expended his capital to put the land into a condition for the farmer to use. And in the years of agricultural depression he came to the farmer's assistance and bore his full share of the loss. But it does mean that the farmers do not regard the owner as one of themselves, or as directly interested in the cultivation of the land.

For one important class of the agricultural community to be so little interested in the actual cultivation of the soil is certainly an evil that has helped to bring about unsound conditions. The contrast in the case of the foreign owner is striking; he farms as a rule the larger part of his estate, and he farms it on a commercial basis and so successfully that he is regarded as a farmer by the farmers themselves. More than this, he is regarded as the leader of agriculture and the natural person to represent the farming class in the legislature.

In support of the system of tenancy, it is said that it is much more sound economically for the farmer to rent his land, and keep all his capital for working capital, rather than to sink it in the purchase of the land itself. 'This is incontrovertible, and no one wishes to controvert it; but if land banks existed in this country as they do on the Continent the tenant would be able to buy his farm under a system of annual instalments, without 
encroaching upon his working capital. Under this system the farmer sinks little or no capital in the purchase of land, and long experience has shown that annual payments do not work out at a higher figure than the farm can stand economically; so this argument against purchase falls to the ground. Again, it is pointed out that the small owners (and large owners also) often are weighed down by mortgages and finally have to quitbut that is not an argument against ownership, it is an argument against mortgages! The permanent mortgage is the most unsound form in which an owner can borrow money. That was clearly recognized one hundred years ago by landowners on the Continent, and as a result the system of loans with sinking fund was established.

Under the mortgage system, if the value of the land drops, the occupying owner finds himself in difficulties, and often he cannot afford to keep his house and buildings in proper repair; consequently the property soon shows signs of neglect and the system of occupying ownership gets a bad name.

It is stated that :-

"The farmers do not wish to buy their farms."

Of course they do not, as long as they can find landowners sufficiently "accommodating" to let their land at half its value and also do repairs that the farmers ought to do themselves. This is uneconomic and therefore unsound business. And it is generally admitted that low rents and low farming go together; men are tempted to take more land than they can manage, or more than they have capital for. It is conducive to extensive rather than intensive farming. It may be said that the remedy would be to raise the rents rather than to alter the system; but this is easier said than done, 
particularly having regard to public opinion in regard to rent.

There is also an ethical consideration: under the tenancy system the farmer is inclined to look to the landowner for assistance when in difficulties, instead of relying upon his own resources, and this is not good for his character; but it is a side which, it is right to point out, has become noticeable as a result of the agricultural depression.

It is argued that under the system of occupying ownership it is harder to maintain the standard of cultivation, and to keep the farmer up to the mark.

The answer to this is that in countries where ownership dominates the highest average standard is found, and the condition of the buildings is exemplary. This is not due entirely to ownership in itself but rather to public opinion which demands a high state of cultivation, and to the organization of co-operative societies and credit societies which have laid down rules and regulations that must be observed if the individual farmer wishes to enjoy the full benefits of membership. In practice the pressure a landowner can bring to bear upon his tenant's methods of farming is mil. If a tenant is farming badly the landowner can dismiss him for reasons of good husbandry and good estate management, but he must be farming very badly before the owner will resort to this extreme measure.

Finally, it seems to be practically impossible to establish any satisfactory system of credit for the farmers in this country; and the fact that the majority are tenants must have a great deal to do with it, for it is obriously much easier for an owner to borrow money than it is for a tenant. The need for this access to working capital has long been recognized by the Ministry 
of Agriculture and all leading agriculturists. Countless efforts have been made to start a system under which the farmer, particularly the small farmer, could raise shortperiod loans, but all efforts have failed. The pros and cons for tenancy and occupying ownership are here set out in juxtaposition.

\section{TENANCY.}

(I) The tenant lacks security, and therefore lacks permanent inducement to improve his cultivation.

(2) The working capital per acre is in practice less than it is under the system of occupying ownership on the Continent.

(3) The tenant often has a larger area than he can manage or capitalize efficiently.

(4) The two above causes have an adverse effect on the yield from the land.

(5) It is harder for a tenant to borrow than it is for an owner.

(6) There is a tendency for the tenant to rely too much upon the landowner.
OCCUPYING OWNERSHIP.

(I) Provides the best form of security.

(2) The occupying owner is not so much inclined to have more land than he can manage effectively.

(3) There is the incentive of ownership which leads a man to get the utmost out of the soil.

(4) A full system of credit societies is only possible under the ownership system.

(5) It develops self-reliance.

(6) It is sound, from the national point of view, for the land to be in the hands of many rather than concentrated in the hands of a few owners. 
In regard to the third question, "Are changes in our system of tenure necessary ?"

The answer is clearly yes; in fact modifications are already taking place that have been brought about rather by force of circunistances than by the adoption of any definite policy. And herein lies a danger; when changes come merely from force of circumstances there is drift and want of organization, which can only be avoided if the trend of circumstances be recognized and utilized to the public benefit. As already stated, one result of the Napoleonic wars was to increase the number of tenants-while the economic conditions created by the Great War, and recent legislation, are again causing a large increase in the number of smaller owners.

The great estate is bound to disappear-it is disappearing rapidly. The farmer is being forced to buy-we should see that he buys under sound conditions.

We have scen that the permanent mortgage is a menace to the industry-yet most of the new owners have heavy mortgages on their farms, becausc even yet there are no land banks. Under a proper system of loans, with sinking fund, every year's instalment paid by the farmer increases his margin of safety. Owing to the evil mortgage system many of the new owners will find themselves on the verge of ruin when prices fall, in fact cases of financial ruin have already occurred.

Although the great estates may disappear, landowners will still continue to have farms to let; but instead of letting them on ycarly leases we may well see a development of long leases.

We shall probably see a development of industrial farming on a large scale by companies.

We may see a development of co-operative farming, 
which would be all to the good, if a workable system that would appeal to our agriculturists can be devised.

We should see the landowner farming himself a much larger area of land than at present, preferably under some system of partnership with a highly qualified expert. This would be a new form of tenure in this country which will be discussed in greater detail later on.

The new Agriculture Act brings in modifications in the present system of tenure, rather than any new form of tenure. And the need is not so much of a new form as of getting back to the old form-occupying ownership, but under new and improved conditions. 
CHAPTER III

\section{AGRICULTURAL DRAMATIS PERSONA}

\section{THE LANDOWNER}

$\mathrm{O}$ NE cannot think about the landowner without the question of rent arising, ${ }^{1}$ and unfortunately most of the popular ideas about agricultural rent are fallacious. The general view of townsmen, who have not studied the question, is that the landowner is an extortioner and draws a large revenue from the land which he possesses; and they often question his right to possess it.

In the first place, with few exceptions, the landowner (or a predecessor) has bought his land just as he would have bought any other form of property - the one difference being that in buying it he contracts either consciously or unconsciously special responsibilities, particularly towards the nation and to the people living on his land; and an impartial study of the rents charged by owners of agricultural land for the last eight hundred years will show that these have not been extortionate.

In the fourteenth century rent averaged about $6 \mathrm{~d}$. per acre and good meadow land about $2 /-$ per acre (6d. in those days was about the equivalent of $6 /-$ in, say, 1914 ). 'To buy, land was worth about 12 years' purchase (i.e. the rent $/ 12)$. This rate of rental remained the same 
until I540, but the value of the land gradually rose to 20 years' purchase.

During the succeeding 160 years, rent rose by degrees to $5 /$ - per acre for arable land and $8 /-$ for grass land.

By I 770 the average rental of a mixed farm (grass and arable) was Io/- per acre, with 30 years' purchase as its selling value.

Taking the rental of a specific estate of 20,000 acres at four different dates, we find :

\begin{tabular}{|c|c|c|c|c|c|}
\hline In I799 & • & . & - & I9/- & per \\
\hline, I 8 I 2 & . & $\cdot$ & • & $25 / 8$ & ", \\
\hline , I 830 & - & - & • & $25 / I$ & ", \\
\hline, I $85^{\circ}$ & - & • & - & $3^{6 / 8}$ & " \\
\hline
\end{tabular}

If it be granted that the moderate increase of $6 / 8$ per acre between I799 and I8I2 was due to the landowner's desire to reap some benefit (and why should he not ?) from the high prices of produce then prevailing, the increase of I I $/ 7$ as between I 830 and $185^{\circ}$ was clearly not due to this reason, but simply to the fact that owners were spending vast amounts of capital in developing their farms. In the case of Coke of Norfolk, when he succeeded to his property the rent roll was $f_{2}, 000$ a year. He spent $£ 500,000$ in making his property productive, in turning semi-waste land into fertile land producing food for the nation. And the result-a gross rental of $£ 20,000$ a year-could not be regarded as extortionate. And financially he was one of the most successful of owners.

In the second place, coming to recent times, the owner does not draw large revenues from the ownership of land-in 1914 the total income received in the form of rental by all persons owning land and houses in the United Kingdom was about $£ 285,000,000$; but mark- 
only $£ 50,000,000$ of this vast sum represented the rental derived from agricultural land. And as at least 50 per cent in practice has to be returned for upkeep and development of the farms and estates, the landowners collectively only receive a net rental of about $£ 25,000,000$ -a sum of comparatively small importance when the present national expenditure is envisaged.

But even this $\{25,000,000$ does not represent the rental of the land itself; for the amount spent by landowners in equipping and developing their land, before it could be utilized by the tenant farmers, was so large that this $£ 25,000,000$ represents only about a 2 per cent rate of interest on the capital thus expended.

The landowner receives as available income either a low rate of interest on capital expended in developing the land, and no rental for the land itself, or a moderate rental for the land and no interest on his capital expenditure ; it is one, or the other, not both.

When the great depression came (in 1870 ) the landowner bore the brunt of the loss it entailed; for, although many farmers went bankrupt during this period, landowners suffered a permanent loss of rent and capital. To-day the landowner is hit harder by the conditions brought about by the Great War than any other section of the agricultural community. Examination of the account books of typical estates shows that after paying taxes, rates, and the cost of upkeep of farm-houses and buildings, the landowner is left with only $3 / 9$ in the $\oint_{\text {as }}$ effective income; often much less. This is a fact that should be realized by the townsman. In consequence, on all sides our fine country houses are being closed.

Rents in the United Kingdom are lower than in any of the developed European countries; they are too low 
for the real good of the industry itself. "Low rents, low farming " is almost a proverb, and a great Scotch farmer once said that high rental was the best of all artificial nanures. So much for the idea that the landowners are battening on the life blood of the agricultural industry.

I am not defending landowners because I am myself a large landowner-but because, as such, I am in possession of facts which those who attack agricultural owners obviously do not know, or that in a blindly partial spirit they deliberately choose to ignore. Landowners have ever proved themselves patriotic and have done the best according to their lights; and I have no hesitation in affirming that there is no ground for accusation against the agricultural owner on the score of rack-renting. But I wish I could say as much in regard to their past attitude and action in regard to the enclosure of common fields. ${ }^{1}$

\section{ENCLOSURE OF COMMON LANDS}

There can be no doubt that this policy, which was adopted and rigorously pursued for several centuries, led to the extinction of much that was valuable in our

1 The Clarendon Press, Oxford. Lord Ernle on the Story of Enclosure says, in the Times Literary Supplement, February I th, I92I, reviewing MIr. W. H. R. Curtler's The Enclosure and Redistribution of our Land:-

"The return of the Enclosure Commissioners, I 876, shows that the land enclosed between I 845 and I 875 amounted to 590,000 acres, which was divided among no less than 25,930 people, in the following manner: 620 Lords of the Manor received on an average $44 \frac{1}{2}$ acres each; 21,810 common right owners received on an average 24 acres each ; 3500 purchasers (of land sold to pay expenses of enclosure) received on an average Io acres each. It is not disputed that claims were often incapable of legal proof, or that the value of a common right may often have been underestimated 
old English country life. It killed the community spirit, which we are now striving to revive, and worst of all it turned the tillers of the soil into a landless proletariat.

The landowners have just this excuse-at that time everyone was adrocating enclosure as the great means of securing the development of agriculture and increased yield from the soil; I am not aware of anyone who raised his voice against it, or at any rate of anyone who put forward a constructive counter-proposal-as was the case in Prussia for example. The whole nation seems to have stood for enclosure; and most enclosures were sanctioned and confirmed by Acts of Parliament. In view of this fact the accusation against the landowners of wholesale robbery cannot be justified. In support of this statement an examination of enclosure legislation shows that land was, in fact, allotted to the majority of the commoners; but as they could not afford to fence it, as requircd by law, they had to sell to the surrounding landowners.

\section{OWNER AND LABOURER}

Another mistake which owners have made, and I fear still are making, lies in their having failed to identify themselves sufficiently with the agricultural labourer and his interests. For many generations the country labourers were oppressed and exploited-there is nothing to be gained by mincing words; they were housed badly,

by the Commissimers who were responsible for the awards, or that the allotted portions were often sold as soon as they were made. But any accusations based on these or similar facts inust fall very far short of a charge of robliery. It is a proof of Mr. Curtler's judicial spirit that be emphasizes the real blot on enclosures, and lays to the charge of the movement the sin of ignoring the moral claims of the poor." 
paid badly, they lived under distressingly bad conditions, and with little opportunity or prospect of advancement. And I cannot but feel that the Church and the landowners could have been more active in advocating and effecting improvement.

Coming to quite recent times, if owners as a body had been more sympathetic with the quite reasonable wish of agricultural labourers to form Trade Unions of their own, the feeling between labour and the other two sections of the agricultural community would have been far better to-day.

Or again, when the National Insurance Act came into force, had landowncrs united in assisting the working men to retain (and work under the Act) their Friendly Societies, formerly so numerous, these could have been saved from extinction.

Where they have been saved they have justified their continued existence to the full.

Even in these days, with labour becoming more and more powerful, I still believe that the landowner can play a great part where he is qualified; he will still be accepted as leader-simply because he is outside faction, and his integrity is known.

The landowner's chief claim to consideration lies in the fact that he is the largest shareholder in the agricultural industry.

It was his capital that rendered possible the great developments of the nineteenth century; and it was his sense of duty, and his interest in these developments, rather than motives of gain which led him so to invest his capital. He was, in fact, a patriotic investor and alas too often a philanthropic investor as well.

But the present situation demands more landowners; no longer must landowners be mere philanthropic investors 
of capital. Estates in the future will have to be run on strictly business lines. And the owners must become more and more interested in the actual production of food, and so become effective leaders in the organization and development of the industry. Years ago the Danish landowners realized these two points, and to-day their position is unassailable.

\section{THE LANDOWNER FARMER}

Force of circuinstances will compel owners to charge such tenants as remain to them rents that will more and more approach the economic rent of the land. If I am correct in my forecast of an upward tendency in rent (and I believe this will be the case whether land remains under private ownership or passes to the State) then one result will be to squeeze out the indifferent farmer and the medium-sized farm, say, of 300 or 400 acres. These will be replaced by capitalists and syndicates, and by the owners themselves farming much more than they do at present. And this will be all to the good if the Government sees that the right proportion of smallholders is maintained-national stability demands this, as also does justice to the legitimate desire on the part of labourers to have access to the land.

But if the landowner is to farm more land than in the past, he will have to regard landowning as a profession and train for it. Even then it will not follow that landowners as a class will make successful farmers ; as a rule they have too many other duties and distractions-and farming is a great occupation, and an exacting one.

There can be no doubt that every owner should have a thorough understanding of "land economics," and so 
be qualified to take an active part in agricultural development. But it is only those who have been thoroughly trained, and who mean to make farming their main occupation in life, who should attempt it on any large scale.

For those who are engrossed in public business or other occupations, there is still a way in which they can take a practical interest in farming-and farm their own land, and that is by adopting the partnership system. This has been largely developed in the United States and other countries; it has rarely been resorted to here, and yet the advantage to the landowner is great.

\section{MORTGAGE}

Stress has been laid on the evils of the mortgage, and landowners have suffered and still suffer from the mortgages that weigh down so many estates. Long ago they should have taken steps to free their land from mortgage ; at this moment money is too scarce and dear to do anything in the matter.

But we can see how it might have been done if we study the Landschaft system of credit in Germany. Briefly, landowners grouped together and pooled their land for the purpose of providing collective security; any member of the local group or society could borrow money for the purpose of devc'oping his estate. Bonds were issued which were negotiable in the open market, and were eagerly sought after. A sinking fund was provided which extinguished the loan in 40 years.

The system has worked admirably for over 100 years. In 1914 over $£ 150,000,000$ worth of these bonds were current. 


\section{TIE CENTRAL LA.DOWNLIS' ASSOCIATION}

Landowners themselves stand in need of combination just as much as any other section of agriculturists ; they must unite if they are to lead the industry and safeguard its interests. In rgot the writer, in association with several other landowners who were feeling the need for such combination, took measures to secure the creation of the Central Landowners' Association. Under the intelligent leadership of the late Lord Onslow as chairman, and Charles Bathurst, now Lord Bledisloe, the Association soon became a power in politics-but it remained small in numbers until about two years ago when it began to expand rapidly.

In 1909 the Land Union was formed and they have quite distinct spheres. The Land Union stands primarily for urban landowners, the Central Landowners' Association for agricultural owners. The Land Union is essentially a fighting body ; it defends its members, attacks existing abuses as they affect landowners-it is really a Property Defence Society. 'The Central Landowners' Association has other aims; being a body with wide experience of land problems it seeks rather to take preventive measures, and to guide legislation affecting land on right lines. It recognizes that the landowner should not put up a fight merely for his own sectional interests; that his claim for the consideration of his fellow-citizens lies in the fact that he takes a broad and national view, and that his object is the development of the agricultural industry as at whole.

\section{THE FARMER}

The English farmer is, and for a good many generations has been, an individualist of the most pronounced kind. 
In the main, as would be expected, he is conservative in politics, while the men he employs are largely liberal. The farmer and the labourer to a very large extent have voted on opposite sides at elections. This cleavage is more marked in England than in other countries. Chiefly, I think, because of the reason already giventhe agricultural labourers have so little direct interest in the land.

This division in the ranks of the industry is bad both politically and economically.

Along with his individualism and conservatism the British farmer possesses dogged determination to a remarkable degree. He has suffered more than any other race of farmers from the neglect and stupidity of Goverument, and from the apathy and sometimes even hostility of our land-ignorant townsmen. He has seen the whole nation absolutely indifferent to the prosperity or ruin of agriculture-the primary national industry. In spite of it all he has held on.

If he has not progressed as much as farmers in other countries since 1875 , who is to blame? Prices were against him, railway rates were against him; and that organized agricultural instruction, which revolutionized agriculture in other countries, was denied to him. For years during the great depression the farmer could only just exist ; how could a man in such a position, alone and unaided, improve the standard of his farming ?

Yet it was during this very period of depression, when our agriculture was on the down grade, that the most remarkable expansion of that industry took place in continental countries-both free trade and protected.

The reasons for this great difference in results are these :--

First, when the depression came upon us, we were 
leading the world agriculturally; we were content with our position and I think most farmers felt, even if they did not proclaim it, that English agriculture could not be improved upon-a resting upon one's oars attitude that is always dangerous. And so they did not realize that it was necessary to organize in order to meet the new competition successfully.

Secondly, even before $1 S_{75}$, other nations had begun to organize their agricultural industry, and we had not. They began to develop systems of agricultural cducation that proved to be (as they ever must) the foundation of sound and rapid development; whereas it was not until Igro that we began to concentrate attention upon developing a system of agricultural elucation. ${ }^{1}$

One of the strongest indictments that can be brought against our agriculturists is that, as a whole, they have been opposed to education and opposed to co-operation which is the bedrock of organization.

We have, and for long have had, certain outstanding farmers in each county, who are sccond to none in the world in skill and general intelligence; but the difference between our good farmers and our bad farmers is greater than exists in any other country, and it is the bad farmer who pulls the average down.

And the reason for a more uniform standard amongst the agriculturists of other countries is, precisely, the superior education and organization which have tuned up the whole industry.

It is best to face the situation frankly, and to admit that in the United Kingdom there are a large number of farmers who, from want of capital and knowledge, are not obtaining from the land the production it should

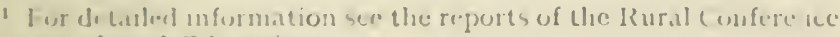
o. Agricultural Education. 
yield. As stated clsewhere (vide page 104) the yield of the land of the United Kingdom has not been increasing, even with increasing prices for agricultural produce; for instance, in the period between 1904 and 1914, the production from our land was declining.

This is the fundamental fact.

The nation as a whole has become aware of this fact, and they blame the farmer, or the landowner, or both ; they in no way realize that the unsatisfactory condition to-day is mainly due to the lack of a national land policy, and now they demand that "something" should be done.

This is the reason why the Government is now concerning itself with the land and agriculture in a way it has never done before. It is unthinkable that the Government would have interfered at all had the yield from our land been increasing, as is the case in Germany or Denmark. Any interference on the part of Government means a greater or less degree of official control. And there is nothing more distasteful to the British farmer than official control. It is useless for him to battle against control ; there must be control of some kind if we are to organize and develop the industry.

But official control which is dangerous and unsound can be checkmated, if all agriculturists will combine and show that they themselves can control their industry, and develop it in the nation's interest as well as in their own. This is the only sound control.

In 1866 the Central Chamber of Agriculture was created; its object was to bring owners, farmers and labourers into one organization, but it never attracted labour, and although it has done much useful work for the Agricultural cause its membership never exceeded about twenty-five thousand. It was in no way a Union. 
In $190+$ the Farmers' Union was started by Mr. Colin Campbell and a few others; it grew steadily up to I9I 4 , and from that date, owing to conditions created by the war, its growth has been rapid ; to-day it has a membership of over one hundred thousand, or to put it in another way one farmer out of every five of all the farmers in England belongs to it. This is good, but it is not good enough ; every farmer should belong to this Union. If the farmers will work harmoniously with the Landowners' Union (The Central Landowners' Association) on the one hand and with the Labourers' Unions on the other, and if, above all, they desire and pursue a sound and sane policy, then will their power be great in the land-and enduring. But if they narrow down their interests to those of a section and do not work for the development of the whole industry, ever bearing in mind the national point of view-then short will be their day!

Let those farmers, who think that the owner ouglit to be abolished, remember that there is a growing feeling amongst labourers that the farmer should be abolished; but there should be no question of abolishing any section of the agricultural community. Again let me say to those others who wish to retain the landowner, because they like to use his land at a rental that is below the economic rent, that no measures can be devised which will stop an owner from selling out when the force of economic circumstances compcls him. That is a law of economy which it is futile to fight against ; rather, as has been said already, farmers should seize upon the first favourable opportunity to urge the creation of land banks, so as to enable the occupier to buy his farm when need arises.

Another very important point for the farmer to bear 
in mind is that, at the present stage, it is much better for farmers to combine for industrial purposes than for political; combine industrially, and political power (and I am all in favour of seeing a certain number of farmer M.P.s) will come as a consequence. But to combine politically in the first instance is to pursue a shadow and miss the substance.

The new machinery set up by the Government (the County Agricultural Committees, etc.) concerns itself directly with the industry and is not, or should not be, political. Therefore agriculturists should make every effort to capture this administrative machinery, and reduce the official element to the minimum. The farmer of the future will, I am sure, have to give more of his time to public or semi-public work than he did in the past. The Miller of the Dee attitude, "I care for nobody and nobody cares for me," is no longer possible. The large farmer will have to think more about the interests of his smaller brethren than he has done heretofore. And if collective buying and selling, and access to credit for short-period loans, are vital to the small farmer, then the large farmer will have to throw himself heart and soul into the movement. And in these days of combines, when it is impossible to say that a ring in this or that important commodity will not be made, the large farmer will in the long run find this to be to his own advantage.

Another point is that many of our smaller farmers are not good business men; buying and selling has been reduced to a fine art by the dealer, and the properly run co-operative society can undertake all that side for the man who may be a good cultivator but not a good business man. By a properly run society is meant one which is run on sound business lines, and has a well- 
trained business man at its head. Unfortunately this is not by any means always the case in this country, and this leads to unsatisfactory results, and brings odium on the great principle of co-operation in agricultural circles.

Again, as a class, our farmers have not recognized as they should the advantages of education, both technical and general. How often has a farmer said to me, "Look at Mr. S., he never had any education and he is the most successful man I know." Two points are overlooked in this somewhat crude statement, one-that Mr. S. is educated, he has educated himself, and the other that, as a rule, it will be found that Mr. S. himself values education highly and is deternined to give his children the best education that can be procured. Every successful farmer must have a high degree of technical knowledge and theoretical as well, although often he may be hardly conscious of his theoretic knowledge. He must be able to handle and organize labour well. He must have business acumen, for buying and selling to best advantage are important factors in successful farming. More than in almost any other profession he must be able to think ahead and plan his course, not for one year but for a series of years. Is it not clear that the trained brain will do all this more effectively than the untrained ?

It augurs well for the future that the National Farmers' Union have a strong education committee, which takes a broad and progressive view of the needs of the community. Nothing can be of greater importance than to lead farmers to take an active interest in the educational developments within their respective counties. For it is only by making use of all the information and guidance which the farm institutes and county education 
staffs can give, that we can hope to improve our standard of farming. Our average farmer does not yet understand the economic use of artificial manure or even of the fundamental farm-yard manure; he does not understand the economic feeding of live stock; he has not made a study of the proper organization of farm labour. Yet these points are of the greatest importance in the economy of the industry. There are still too many farmers who do not understand that science has been of untold value to them ; were it not for science such every day substances as superphosphate, basic, sulphate of ammonia, would not be there to help the farmer in his conquest of the soil. If farmers fail to see what research has done for them in the past, in spite of this constantly recurring evidence, how make them understand the still unlimited resources which science can make available for agriculturists ?

Finally, the organized farmers should have a strong publicity department and be prepared, when need arises, to carry on an educational campaign amongst our ignorant townspeople and to answer maliciously false attacks on the industry.

During the war our urban consumers made frequent allegations of profiteering against the producers of food; in their ignorance they accused the farmer of profiteering and running up the cost of living, when the enhanced cost was really due to world prices. As a matter of fact, owing to Government action in regard to wheat and other commodities, our farmers actually received considerably less than the world prices. No one denies that a large number of farmers did well during the period of the war, but it is quite certain that they did not recoup themselves for their losses during the long period of depression when the nation lived on the landowners' 
and farmers' capital! The farmers were actually helping to pay the bread subsidy during the years when the world-price for wheat was higher than the controlled price for English wheat. 'The total loss to our farmers under this head is some $f_{15} 5,000,000$.

Another injustice occurred when the consumer blamed the farmer as he often did for increased cost, when this was really duc to the high commission demanded by the middleman or distributor of the commodity in question. In the summer of 1920 , when consumers in most of the large towns had to pay $2 \mathrm{~s} . \mathrm{Sd}$. a gallon for milk, the dairy farmer was getting only rs. 3 d. a gallon; and this, owing to increased cost of production, left only a small margin of profit. On the other hand, the distributors were charging is. $5 \mathrm{~d}$. a gallon for merely handling the milk, an altogether exorbitant charge!

The consumers so vastly outnumber the producers that it is dangerous to leave them in ignorance of these facts; especially as with certain politicians their one aim in life seems to be to spread lying statements about the land and the agricultural industry. I suppose it is the only sort of "political effort " of which these mediocrities are capable! All agricultural bodies should subscribe to form a strong bureau for publicity work; it is urgently needed.

If the farmer is to keep his end up he must combine, and more than ever during the coming years must the farmer's watchword be "Organize."

For the lis tory of the Central Chamber of Agriculture sec the buk by Sir Herbert Bathew. 


\section{THE LABOURER}

The agricultural labourers outnumber the farmers by about two to one. This proportion would be much greater if it were not for the large number of smallholders (cultivators holding under 50 acres), who are classed as farmers. Also it should be remembered that the proportion of labourers to employers has varied as the proportion of pasture to arable has varied; grassland employs little labour and this, from the national point of view, is one of the strongest arguments for reducing the area of grass and increasing the area of arable.

It is a matter for great regret that the interests of the labourer and of the farmer are held to be divergent, to an extent unparalleled in any other country. This divergence in interest is due to several causes, chief among which are :-

(I) The fact that the agricultural industry is not in a highly organized condition and therefore does not tend to unite all those engaged in it.

(2) That the labourer, for many generations, has been a paid " hand" with no direct interest in the land he tills.

(3) A feeling of grievance at the way in which enclosure was effected still survives.

(4) The way in which the poor laws were administered between 1810 and 1836 .

(5) The deliberate policy of a certain type of politician in setting one class against another since 1884 .

(6) The attitude of many farmers to their men, treating them as beings of a lower order.

It is a commonplace that the labourer votes in opposition to the farmer, and this attitude is a great barrier 
to the success of any agriculturist standing for Parliament. Yet, if the organized industry is to carry the weight it should politically, it is essential that agriculturists should vote "solid." The labourer is not to be blamed for this attitude; it is the result of low wages and bad conditions in the past, and to an ingrained feeling of suspicion due to the treatment that has been meted out to him for so long.

Coming to the immediate present-a revolution in the labour situation has taken place within the last five years; a minimum rate of wages is enforced by a Statutory Wage Board, our agricultural labourers are rapidly enrolling in Unions and a spirit of independence has appeared. This revolution has perturbed and is perturbing our farmers, especially the smaller farmers who employ only two or three labourers; and yet all things considered the upheaval has not been so great as might have been expected.

Nothing but disaster can follow if the organized farmers on the one hand, and the organized labourers on the other, stand out simply for their own sectional interests, and forget that these can be secured only by thinking of the good of the industry as a whole. (I am here referring to the Unions not to other organizations.) So that the immediate problem is how to get labour to work shoulder to shoulder with the farmer in the development of the industry. This implies the need for good feeling, which is essential as it is the only foundation on which to build.

Although in politics the labourer and the farmer are opposed so generally, and there are farmers whose treatment of their men leaves much to be desired, yet, on the other hand, there are many farmers whose relations with their men are excellent. And where 
such relations are good, they are about ideal ; the man, interested in the land, keen on the prosperity of the farm, with a nice cottage and garden and a pig, and the farmer on his side regarding the labourer as an old friend and careful of his interests. How different from the relations between the factory hand and his employer!

Granted then this good feeling as the basis, the solution of the problem will be found in regaining what was lost by the wholesale enclosure of the commons, i.e. the labourer's direct interest in the land. He must have easy access to land for allotments and later on to land for small holdings - that is the first point. The second is to give him a certain share in the control of the industry, chiefly by means of Councils analogous to the Whitley Councils and operative in a fairly circumscribed area; and a share in profits over and above his fixed wage. Further, it must be made clear that an adequate wage for labour is indeed regarded as a first charge upon the industry. Many employers were aghast at the idea of paying a wage of $45 /-$ a week to their men; and yet there is little doubt that, from the end of 1917 to $1921,45 /$ - per week was not as good a wage as $20 /-$ per week before the war. Thirdly, the labourer has votes at parliamentary and county council elections, and he should sit upon local bodies as well as in Parliament-this is a development which is undoubtedly coming. And, fourthly, we must make good our promises to improve housing conditions; young men wanting to marry, and remain in the country, must be able to get a decent cottage at a fair rental.

The energetic action which the Government have been taking since I9I7, to maintain and increase the acreage under the plough, should be a guarantee to the 
labouring man that at last the Government do realize that it is ploughland that employs the largest amount of labour. 'This is a very important point and it is clearly understood by the labourers themselves; and there is no doubt that they resent the laying down of land to grass, for they know that it is taking away their occupation.

But the point that labour does not yet fully understand is - that no possible legislation on the part of any Government can prevent the farmer laying down land to grass, if his only alternative is to retain it under the plough at a financial loss, or with an wholly inadequate return upon his outlay.

A Government can take measures to tune up the indifferent farmer, and in this it should have the wholehearted support of labour; it can further secure the good farmer against loss in growing crops on arable land, which it is to the nation's interest to have grown; and by insuring the farmer against loss the Government gails a right to see that the farmer pays his labourer an adequate wage. All that is a workable equation; and no one should understand more clearly than the labourer the basic principle that the farmer cannot go on producing food, cuitivating the land, and so employing labour, at a loss.

And that is the reason why the labourer should support the farmer's demand for a fair price for his produce.

But nothing that a Government can do will enable the farmer to farm against bad labour, or an inadequate output per man. That is the bed-rock of the problem; whether a fair proportion of the land is to be under the plough, or whether there is to be a wholesale laying down to grass, rests largely with the labourers themselves to say. There is so much 
wrong-thinking on this subject-labourers think they have to work for farmer " Smith," and if they slack that they are scoring off Smith, but it is not so ; it is the land itself that demands a certain minimum amount of labour from each and every cultivator, and the man who slacks is cheating the land, and the land will punish liin.

For if the output of work per man sinks below a certain level, Agriculture, the "Land Industry," will suffer and decay, and the workers in the industry will feel despair in their hearts, for there is no feeder to despair like a decaying industry ; with the final result-more land will go down to grass and thousands of men will be driven from the countryside. A grave responsibility rests with the leaders of labour and with the officials of the Trades Unions, for it is they who more than anyone else can enable the labouring men to take a clear view of the situation. And our intelligent and progressive owners and farmers should at all times be ready to confer frankly with these leaders on subjects affecting the welfare and development of agriculture.

There has been talk of the $4 \delta$-hour week being applied to agriculture, but how absurd to try to treat agriculture as if it were exactly like the industries carried on under cover and unaffected by the weather! In some weeks it is impossible to put in more than 30 hours on the land - the quarrel is not so much with the 8-hour day as with the 48 -hour week. I believe if a longer period were taken, for example a 208-hour month instead of the 48-hour week, the difficulty about bad weather would be largely overcome. Nothing should be done which would put the agricultural industry at a disadvantage as compared with urban industries-it cannot afford it. It is not suggested that the agricultural labourer should 
be at a disadvantage as compared with the town labourer in regard to leisure hours; but when it is a question of getting in the nation's food supply in a variable climate like ours, the necessary adjustments to meet the case should be made. In bad weather the hours of manual labour are perforce curtailed, and I have been astonished at the amount of serious reading the agricultural worker can put in during the year if he is so disposed.

The agricultural labourer in his own sphere is a skilled labourer, and he should be treated as such. It should be open to the energetic worker to earn much more than the minimum wage by means of piecework, wherever this can be arranged, and there could be much more piecework if the farmers gave their minds to developing it ; and the labourers should agree to the principle.

In the winter months the hours of work are short, work is often altogether held up by the weather, and the labouring man can have his hours of leisure-and in summer, too, except at times of pressure-hay and corn harvest, for example. At these times there should be no question of knocking off at 5 o'clock; work should go on late into the evening and the overtime should be well paid. 'The unfortunate thing is that at the present moment many labouring men stop work at 5 p.m., regardless of any other consideration, and the overtime wages do not tempt them. There is the other side; many of the farmers think they cannot afford to pay overtime and so do not encourage it. The nett result is serious; less work is being put into the cultivation of the land.

It is not that I am an advocate of long hours; in the factory the 8-hour day is certainly long enough - too long in some cases - and an 8 or 9-hour day in agriculture may be long enough, though personally 1 would rather work 9 hours on the land than 6 hours in a factory. 
The point is that, in view of the uncertainty of the weather, there must be elasticity; and the objective should be so to increase the number of men in the country on holdings of their own, that there will be a surplus of men who while they work part, or even most of their time, on their own holdings, would give a certain number of days to the surrounding farmers. These men would be the very finest type of workers and such a reserve of additional labour would be invaluable. While one wishes to see the best possible conditions for agricultural labourers, and increased opportunity for advancement, it is only fair to the industry to state that investigations show that, even now, the proportion of labourers who rise to an independent position (i.e. become farmers), is high as compared with other industries.

The working of the National Insurance Act is another matter closely affecting the rural workers. The old Friendly Societies were splendid institutions; often they were worked very well, and the village Friendly Society became the meeting-place of the serious-minded men in the village, and much good work was done voluntarily by men with a high sense of duty. These small Friendly Societies, wherever financially sound, could and should have been preserved.

Unfortunately the way in which the Act was worked has led to the extinction of most of these societies, and to the rural workers being insured in the great Urban Insurance Societies. The result is that the healthy countryman is paying for the ill-health of the towns man. This is not fair, and it could have been avoided; it has been avoided in two or three counties. In Yorkshire, Oxfordshire and Lincolnshire, and more largely in Scotland, the small Friendly Societies were kept from dissolving and formed into County Associations 
approved by the National Health Insurance authority. Time has proved the wisdom of this action, and these associations are now the soundest section, actuarily, under the National Insurance Scheme. Every county should have had its " Rural Workers' Insurance Society."

The matter was put before the Lord-Lieutenantsfor it was pre-cminently a question in which the landowner should have shown his sympathy with the real interests of the working man, but, save in a few cases, nothing was done; a great opportunity was lost owing to our usual failing - want of vision. It might even now be possible to do something in this direction, but it would be more difficult as the system is established.

The questions we have been touching upon are important, but they are insignificant when compared with the great problem of Education-the education of the children of the rural workers. The Fisher Act will have a far-reaching effect; it will take years to set it going in the country, but the final result will be that the country child will receive an education, of its own type, as good as is provided for the town child.

No longer will all education cease at the age of 13 ; it will be carried on by means of continuation instruction from 14 to 16 , and undoubtedly in the end till 18 , as it is in Denmark. And why should we be behind? 'This continuation instruction will cmbrace general education as well as technical, so that the effect upon the general intelligence of the future labourer will be very great. If the new system is developed on right lines the resultant good to the nation and to the individual will be incalculable.

But there are dingers to be avoided. In the past, instruction in the elementary school was too much based upon the textbook. The manual side was neglected. 
We must avoid the other extreme. Again, the ideal was formerly that of the "Educational Ladder," up which the exceptional pupil might climb to the top-the average pupil was neglected-and in many cases the supposedly exceptional pupil did not get to the top because he was not really exceptional. Now the ideal is that of a great "Educational Highway," along which all shall travel; well and good, provided that it be clearly recognized that human beings, though of equal value in the sight of God, are not equal in mental capacity any more than they are in size or weight. Some children can travel fast and some slowly, some will go far upon the highway and others not so far, and there can be no greater cruelty than to attempt to force the pace of the slow mover. The high road must pass via secondary education to the university and travel must be free from one end to the other. The majority of men have to work with their hands; let us, therefore, have the most intelligent race of workers that is possible, men who will realize their responsibility to the nation and to their neighbour as well as to themselves, men who will take an intelligent interest in their work. This means the maximum practicable amount of education for the workers' children.

In the country, education must inculcate a love and understanding of things that grow and a love of the countryside; it must be based upon, and draw its inspiration from, surrounding life; it must not be an attempted reproduction of urban education. In fact the reverse should be the aim; urban education should as far as possible reproduce the good features of rural education.

All this for the rising generation, but we must not leave out those who are past school age ; great work has been done by adult classes in our towns, and though 
inore difficult, still experience proves that they are of equal value to the rural worker and therefore should be developed. It is essential that he should be given an insight into the simple economics of the industry; there is nothing our workers stand in need of so badly as some understanding of economic principles. With that knowledge they can take a broader view, and they will be able to distinguish between what is good and what is bad for their industry; and as voters they will be better able to weigh the questions upon which they have to vote. ${ }^{1}$

\section{THE WAGE BOARDS}

It is impossible to bring this section to a close without a brief reference to the Wage Boards.

I was onc of the first to advocate their formation; I believed them to be essential, and I still hold to the principle.

During the war we could not have done without them ; independent action on the part of the labourers and farmers could never have succeeded in adjusting the wages throughout the country, as it was necessary that they should be adjusted. There can be little doubt that witheut the wage boards a very dangerous situation would have arisen between employer and employed. Further, the Government could not have given the guaranteed prices to the farmer without the set-oft of the Wage Boards.

During the period of great crisis I consider that the Central Wages Board made a great mistake in its policy - its one aim should have been to fix a generous wage, and not to go into details in regard to hours, or to interfere in the relations between employer and employed. 
The motto should have been " An adequate wage, but free individual bargaining in all else."

Local custom varies from farm to farm even in the same county, and it is not only the farmer who may prefer a particular method of dealing with " confined" labour, but the men themselves; and the method may be very different from the one laid down by the Wages Board. Again, the rate fixed for young unmarried men was undoubtedly too high, in comparison with the wage granted to the married man with a family. In short, the present Wage Boards undoubtedly suffer from a want of elasticity.

Many farmers hold the view that they would willingly do without the Government's guarantee of a minimum price for wheat if they could also be rid of the Wages Board; I cannot agree with this view. In the first place, the guarantee is a valuable recognition of the important principle, that the nation cannot ask the farmer to produce a certain crop without guaranteeing him against loss in its production. In the second place, I do not believe that public opinion would consent to the abolition of Wage Boards.

There is a more practical question: are the present constitution and procedure of the Wage Boards all that can be desired, or should alterations be made ?

I think that men who have had practical experience of the working of Wage Boards will agree that there is much room for improvement; the present system under which the employers sit on one side of the table and the workers on the other, and the appointed members upon a raised dais, leaves much to be desired. A real round-table conference, with the members sitting without reference to section, would be more conducive to discussion"; really, the need is for Whitley Councils to 


\section{AGRICULTURAI DRAMA'TIS PERSONA 69}

be applied to agriculture. In fact, the National Alliance of Employers and Employed are taking up this question and have already started Councils in one or two counties. I think that agriculturists would be well advised to back this movement; and if it makes good, and meets a need, this system might in the end supersede the present Wage Boards.

Rowntree's Ilow the Worker Lives, and Mr. F. E. Green's book, A IIistary of the English Agricultural Labourer, 1870-1920, published by ling and Son, should be read as giving the labour point of view: The latter, perhaps not unnaturally", gives a somewhat biased view. 


\section{CHAPTER IV}

\section{PRODUCTION}

IN THE UNITED KINGDOM AND CERTAIN FOREIGN COUNTRIES

THE two great functions of the land in the civilized state are to produce the economic

1 maximum of food for the nation, and to give employment to the largest number of cultivators.

This statement may be regarded as an axiom, and as the measure with which to gauge the development and degree of prosperity of the agricultural industry in any country. Unless the land is producing its utmost, it will not be giving employment to the maximum number of cultivators; and conversely, unless there are a sufficient number of trained cultivators of the soil, the land cannot be put to its fullest use. And where this is the case it means that the land, the great source of new or primary wealth, is not making its proper contribution to the wealth of the nation. Or to put it in another way, the nation's greatest asset-which is land-is not being made the most of.

The economic importance of primary wealth is not as fully realized as it should be in this country; brought down to its final issue, production from the land is paid 
for by (or given in exchange for) the wealth produced by urban industry. ${ }^{1}$

In regard to the production of food, other considerations than the purely economic come into play; for instance it may be necessary, from the point of view of defence, that a nation should grow the largest possible amount of wheat, more than might be strictly economic. Again, it is in the interest of the whole nation to maintain the area of land under the plough, on account of the employment it provides, although grass land may be the more advantageous from the farmer's point of view. Most important of all, the proportion of people living on and by the land must be maintained, otherwise the nation's health and standard of physique will suffer. 'This is a point of supreme importance to every townsman ; in their own interests they must sce to it that there is an overflowing agricultural population, so that a reasonable annual influx therefrom may maintain the physical standard of the towns.

Let us now apply our measure to the agricultural industry in Britain, and see whether the industry is in the right condition, or the land developed as it should be.

In 1914 the gross production from the land was

1 Keferring to the many millions of pounds sterling of primary wealth produced from the soil of the United States onc of their fovernment reports say's :-

"The sum is one that challenges the American imagination; these virtually nine billion dollars $(£ 1,752,000,000)$ penetrate into every form of commerce, art, industry, socicty. It is their fructifying magic that swells bank balances, hat makes possible daring explnits in the realms of developinent and general expansion" (L.S.A. Department of Agriculture, 100,9$)$.

In America there is a very clear understanding of the importance of primary wealth, and if our Government liad understood this more fully the land of our limpire would be vastly more productue than it is to-day. 
practically the same as it was in $18 \mathrm{I}_{4}$, and much less than it was in 1840 . The low prices and consequent agricultural depression of the eighties and nineties caused this falling off in production; but although from the year 1904 to rort prices were improving, production was stationary-or if anything tending downwards. Nationally, nothing could be more serious. We will deal later with the causes which brought about this state of aftairs.

Turning to the number of men employed upon the land, a serious decrease is found to have taken place during the last sixty years. In fact, it is only in the United Kingdom that the decline in the agricultural population has been absolute and not relative. In all other countries, although the proportion of town dwellers has increased more rapidly than the agricultural population, nevertheless the agricultural population has increased as well. So that the land of the United Kingdom is not to-day producing as much as it should, nor is it employing its full quota of labour.

It has just been pointed out that between the years rgo4 and 19I4, although the prices of agricultural produce were rising, there was little corresponding increase in production but rather the reverse. From the purely economic point of view this may seem hard to explain; for if the demand, as indicated by the enhanced prices, increases, so ought the supply, and it does so in most industries. But in the case of the farmer other factors come into play. The urban producer can switch from one class of production on to another, to meet the varying demand, much more rapidly than can the farmer.

The farmer has to think in rotations, i.e. in periods of three or four years. The prices may be good this 
year, but what will they be next year or the year after? In fairness to the farmer, the long period of agricultural depression must be borne in mind, during which period thousands of farmers went bankrupt and the capital of the industry was lowered by some $f_{1}, 000,000,000$. The urban critic must never lose sight of this fact. The farmer had to play for safety-his own personal safetynot the nation's. Who can blame him?

Hard experience had taught him that a land-ignorant nation cared little whether its primary industry flourished or decayed : the cult of the day was cheap food. Cheap food and cheap human beings, have we got rid of this pernicious doctrine? The war gave it a nasty knock; but can we honestly say to the farmer it is dead, never to rise again?

That the land of the United Kingdom was not producing what it should, during the greatest crisis with which this nation has ever been faced, was not the fault of the British farmer. It was the fault of a long line of Governments which systematically neglected our land resources. But it is easy to blame Governments; in the last resort the fault lies with the town voters, who hold the controlling power, and who in their blindness could not understand the importance to the nation of a flourishing agriculture and a highly developed land.

I'hen the war came and forced the Government and the nation to turn their attention to that neglected source of food supply - the land of the United Kingdom.

The Government set up committees to enquire into our home-grown food supply and its potential expansion. The findings of all were the same-that our land could and should produce more than it did. They reported that a great increase in cereal production was essential, 
and that the farmer should be guaranteed against any loss he might incur in meeting the nation's need.

For the first time in our history it was officially recognized that the agricultural producer could not be expected to produce needed food at a loss; and as a corollary, that if, in the interests of national defence, it was necessary to secure the production of certain crops at home, special arrangements would have to be made with the farmer. Otherwise, on business principles, he would produce the crops which paid him best, without regard to the national point of view.

This in no way implies want of patriotism on the part of the farmer. During the war the farming class was as patriotic as any other, and certainly never profiteered in the way that other sections of the community did. In fact the farmer had little chance of doing so; for there is no doubt that Government control affected him more adversely than it did most producers. And more than once it debarred him from receiving the current world price for his commodities. Yet over and over again the profiteering of the distributor has been charged against the producer-another result of the ignorance of the urban consumer!

Under the Asquithian regime it was quite impossible to induce the Government to consider seriously the augmentation of home supplies, even though it was abundantly clear that our dependence on sea-borne food was an ever-increasing danger; so that all credit should be given to the Coalition, under Mr. Lloyd George, for being the first English Government which has given time and serious consideration to the question of how best to increase the production of our land. Although the war is over, and the danger of being starved out by the enemy is removed for the present, increased production 
is none the less essential if we are to recuperate rapidly from the effects of the war.

How different the attitude and action of other European Governments and peoples! In every continental country the Government and all classes of the population were determined to see that the land produced its maximum. This is the first general comparison. We will nuw pass on to the consideration of production in Germany, Belgium, Denmark and France.

GERMIAY

Left to shift for itself, our agricultural industry was showing little sign of expansion during the decades preceding the war, as will be seen from our production figures for the 25-year period between $18 S S$ and 1913 .

And comparison with the German production figures for the same period enphasizes the unsatisfactoriness of our results. 'To illustrate this point, I am using an excellent set of diagrams prepared by Mr. Richardson, the agricultural adviser to the Government of the State of Victoria (Australia).

In considering the results achieved, we must remember that unlike ourselves the Germans concentrated upon securing a flourishing agriculture. All that science and education and organization could do for the development of the land was done. And Germany's protective tariff had the effect of giving the German farmer confidence that he would get a fair return for his efforts.

\section{DIAGRAM I}

This shows that between 1888 and 1913 our production of cereals actually decreased to a small extent ; potatoes 
alone of the main arable crops show a certain increase. In Germany the increase in cereals and potatoes during that period stands at just over oo per cent.

It should be noted that in I 888 there was already a great falling-off in our cereal production, especially in wheat, as compared with our high water period from I 840 to 1875 .

\section{DIAGRAM II}

This shows that although during the period under consideration there was a great increase in the area of land under grass, the corresponding increase in live stock was very small; whereas in Germany with no increase in grass a heavy increase was achieved, except in the case of sheep.

We must push our comparison further if we are to arrive at a true understanding of the difference between the production of the land in the United Kingdom and in Germany.

The area under cultivation in the former may be put at 50,000,000 acres, in the latter at $80,000,000$ acres. ${ }^{1}$

Our population in I9I 3 was about $45,000,000$; theirs $68,000,000$.

In that year our total home production of cereals amounted to $308,000,000$ bushels. Theirs amounted to nearly $I, 500,000,000$ bushels, or roughly five times as much as our production.

In I9I3 Germany produced I,988,000,000 bushels of potatoes, while we could show only a total of $283,000,000$

1 "Land under cultivation" means all land, whether arable or grass put to agricultural use; our exact figures are $47,000,000$ acres, plus 9,000,000 acres of rough hill grass land which I value at 3 acres as equivalent to 1 acre average grass and so reduce it to $3,000,000$ acres for the sake of round figures. 


\section{GREAT BRITAIN.}

1883.

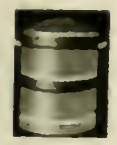

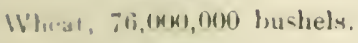

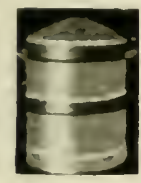

Oats, 151, Orn), (h00 bushels.

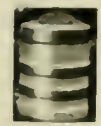

Increase, 1? pres cent.

Decrease, 6 per cent.

1913.

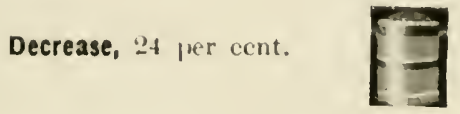

-Wheut, 58,000,000 bunhels.

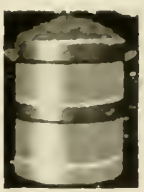

Outs, 180,000,000 bushels.

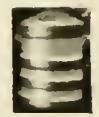

Barley, 68,(000,000 lusklueld.

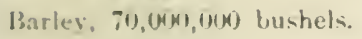

Decrease, 86 per cent.

[]

Rye, J, (x) , oro0 bushels.

liye, 2,000,000 bushels.

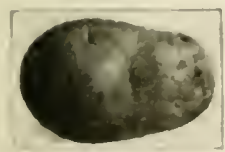

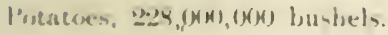

Increase, 211 per cent.

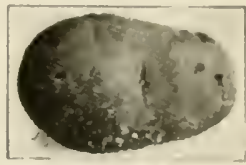

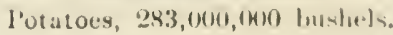





\section{GERMANY.}

1885.

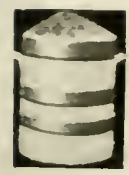

Increase, (ici je.l reml

1913.

What, I11:3,(14), (n)( huchels.

Wheat, 171,(100,0100) busheds.

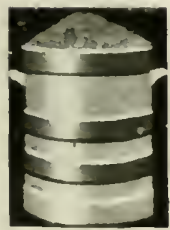

Increase, 175 per cent.

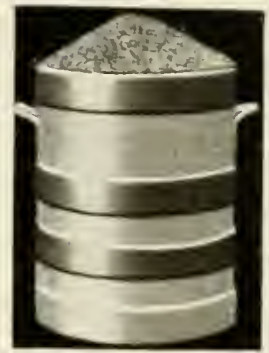

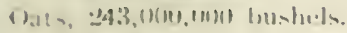

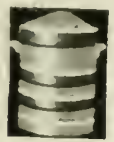

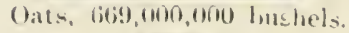

Increase, 73 per cent.

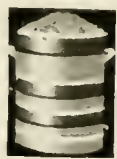

Barley, 97,(x)(1,0(x) buslsels.

Barley, 168,000,000 bustiels.
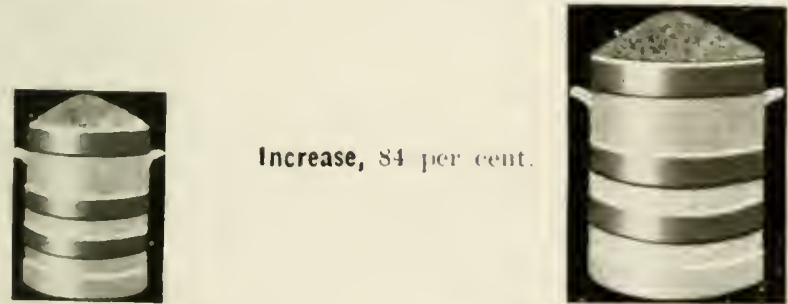

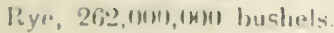

Rye, 481,0000,000 hushicts

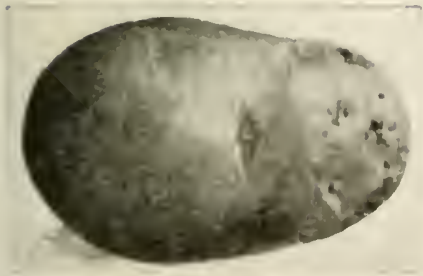

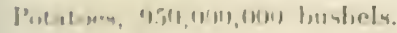

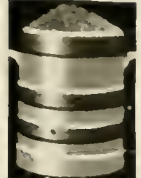





\section{GREAT BRITAIN.}

1888.

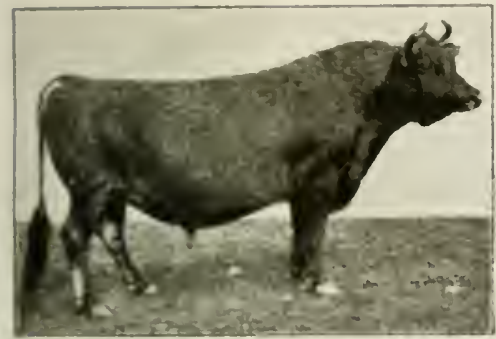

Cuttle, 10,270,0610.

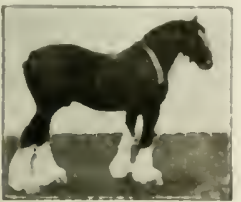

Horser, 1,940,000.

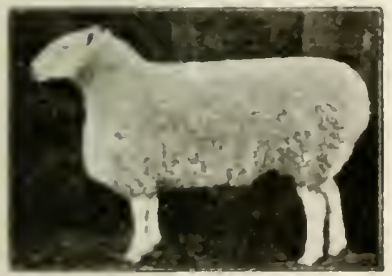

Shocp, 2x,9 H), (k)(s).

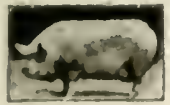

I'Ig4, $3,82011,(5)$,
1913.

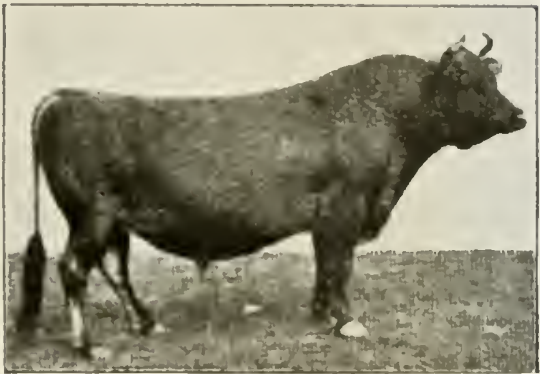

Cattle, $11,914,000$.

Increase, 16 jer cent.

Increase, 3 prer cent.

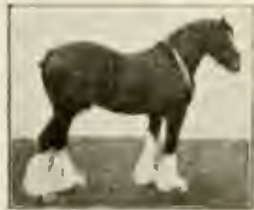

Horkes, 1,999,000.

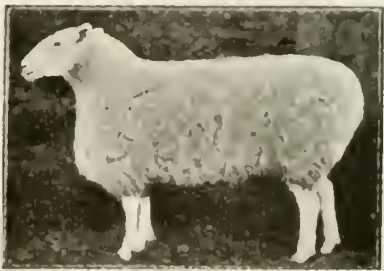

Sheеp, 28,96\%,000.

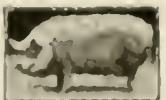

l'igh, $4,(15.5,800(1)$ 



\section{GERMANY.}

1913.

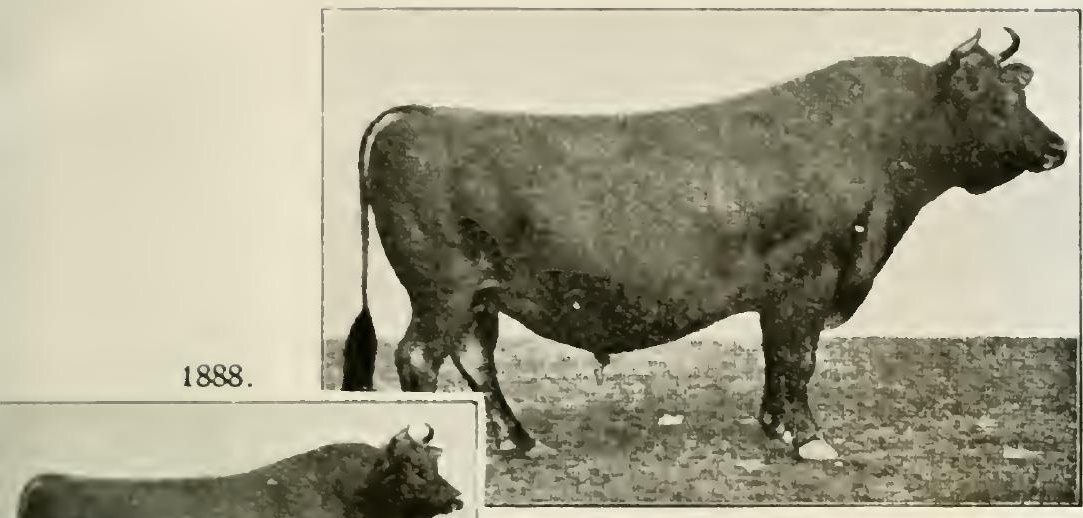

('at (1), :21),15:2,(11)().

Increase, 1:31 frer cent.

Catcle, s, ifu, (num).

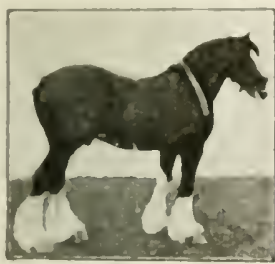

Increase, it pes cent

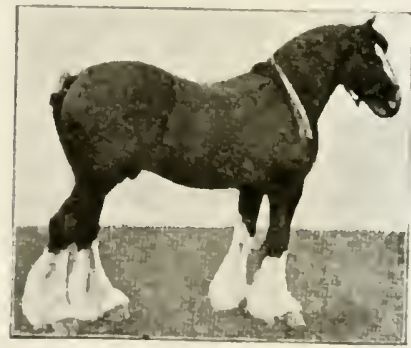

Iformes 2,4:11,0019).

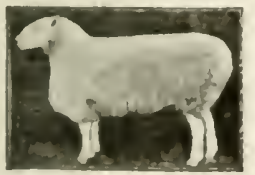

Hornes, $4.52: 3,10014$

Decrease, dil per cent

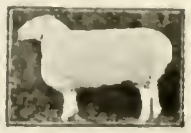

Sherefr, 5,8113,1100

Sheepl, 16,701),(1)(4)

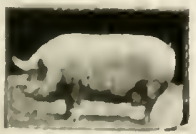

Increase, $27 !$ jer cent

l'(4)

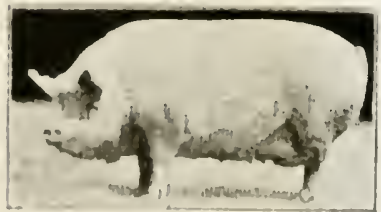

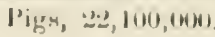



bushels-their production was more than six times that of ours.

Whilst British crop production has actually declined during the past 25 years, that of Germany shows an annual increase of $f_{1} 120,000,000$ in value by the end of the period. Yon Scherwin Lowitz ${ }^{1}$ estimates that the annual value of Germany's agricultural produce approx-

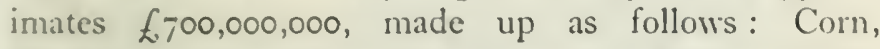
$f_{1}+0,000,000$; meat, $\oint_{200,000,000}$; dairy produce, $f_{1} 37,000,000$; potatoes and sugar beet, $f_{S} \delta 0,000,000$; the balance being made up of fruit, vegetables, oil, fibre crops, viticulture and poultry products. 'That is :

$£, 00,000,000$ worth of produce off $80,000,000$ acres.

Turning to our 50,000,000 acres under cultivation, we find the production for the 5-ycar period, $1909-13$, as follows :-2

The sale of live stock and stock products $\oint_{1^{1}} 5^{1,000,000}$ II heat and potatocs

- $27,000,000$

$$
\text { Total . . . } £_{178,000,000}
$$

If we add another $\{22,000,000$ for other produce, we get a round sum of about $£ 200,000,000$ as the annual value of the produce of our soil. And it has remained at about this figure for several generations.

'To reduce these large figures to small ones easily grasped, it means that our gross yield from the land comes out at about $£ 4$ sterling per acre.

The German return per acre is much higher than this ; but there is little to be gained by working it out in detail, because elaborate calculations would have to be nade

- Deutichland unter hülocr II ilhulm II.

- Sir Thomas Viddle-tuin's alelress to the Agricultural Society. ('niversity College of Wales, Dccumber 19, 1919). 
to adjust the effect of the differences in the price of the agricultural produce of the two countries.

\section{DIAGRAM III}

This shows how the Ioo-acre unit is cropped in England and in Germany.

The circle represents 100 acres; and at a glance we see how much more, of every main crop, is grown in Germany per Ioo acres than with us. It is only in the case of the proportion under grass that we stand far ahead of Germany. And it is precisely for this reason that the 1oo-acre unit in the United Kingdom only yields, in total produce, about one-half of the produce it does in Germany. Yet remember our soil is better than German soil-our climate on the whole more favourable to agriculture; yet 100 acres in Germany is made to feed far more people than it does here.

Why is this so?

The answer is that the steady advance in production in Germany, apart from her tariff policy, is due to :

(I) The fact that the importance of agriculture to the nation has been fully realized by the Government and the people.

(2) The systematic organization of agricultural education.

(3) The improvement effected in the technical methods of the farming community.

(4) The widespread adoption of co-operation and organized credit.

(5) The comprehensive application of science to the land. 


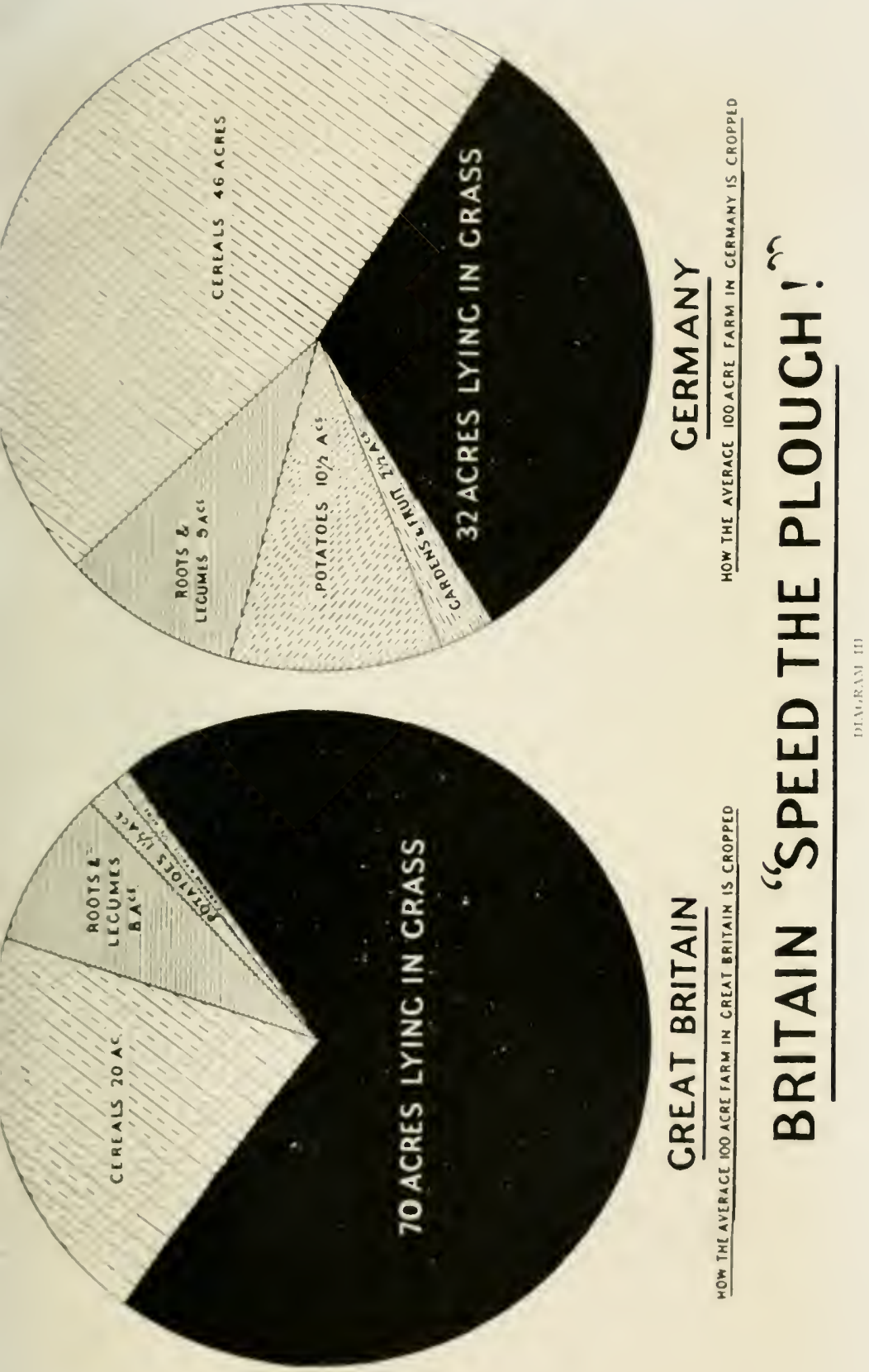



As an example of the effect of the application of science to the growing of sugar beet the following diagram is instructive :-

\section{DIAGRAM IV}

Professor von Rumken of Berlin summarizes the German view of agricultural education in this way :-

"The great progress that agriculture has achieved in Germany during the last quarter of a century is the result of the union of practice with science, and proves that money spent on research and on education brings in a high rate of interest, and is compensited for by increise in land taxes and of revenue from the State railways."

'I'his is an economic fact which, alas, is not appreciated in this country. 'The net result is, as we have seen, that Germany provides more home-grown food per 100 acres than we do: a result due partly to the increase in production per acre, which took place between i $\$ 8 S$ and $I^{1}{ }^{1} 3$, but even more largely to the method of cropping in general rogue.

'The area under corn is large and, note well, the head of live stock carried per 100 acres in spite of this fact is also large-generally larger than with us. With us the whole discussion is one of "horn" (live stock) versus corn; yet the example of continental agriculture proves that both can be developed together. Of this truth we have demonstrations at home if we would only open our eyes to see them.

Lincolnshire is one of the foremost " arable " counties ; yet the head of stock carried on its farms, which are as a rule two-thirds arable and one-third grass, compares favourably with the grass-land farms of the western 
counties. One cause for the widespread (and unfounded) belief that grass land carries more stock than arable is that our agricultural returns of live stock are taken in the summer, when grass is carrying its maximum amount of stock and arable land its minimum. Were the returns made in mid-winter the results would be all in favour of the arable farms, which are then winter feeding their full head of stock.

Hitherto our comparison in production has been between England and Germany; we shall now briefly survey production in some of the other continental countries, not for the sake of making odious comparisons but because it is interesting to see what principles are at work in other countries.

Everywhere we find this in common : the continental farmers rely upon arable land as their mainstay, and consider that they could not afford to have any large area under grass. Grass is not regarded, as with us, as something almost sacrosanct, but just as a crop like any other crop; and it is a crop, and its yield and feeding merits should be considered in relation to other crops.

\section{DENMARK}

Denmark has very little grass land; yet it is certainly the premier dairy country of the world both in regard to the number of cows kept per Ioo acres, and in regard to the yield per cow. Taking everything into consideration, there is no doubt that this is the most interesting country for the Englishman to study agriculturally. The people closely resemble us in temperament; there is the same individualism and independence; yet this has not prevented them from bringing co-operation and 


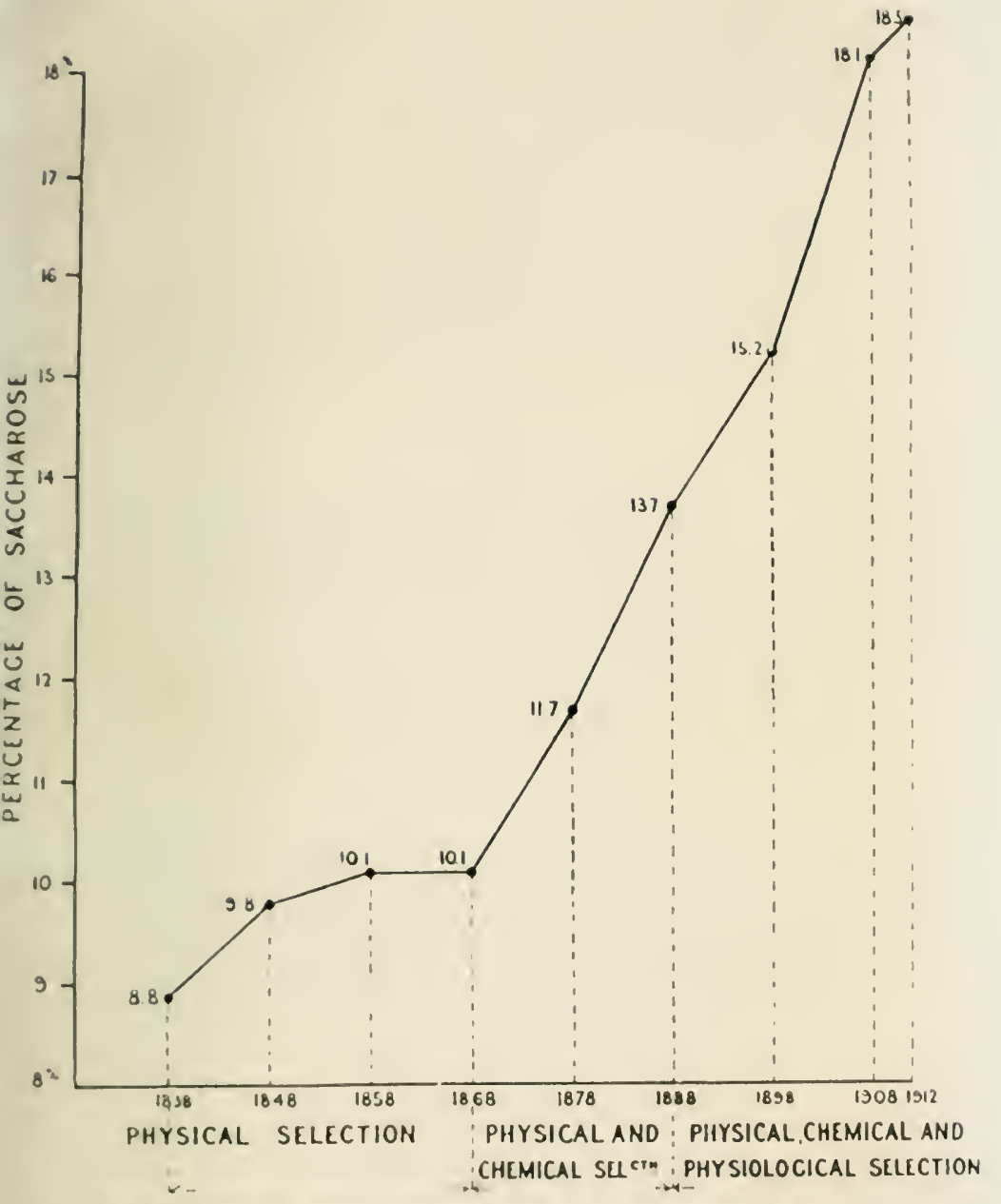

GRAPH showing improvements offected in sugar content of beets. 

organization to the highest level ever reached in the history of agriculture. And it would be hard to find any other rural pcople with so high a standard of education; this is perhaps the greatest advantage they have over us. Inherently our agricultural workers, in the northern half of England at all crents, are at least equal to the Danish; but a large proportion of the Danish labourers own a sufficient amount of land to give them a direct interest in the agricultural industry, and a valuable degree of independence. And the conditions affecting the smallholders are far superior to those existing in this country.

The Co-operative movement had its origin in England about 100 years ago. It has flourished in our tozwns and has reached a degrec of development unequalled in any other country. The Wholesale Co-operative Societies count their membership by millions and the annual turnover is more than $f_{1} 50,000,000$ a year.

The Danes took the idea from us, but with one great difference. They made it a rural movement; the result being that the majority of Danish farmers to-day are members of a Co-operative Society, and the bulk of their produce is sold co-operatively-they are their own middle-men.

The great advantages derived from the full development of co-operation are these : the producer is not only enabled to fix his prices for the produce of the farm at figures which are remunerative in the first case, and much less fluctuating than with us, but he also earns a second profit as a trader - a profit which goes to the middleman here. Though the control of prices is so largely in the hands of the farmers, it is well to note that they have never taken unfair advantage of this. During the years preceding the war the prices of Danish farm produce 
were slightly lower than they were in England-and yet, owing to the perfect organization of the industry, the Danish farmers were earning a far larger profit than their English confrères. Organization does pay.

Perhaps the most important feature in the Co-operative movement was the creation of Credit Societies, which placed capital at the disposal of the cultivator in the form of short term loans. This access to capital was invaluable to the small farmer ; it made him a capitalist, instead of having to struggle all his life against the evil of insufficient capital wherewith to run his holding properly.

People who do not understand the question often point out that the Danish farmers, large and small, have been prodigal in borrowing; but they do not add that the borrowing is sound borrowing, that the loans invariably carry a sinking fund-and that it is good business to borrow at 6 per cent or 7 per cent if the loan earns i 5 per cent or more for the borrower.

The increase in production in Denmark between 1888 and 1913 has been remarkable, in fact, in regard to wheat production, the most remarkable in the world. For its size, Denmark had about the same proportion under wheat that we had in I9I3, and the average yield has been raised from 30 bushels per acre to 40 bushels per acre; and since I9I3 the average has considerably exceeded that figure, having reached 45,47 , and 48 bushels per acre for 1916, I9I7, and I918.

The conditions under which milk is produced in Denmark are extremely good, due chiefly to the fact that the bulk of the milk is sold to the co-operative creameries and they insist upon receiving milk in firstclass condition; and the societies have drawn up strict regulations in regard to the handling of the cows and of the milk. This is far sounder than our system 
of some urban Government department franing and administering regulations.

In Copenhagen there is a special milk supply for infants. It comes from carefully selected farms, and extra care is given to its handling and transport to special depôts in the town; this is done at a profit, although the charge for distribution is lower than it is in this country for milk which is far less satisfactory from the hygienic point of view.

The net result of the perfect organization of the milk business is that the producer makes a good living, and the consumer gets his milk at a lower price than he does in England. There must, of course, be a charge for the distribution of milk, but an addition of 100 per cent to the price received by the producer is out of all reason-yet that was the average tariff before the war.

The houses and farm buildings in Denmark are remarkably fine and form a conclusive testimony to the prosperity of the agricultural industry. The farm-houses are very often as large as small country houses with us, and the modern labourer's cottage is very good, and all are kept in excellent order. Before the war, when discussing the profits derived from farming, I found a very general view that farmers saved and put by in 37 years an amount of capital that would enable them to retire from farming and give them an income equal to their average annual income. Or, to put it in another way, the income derived from the land averaged $f_{4}$ per acre. 'This $\ell_{4}$ per acre would represent, say, $f_{1}$ I os. received as rental ( 88 per cent of the farmers own their land), 10s. interest on working capital, and $f_{2} 2$ as net profit. And in many cases the income from the land was much higher.

'There is no douht that the cultivation of sugar beet, 
which is largely developed in Denmark, is one of the chief reasons for the high condition of the arable land and the increase in the cereal yields. For this crop is an admirable preparation for the subsequent corn crop. But since I9I 5 , owing to the increased cost of labour, Danish farmers are giving up sugar beet to a great extent.

It is sometimes argued that it is because Denmark is a small country that it has been possible to do all this; this, however, does not appeal to me as sound argument. Our eastern counties are comparable in size, and superior in soil and climate, to Denmark; and there is no reason why there should not be a similar agricultural development, at all events in these counties.

\section{BELGIUM}

In this country the average size of the farms is so much smaller than it is with us that it does not afford at all so uscful a comparison as Denmark; also the cultivation, which is much more intensive than in the latter country, reaches a degree of intensiveness to which we can never aspire. Indeed, I do not consider that it would be desirable for us. The holdings are in many cases so small that the amount of work that the cultivator is forced to put into them, to extract a living at all, is more than one would wish to see our tillers of the soil called upon to perform. Yet they not only make a living but succeed in putting by large sums annually, as is shown by the large deposits in the Belgian agricultural bank; also one cannot fail to be impressed by the zest of life of the Belgian smallholders. The study of Belgium teaches us two interesting and valuable lessons ; the first that a country, in which urban industrialism has reached the highest degree of intensity-for the 
output in manufacture, per head of the population, was before the war the highest in the world-can at the same time achieve an agricultural output, per acre, which throws every other country into the shade. The second lesson is that light and poor soils can in a few decades be turned into the most highly productive soil if scientifically handled. It is mainly a question of building up the humus (or vegetable matter) in the soil ; this was done by ploughing in green manure crops, vetches, lupins, etc., and by applying dressings of farm-yard manure far heavier than any of our farmers would think of applying, coupled with the full use of artificial manures.

Before the war the gross receipts for the produce from a little over $4,000,000$ acres (the agricultural area of Belgium) reached the sum of $£ 80,000,000$ sterling; compare this with our $£ 200,000,000$ sterling from $50,000,000$ acres!

There is a third lesson we should learn from Belgium, and that is the value of a dual occupation to the townsman; we have been shown something of this in the results derived from the large development of urban allotments that took place in this country during the war.

In Belgium the system of providing the town worker with a garden, of sufficient size to give hin supplementary occupation when lis main work is slack, has been carefully developed; and over 70 per cent of the Antwerp dock labourers have land sufficient to give them not only healthful occupation when dock work is slack, but to make a valuable contribution of fresh vegetables for the use of their families.

The example of Belgium shows clearly that it is not true that a country must be either inclustrial or agricultural, but that it is possible to achieve the highest 
possible development in both urban industries and in agriculture.

Elementary education in Belgium, as in most of the continental countries, has this good feature that it instils a love of country life and country pursuits ; with the result that a much larger proportion of the children than is the case with us definitely wish to remain in the country. It is easier in Belgium for the schools to do this than it is here, for the children are nearer to the practical work being done on the land; they see their parents at work; the spirit of emulation is stirred, and in the holidays they work along with their parents.

Here the father and older brothers are probably working on a large farm, at some distance it may be from the cottage, and the children in consequence do not grow up in touch with practical work; and when they do go to work for a farmer, at the age of fourteen, it rarely happens that they are directly under the father's influence. Indeed, it is to be feared, the influence to which they are subject is often far from good.

The coming development of the continuation day school, with its consequent prolongation of educational and mental discipline, will prove of untold value to our rising generation if it is run on sound lines.

\section{FRANCE}

It is the wonderful thriftiness of the cultivators of the soil that has made French agriculture what it is; roughly one-half of the population live on and by the land.

The French Government, more perhaps than the Government of any other great couniry, consciously 
determined that the urban side of their civilization should not be developed at the cost of the rural side; and that urban industry should not be over-capitalized while the agricultural industry remained without sufficient capital to develop it.

France has had a protective tariff for gencrations; with such a large proportion of her population producers of primary wealth it could not well be otherwise. And during certain periods of the nineteenth century her increase in national wealth, due to the development of her agriculture, exceeded any record which we can show. Conversely, no other nation can show so large a drop in the capital value of any industry as that which resulted from our agricultural depression.

It is a matter of history that it was the French agriculturists who paid the indemnity to Germany after the war of $1870-71$.

Before 1914 France produced practically all the wheat she consumed; and the annual value of the wheat

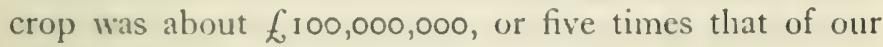
wheat crop. It is interesting to note that during the nineteenth century the price of wheat in France did not fluctuate at all to the extent that it did in this country.

But in regard to actual treatment of the land and methods of husbandry, in general terms we have not much to learn from France; co-operation is not highly developed, and the subdivision of farms has passed economic limits. There are some very good farm institutes in France, but French farmers are not easily influenced.

The French peasantry lead a very hard life, and it is not desirable to build up a class of such peasant proprictors in England; we want something much better 
than this; we want to have our right proportion of small farmers (owning their farms where they wish to), wellhoused, living comfortably, and organized as highly as they are in Denmark or in the Taranaki district of New Zealand.

METHODS OF MEETING THE COMPETITION OF THE NEW WORLD

It was about the year 1870 that the competition of the new countries began to make itself felt in agricultural products.

But even before this the peoples and Governments of the continental countries had begun to devise a "land policy" and to organize the agricultural industry ; they were wiser in their generation than we. And the result of their wisdom was that they were enabled to carry on a steady expansion of the primary industry, in spite of the blast of competition from the tillers of virgin soil.

Whereas, far from expansion, in this country there was a steady shrinkage from I 875 onwards when the depression fairly set in.

In the golden era of our agriculture, I 840 to I 860 , and up to I870, the farmer's working capital was about fio per acre; after the depression and up to the outbreak of the Great War that capital was down to about $£ 5$ or $£_{6} 6$ per acre, taking an average for the whole country, while on a similar basis the continental farmer's working capital was from $£ \mathrm{I} 2$ to $£ \mathrm{I} 5$ per acre with an upward tendency. On the Continent land was attracting capital ; in England it was not.

The competition from the new countries threatened all old countries alike; we adopted one method of meeting 
the threat, the other countries adopted a very different one. Here the landowners reduced their rents to assist the farmers, and the farmers reduced their labour bill and put the minimum into the land-with the inevitable result, decrease in the output from the soil.

We remained unorganized. We stuck to our fouryear rotation of cropping as if it were something inviolable; but we did not adhere to the proportion of land which, when the four-year system was at its zenith, it was considered should be kept under the plough. Four million acres of arable were allowed to "fall down " to grass.

Our Scottish farmers departed from the strict formula of the four-year cropping, and adopting fairly generally a five-year course (under which the clover ley was left down for three years) they weathered the depression far better than we did.

On the Continent the line adopted was: Production per acre must be increased, new systems of cropping must be developed, and the industry must be organized.

I think the comparisons I have given make clear which was the right, and which was the wrong, method.

And we are again at the parting of the ways; one road leads to progress and development, the other to retrogression.

Which road are we going to take? It seems probable that it will not be the question of the price of produce which will be the determining factor-rather that of labour; but it comes to much the same in the end. And if we now go in once more for a policy of curtailing our agriculture, the results will be disastrous.

We did not tackle the situation in 1870 in the right way; to-day we shall have less excuse for going wrong, 
for we possess the advantage of having before us full proof of the advantages of the land policies and more scientific methods adopted in other countries.

Up to 1870 the rest of the world learnt from us ; now for a period we must learn from others-learn, not copy, adapt, not slavishly imitate.

Many people will object to this injunction, being " too proud to learn!"

Rowntree's Lessons from Belyium.

Melines' Le retour à la terre. 


\section{THE SYSTEMI AND METHODS OF PRODUCTION IN THE UNITED KINGDOM}

T $N$ the last chapter certain general results from the British and Continental systems of agriculture were L compared. In this chapter I propose to go into some detail in regard to our methods of production, and to discuss the growing of certain specific crops; this, not in the least with a view to teach the agriculturist, but rather to give the layman and student a certain insight into the cultivation of the land, and to indicate certain shortcomings in our present system.

The layman often thinks that the cultivation of the land is a very simple affair-that any half-trained person who is not fitted for other professions can take up farming, and that agricultural labour is unskilled labour. The very reverse is the case. For every worker on the farm is a skilled labourer in his own line. And more knowledge, thought and forethought are required in successful farming than in almost any other occupation.

About 140 years ago a system of agriculture began to be evolved in this country, under the direction of the great agriculturists mentioned in the historical introduction-a system which is known as the four-Year Rotation.

Taking a given field under this system : in the first year it grew roots (turnips, swedes, mangolds); in the second 
year barley (in which "seeds" were sown); in the third year " seeds" in which clover and rye grass played the chicf part; in the fourth year wheat. Oats were used to substitute, in part, wheat or barley according to the type of soil and season.

This system led to great developments in the United Kingdom, but it was too universally adopted and too slavishly applied.

\section{THE ROOT CROF}

The chief object of the root crop was to clean the land for corn and provicle winter food for sheep and other stock, but there are thousands of acres on which turnips and swedes will not grow with any certainty of profit; this was proved generations ago-but we still persist in attempting to grow them universally.

Mangolds contain a higher percentage of nourishment than any of the other varieties of roots, and provide excellent "bulky" food for dairy cows in winter. Further, they are one of the most certain of crops and should rarely fail if properly cultivated. It is a good sign that the area under mangolds has somewhat increased.

But much more land could profitably be taken from the turnip and swede crop and be given to the growing of fodder or soiling crops ${ }^{1}$ (vide Appendix No. III). A really heavy (or smother) crop of one of these plants most effectively cleans the land-the weeds cannot grow.

There is a further drawback to turnips and swedes where they are fed off by sheep (i.e. where sheep are

1 A fodder or soiling crop is a green crop which is cut and fed to stock, or upon which the stock are " penned " to eat it down. 
brought into the field to eat them as they grow), and that is that often the sheep have not completed their work till latish in the spring, and the ploughing of the field for spring corn (oats or barley) cannot take place until they are out of the field; this results in late-sown corn and often consequently a light crop.

\section{SIIEEP}

The old-fashioned idea still largely obtains that, on certain classes of soil, manuring by the sheep droppings and the consolidating of the land by the treading of the sheep are the best-even the essential--preparation for the barley crop.

I have been told by old experienced farmers that I could not farm certain land without sheep. But nevertheless I have so farmed it for years, and my barley crops have been the best in the neighbourhood!

The fact is that manuring by sheep droppings is by no means scientific; it is hard to secure an even distribution, and an unequal sample of corn results. And the harrow and the roll intelligently used are better than the treading of the soil by sheep.

\section{LEGUMINOUS CROPS}

In regard to the use of leguminous plants, of which white and red clover are the most used in this country. under the four-year rotation one-fourth of the arable land of the farm should be under this crop.

As already stated, the knowledge of the use and functions of the legumine constitutes a definite landmark in agricultural development.

This order of plant life possesses the valuable power, 
by means of certain bacteria, of storing up and using "free" nitrogen obtained from the atmosphere.

If the root of a clover, lucerne, bean, pea or any other leguminous plant is examined, it will be seen that it possesses numerous small round lumps or nodules.

These have been formed by the bacteria which live in the plant, and in return give up the nitrogen they have absorbed from the atmosphere. When the plant dies this store of nitrogen becomes available in the soil for the succeeding crop.

Hence the explanation of the extra heavy crops of mangolds or corn which are obtained when they follow lucerne that has been "down "for a few years.

So that lucerne or white and red clover not only give a rich food for live stock in the part that grows above ground, but their underground growth directly enriches the soil.

Hence it is clear that it is of the greatest economic importance to make full use of these plants.

Unfortunately there is much land which will not grow clovers every four years-it becomes cloversick.

Quite apart from this, there are other soils on which the clovers are by no means a certain crop. And nothing is worse in farming than to have fields carrying only a two-thirds crop, or it may be a half crop.

In the United Kingdom clover, even red clover, is not generally sown by itself but with rye grass and sometimes two or three other temporary grasses-the "seeds" crop of the rotation. Generally speaking, this is a one-year crop-though the mixture can be altered to "stand " for longer. But often a one-year "ley " is allowed to remain down for a second year and the red clover largely disappears-this treatment is not economic. 
One of the most valuable of all the leguminous plants is lucerne, or alfalfa, and its use could be greatly developed in the eastern and southern parts of England; also I believe that it will be found possible to extend its use in parts of the country where now it cannot be grown, provided that varieties of seed can be discovered which will stand the climate. A field can be left profitably under lucerne for four or five years, and then ploughed up ; it is one of the most valuable of fodder crops, and one acre will provide as much food for live stock as three or four acres of average grass.

When the lucerne is ploughed up at the end of five years, it will have stored up nitrogenous manure equivalent to about one ton of nitrate of soda or sulphate of ammonia, which is worth about $£ 25$ to-day and was worth $£_{10}$ to $£_{12}$ before the war.

Nitrogenous manure is the most costly of all manures to give to crops; and as the leguminous plants provide it in the cheapest manner, whatever system of cropping is adopted should be so devised as to make full use of these plants.

\section{FARM-YARD MANURE}

'The other substances required by the growing crops are lime, phosphate and potash. These (save the lime) are all contained in farn-yard manure which, in addition to containing these substances, has a valuable physical effect on the soil ; it adds humus (or body) to the soil. But the value of farm-yard manure depends largely on the way in which it is kept and handled-if loosely cxposed to rain and aerobic action for many months, most of the valuable substances, especially the nitrates, are washed out.

Unfortunately few of our farmers handle this valuable 
manure properly, and millions of pounds worth of its fertilizing properties are lost every year.

Again, our farmers only apply about one-half the amount of farm-yard manure that it is custonary to apply per acre on the Continent. One often sees applications of manure (which has lost half its value owing to bad handling) so thinly scattered on the land that the results therefrom are practically negligible; this is clearly uneconomic.

\section{ARTIFICIAL MANURES}

About one hundred years ago the use of artificial manures began to be understood, again not including lime which has been used for centuries. The value of animal superphosphates (i.e. from bones) was discovered by Liebeg; and Lawes and Gilbert of Rohamsted first discovered how to treat and make available as plant food the mineral phosphates, which are found in deposits in different parts of the world. Much more recently basic slag, a by-product of the iron furnace, was found to be a valuable manure giving phosphate and lime. Then a great importation of nitrate of soda from Chili developed. But as the import of this was stopped by the war our farmers had perforce to use sulphate of ammonia (a by-product of the gasworks) as their main nitrogenous manure.

All these artificials gradually came into use as supplementary to farm-yard manure for certain crops-roots and potatoes particularly; but even to-day the amount of artificials used per acre is far below that used generally on arable land on the Continent. And even more serious, a large proportion of the artificials used by farmers are bought as "ready mixed" manures, whereas the chemicals should be bought separately and mixed at 
home. Very often the farmer has little idea what he is applying; the mixed manure may be good or it may be bad: in any case it is generally far more expensive, at all events per unit value. I have also pointed out that a less amount of farm-yard manure is used; the net result being that our farmers do not put into the land anything like the amount of nourishment for the crops that is given in countries with a highly developed agriculture.

\section{WHEAT}

Now, in regard to the position of wheat in the fouryear rotation, one-half of the arable land is under corn, and one-half of this again should be wheat. But for some decades past the area under wheat has been gradually lessened, oats and barley taking its place, until in the years before the war we find much less than 25 per cent of the ploughed land under wheat. Yet wheat is a basic crop; I shall presently give the financial results when good wheat crops have been grown. It cannot and should not pay to grow crops which come out at 3 quarters to the acre. The average for the country should be 5 quarters. This average would bring us up to the Danish pre-war yield, and it is not advocating the impossible. In many districts where 3 quarters to the acre is the rule, the really good farmes. will be found producing 5 quarters. And this yield should become easier to obtain, with the new and heavy yielding varieties of wheat which are now being produced.

Even at its best, under the four-year rotation, only one-half of the land was under cereals; whereas under a threc-year rotation, in which scveral successive crops of corn are grown, it is possible to have two-thirds of the land under corn. However, when more than one crop 
of corn is grown successively in the same field, full use must be made of artificials if good crops are to be obtained. Last year (I920) 9 quarters of oats per acre were threshed from a field on my farm; this field had been down to lucerne for five years, and then grew a fine crop of mangolds and three crops of corn before the above very good crop of oats-evidence of the powers for enrichment possessed by lucerne, for the soil itself was by no means good.

\section{VARIATION IN ROTATION}

Great modifications in the four-year rotation have already been made by our leading agriculturists. I have even heard of a fifteen-year rotation, but I should not like to specify the exact order ! A five-year rotation has been common in Scotland for some time, and Sir Thomas Middleton gives in detail a six-year rotation also in vogue in Scotland (vide page I04). On my arable dairy farm a three-year rotation is practised in the main. It is as follows :-

First year, roots chiefly mangolds (heavy dressing of farm-yard manure applied); second year, barley; third year, oats. The land is too light for wheat save in one or two fields.

Under this rotation, clover (" sceds") comes every twelfth year; it is sown in the spring corn. The leguminous area is "made up " with lucerne; this is left down four, five, or six years, according to the condition of the crop. If the land is clean, three or four successive grain crops are grown; to grow a grain crop after a grain crop greatly cheapens the cost of production.

As an example of yet another variation Mr. Prout has grown corn, chiefly wheat, consecutively for fifty 
years. The fact is that the good farmer who keeps his land clean is master of, instead of slave to, his rotation; and he can vary his cropping to suit the needs of the year-provided certain underlying principles are observed. The main object must be not only to have a heavy yield in this or that field, but to see that no part of the farm is producing only half crops; also to see that the grass land is producing the maximum amount of which it is capable.

The four-year rotation is still adhered to by our indifferent farmers-it is their sheet-anchor-and were it suddenly abolished they would find themselves in great difficulties.

Nevertheless the time has come to recognize that, for the industry as a whole, the four-course system is no longer necessary: and that a radical change, gradually and scientifically introduced, would improve our agriculture and increase the yield from the soil.

\section{GRASS versUS ARABLE LAND}

Coming now to the main apportionment of the whole farm : in the eastern or corn-growing counties two-thirds was supposed to be under plough and one-third under grass, and in the west and south of England one-third under plough and two-thirds under grass. This gives only a very rough idea of the proportion of arable to grass, for there were infinite variations according to the nature of the farm. But this is definite, even when the area of arable is largest: the proportion of grass land to the whole is larger than on the Continent. And here we cone to the root of the whole matter; not only are there methods of handling arable land which will profitally produce more food than the four-year shift, 
but we do not handle our grass land properly and so we lose on both counts.

Diagram No. III, page 78 , shows at a glance the case of grass versus arable, and I again make certain comparisons with the situation in Germany because it helps us to understand the situation here. There is more than twice as much grass land, per roo acres of cultivated land, in the United Kingdom as there is in Germany. Let us examine the reasons for this.

(I) The question of climate is an important factor ; the climatic conditions are more favourable for grass production here than anywhere in Europe. But unfortunately it does not follow that our grass land is of an uniformly high quality; quite apart from the fact that there is much land in England under grass which is less suited to grass than to arable cultivation. Even in parts of the country which from every point of view are rightly grass land districts, there is much poor grass-poor owing to neglect and bad farming.

(2) There is no doubt that for many years the continental farmer has realized that arable farming is more profitable than grass land farming. This is a point that the English farmer does not yet fully understand.

(3) Arable farming requires more capital, and a greater annual expenditure than grass farming; and whereas the German farmer (and indeed the continental farmer generally) was quite willing to embark upon this expenditure, knowing full well that his Government and his nation would see that he was not let down, the English farmer had no such assurance-but very much the reverse.

(4) There is no doubt that the inclination of the English farmer has always heen towards grass rather 


\section{MFTHODS OF PRODUCTION}

than towards arable farming; and we have seen in our brief historical survey how, through all ages, the Government has attempted to modify this inclination.

It is a natural inclination; large numbers of our farmers who are not particularly well-trained or educated, and who are content with their lot, only wish to make a bare living-and this they can do off anything from 50to 200-acre farms where grass dominates, in the west and south-west of England.

Grass farming does not require the mental and physical effort necessary for successful arable farming; and so we see a large number of farmers of this type who drift along on their grass farms, generally with a neat little house and just sufficient to sustain life, and there is an end of it. 'The grass land is not properly handled, and it is carrying live stock of no very high order. Such land is not being put to the full economic use from the national point of view, and the usefulness of such farmers as citizens is open to question.

(5) A new factor has come into the problem within the last few years and that is the question of labournot so much from the point of view of the wage as the amount of work each man puts in during the working hours. If the prices for arable crops are properly adjusted the farmer can pay a good wage; but no farmer can farm against a general slacking off of effort on the part of the men who work for him - this is an increasingly serious point. If it is true that there is a general decrease in "effort output" per man, this will become the determining factor in the retention of land under the plough or in its being laid down to grass.

Having stated the chief caluses of the predominance of grass in the United Kingdom, let us now consider whether this predominance is to the benefit of the nation 
- or whether our national necessities do not require an apportionment of grass to arable more nearly approaching that of Germany? In general terms 1000 acres of grass land, and the stock which it carries, gives employment to one-third the number of men employed upon 1000 acres under the plough.

So that for every 1000 acres laid down to grass less labour by two-thirds is employed, and the other twothirds are driven from the land.

Nationally, this is perhaps the most serious point of all ; and bound up with the national point of view is the imperial one. Imperially, we must have an overflowing agricultural population; so that each year we can send out to our Dominions overseas a certain number of men born and brought up on the land, without depleting our supply of cultivators at home.

The second point is that the land must be made to yield the maximum amount of food for the nation. And land under the plough feeds more people than does even the best grass land. Here are the facts as stated by Sir Thomas Middleton, late of the Ministry of Agriculture :-

"Taking the figures for the five-year period I909-13, it is apparent that live stock farming in the United Kingdom was paramount. It may be shown that $36,000,000$ acres were devoted to producing meat and milk as against $2,950,000$ to the growing of wheat and potatoes.

" The sales of live stock and of stock products totalled some $f_{1}, 5_{5}, 000,000$ per annum, while wheat and potatoes produced $£ 26,750,000$ only.

"The entire food supply of our live stock is not, however, produced from the soil of the country. 
"We import feeding stuffs for which the farmers paid annually $f, 32,000,000$ in the 1900-1 3 period.

"These feeding stuffs have considerable manurial value, and we may write off $£ 6,000,000$ as the sum due for manure by land used for raising other saleable products than live stock.

"This would indicate the value of live stock and live stock products of the United Kingdom to be $\oint_{1} 125,000,000$ per annum in the period 1909-13. It may be remarked in this connection that the trade in exporting cattle and sheep, though valuable to those engaged in it, was relatively very small in the period under review."

This is an important point to bear in mind as there has always been a tendency to exaggerate the value of this branch of the industry, which carries also this disadvantage to English agriculture - that the export of our pedigree stock has had the effect of improving the position of our foreign competitors.

To return to Sir Thomas Niddleton :-

"Let us now turn our attention to examining our returns per acre in money and food which we get from the land of the United Kingdom. When for 'total value' we substitute 'value per acre' there is less reason for the complacency with which we have hitherto regarded the results of our live stock farming (and live stock farming is grass-land farming).

"When a deduction for imported feeding stuffs has been made we find that the receipts from the live stock come out at about $69.5 \mathrm{~d}$. per cultivated acre, as against $182.9 \mathrm{~d}$. per acre realized by wheat and potatoes.

"Coning to the relative energy value of the different foods produced it may be shown that 100 acres of an 
average yield would provide energy for the following number of persons :-

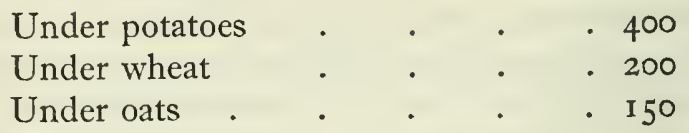

Under mangolds converted into meat . $4^{\circ}$

Under meadow hay . . . $\quad$ I2 to 14

"If, further, we assume a farm to be worked on a six-course rotation, wheat, potatoes, oats, roots, barley, clover-it may be shown that per Ioo acres energy for about $1_{50}$ persons could be produced; on grass land of average quality, half producing meat and half milk, the corresponding figure would lie somewhere between fifteen and twenty.

"The changes in our system of farming in the past fifty years have had one result which I believe that few of us have realized. It is that, in spite of the great advance made by British farmers between the close of the Napoleonic wars and the depression of the seventies, the population we were feeding from our own soil in the period $1909^{-1} 3$ was little greater than it was a century ago, and substantially less than it was seventy-five years ago. In the period I80I-10 the soil of the United Kingdom fed $16 \frac{1}{2}$ millions. In the period I $83 \mathrm{I}-40$ about $24 \frac{1}{4}$ millions, while in $1909-13$ the number was about I $7 \frac{1}{2}$ millions."

These are the figures that deserve careful study from the national point of view. As a result of this study only one conclusion can be arrived at, and that is that a larger proportion of our land should be under the plough than is at present the case. This does not mean that all our grass land should be ploughed up, or that our very best grass land, which justifies its existence, should be 
touched. But it does mean that the proportion of grass to arable land, per 100 acres, should be 45 or 50 acres instead of the present 72 acres; even then we should have more grass per 100 acres than Germany has, and quite rightly so.

Again, ploughing up this acreage of grass does not mean that we should have an "up corn and down horn" policy; for with that increased area of land under the plough, properly managed, we should have more and not less live stock. Taking all existing conditions into consideration our motto should be " Up corn and up horn," as Lord Lee, then Minister for Agriculture, said when speaking at Gloucester in April, 1920.

So much for the national point of view. Turning to the economic side, let us consider what is the relative profit earned by the farmer from plough land and grass land respectively.

First, it must be admitted that it is very difficult to get much data; for until quite recently little attention has been paid to careful book-keeping, or to tabulating the results where good accounts are kept. Within the last two years or so an official "Costings Committee" has been set up, but its work is not yet sufficiently advanced to be of great practical use ; also the fact that this committee has been at work only during a time of abnormal conditions and prices, resulting from the war, means that we cannot safely base calculations upon its interim report. 'This will be referred to later.

For my present purpose the paper read at the Surveyors Institution in 1912 , by its then president Mr. Edward Strutt, gives the best figures I know of ; it shows clearly the profit and loss on large acreages, and over three separate periods, of the main crops on a mixed farm. It must be remembered that the land in question is 


\section{THE LAND AND ITS PROBLEMS}

situated in an eastern county, that it is in an arable rather than a grass land district, and further that such grass as there is is not first-class but just average, or perhaps somewhat below average.

As Mr. Strutt manages and farms the area with which

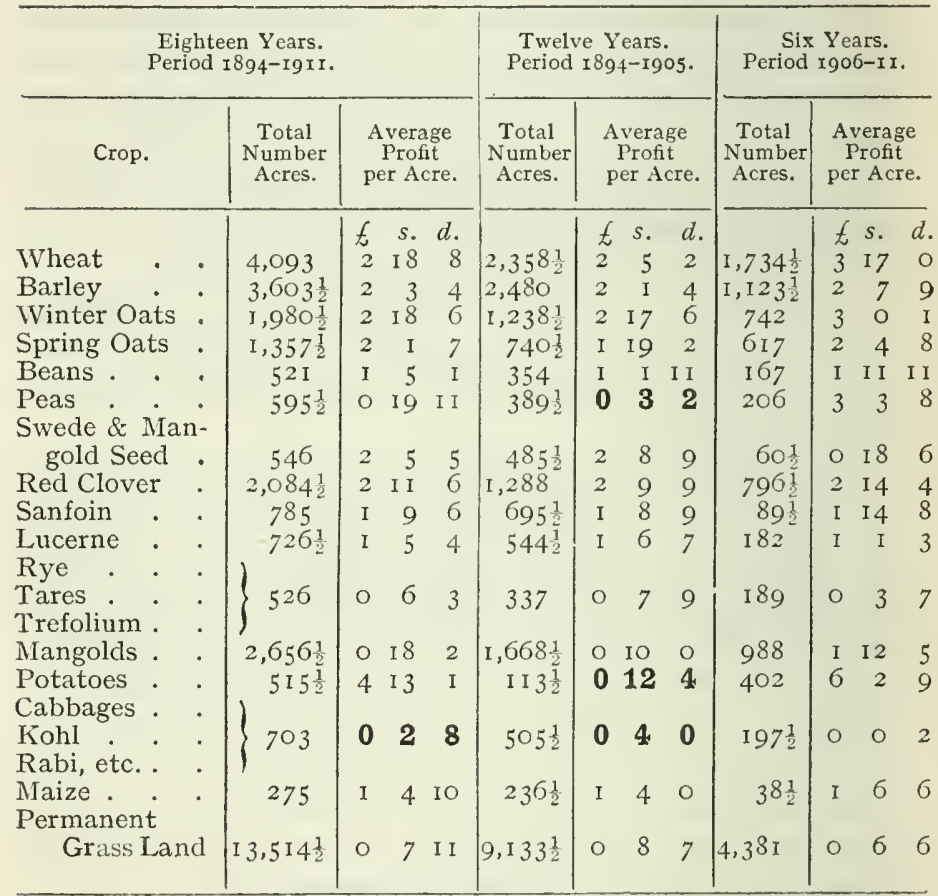

Note.-Losses are shown in heavy type.

we are here concerned on behalf of a company, the bookkeeping is careful and accurate ; and, in passing, it may be noted that the shareholders have received a very good rate of dividends throughout the whole period. 
The accounts given here "represent two farms of roughly 2000 acres of which three-fifths are arable and two-fifths pasture, the arable land of a mixed quality, erring rather on the heavy side.

"Opposite are the net financial results per acre over (I) the whole eighteen years; (2) the first twelve years; and (3) the last six years. The average profit per acre shown has been arrived at after charging all expenses, including rent, rates and taxes, but excluding interest on capital.

"The following figures show the result of stockkeeping on the same area of land :-

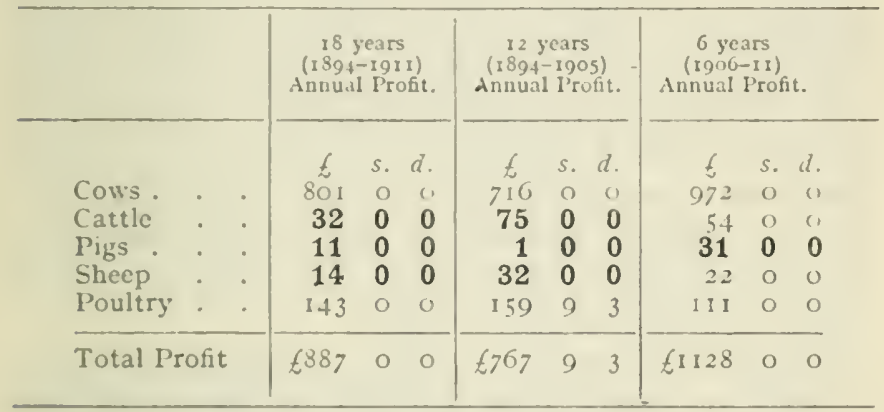

Note.-Losses are shown in heavy type.

"It will be observed that cows and poultry after being charged with every expense have been profitable to the farm. Taking the whole period, cattle, sheep and pigs have shown a slight loss.

"During the eighteen years the cows kept have averaged about 450 , so that, even in their case, the net profit each year only amounted to from $43 /-$ to $45 /$ per head.

"The net profit from the arable land over the whole 
eighteen years has been $£^{2} \mathrm{I}_{5} \mathrm{~s} .7 \mathrm{~d}$. per acre, and from the grass land during the same period $7 \mathrm{~s}$. IId.

"It is especially interesting to note that the wheat crop grown in the dry climate of the east of England has proved itself the most profitable; and it would seem to be possible, if the prices of the last six years should be maintained, that a far larger area of wheat might be grown than is now the case."

It should be noted that, during the period when Mr. Strutt's figures show that wheat was the most profitable crop, the practically universal opinion amongst farmers was that wheat growing did not pay, but that raising live stock did. Personally, I began my farming operations on a large scale in 1903 , when I had to take over 4000 acres of "mixed farm " land as they stood; and one very soon realized from the account books that the live stock department was showing a loss, while there was a good profit from cereals. In general terms, the book-keeping on farms is not accurate enough to show which department is making a profit, and guesses on such a subject are of no value.

It should, however, be clearly recognized that there are large numbers of grass-land farmers who do not know how to handle arable land properly, and who would in consequence make little or no profit if they attempted to do so; also that, while the potential margin of profit is greater from arable than it is from grass land, in the case of the poor farm that margin is susceptible to greater variation than is the case in grass-land farming.

Again there is little doubt that where a nation is hostile to, or neglects, the agricultural industry, the grass-land farmer can face such a situation better than " the arable farmer."

But it should not be necessary to take such a situation 
into consideration; and in every country, where the importance of agriculture is realized, no doubt exists in the minds of the cultivators in regard to the superior profits derivable from plough land.

\section{THE SOILING SYSTEM}

Another interesting demonstration is that of the Harper Adams Agricultural College (Newport, Salop), which for several years past has been carrying out an experiment in dairying on arable land-that is, keeping the cows entirely (apart from cake, etc., purchased) upon foodstuffs produced from plough land. And for the sake of comparison they have kept a similar number of cows on good grass land. The results are most interesting and of special importance, because they come from a typical good grass-land district.

In fact, this system of growing soiling crops is more suited to districts with a fairly heavy rainfall than it is to the drier eastern counties; and it provides a sound and profitable way of keeping land under the plough in districts where extensive cereal growing would be perhaps too risky. Here are the results :-

Fifteen acres produced fodder crops for thirteen cows, the bulk consumed by the cows as green food, direct from the field, the rest turned into hay to provide dry food. In addition the cows received about $4 \mathrm{lb}$. of cake a day.

In $1917,499+4$ gallons of milk were obtained per acre, against 199.5 gallons from similar land in grass. And this is really good grass land; the average yield of milk per acre of gralss for the whole country does not exceed 120 gallons. We hear much of our wonderful English 
grass ; as a fact, the area of first-class grass is very small -probably only 500,000 acres.

In 1918 the yield was 548 gallons per acre, or nearly three times that obtained from land in grass. A great advantage is that, under this system, the flow of milk is not subject to the sudden variations that occur in the case of cows feeding on grass; and another is that the yield of milk is heavier in the winter months than it is in the summer.

The cost of feeding under this system is practically the same all the year round; and if farmers will only take to it, it will prove of great assistance in the solution of that serious problem-the winter milk famine.

The net profits obtained were $£ 20$ os. $3 \mathrm{~d}$. per acre, which are enormous, and which are naturally larger than would be obtained from a large farm worked on the same system. These profits are arrived at after deducting all costs, including interest at 6 per cent on capital and ro per cent depreciation.

In practice, and when once organized and established, this system does not involve any great increase of labour over the ordinary mixed farm.

We stand in need of more demonstrations of the value of this system, in different parts of the country, if we are to wean the farmer from his undue dependence upon grass. It is extraordinary, when one looks into it, to find how little it is realized even amongst farmers that ordinary grass is only first-class food during three months of the year. I shall include the whole of Mr. J. C. Brown's Report in the form of an appendix ; and I here quote only his concluding paragraph, with which I am in complete agreement, and which contains a great 
economic truth: "This system, if adopted, will undoubtedly prove to provide a valuable check to the Law of Diminishing Returns. And it is one of the chief duties of the research worker to discover checks to the Laws of Economy.", 1

1 Vide Appendix No. III on sorting crops. 


\section{SMALL AND LARGE HOLDINGS}

7 HE question of the relative production of grass and of arable land has been dealt with in a

1 preceding chapter. In this chapter the relative production on small and large holdings will be considered; but in the case of small holdings the question of the proper proportion of grass to arable comes in, in some ways more strongly than in the case of the large farm. For, to justify its existence, the small holding should produce more per acre than the large farm-in other words it must be more intensively (or highly) cultivated-but grass is the least "intensive" of all crops. This does not mean that there should be no small grass-land holdings; from 5 up to 20 acres of grass can prove invaluable to a man who has some other occupation and whose holding is supplementary. It is the full-fledged small farm of 30 to 50 acres which should have the maximum possible amount under the plough.

At the outset let me say that I do not take the view that England should become a country of small holdings, any more than I would say that the large farm of several thousand acres should supersede farms of all other sizes. There is room for the development of both, and we shall probably see this development in the next thirty years or so.

In some parts, the number of medium-sized farms of 
from 100 to 300 acres will probably be reduced, to make way for an increase in small holdings and in large farms.

From the national point of view the smallholder is important because he gives solidarity to the agricultural population-we require a larger number of people with a direct interest in the land; and in these days of labour trouble, the smallholder and his family are generally selfcontained and can dispense with outside hired labour.

The definition of a small holding is " a farm of 50 acres or under, or whose rental does not exceed f.50 a year."

When small holdings are talked about, people generally think of the small holdings created by the County Councils under the Act of 1908 . Little is heard of the great number of old-established small holdings, that have battled with adverse circumstances for many generations. It is typical of a land-ignorant people like ourselves to pass over, and leave unassisted, a great existing class of agriculturists; and to spend large sums of money in placing a few new men on the land, under a system and under conditions which are far from satisfactory.

How many people realize that of the half million farmers in the United Kingdom no less than 230,000 are smallholders? How many realize that from I 908 to I9I4 the combined effort of all the County Councils in England resulted in the placing of only 16,000 people upon the land? We must remember that of these 16,000 only some I500 were placed on newly equipped small farms. The shortage of houses in the country was an everincreasing evil ; yet this Small Holdings Act only brouglit about the erection of 1500 new houses and buildings!

But the legislation was passed, and the stupid people who had been fussing about giving access to the land to the vast numbers who were supposed to be clamouring for it were satisfied. The Small Holdings Act should have 
been regarded and administered as a " Home Settlement Act"; Sweden shows us what can be done in that direction in an old country.

From start to finish no thought was given as to how, and under what conditions, the men should be placed upon the land; and, even worse, no thought was given to the 230,000 existing smallholders and the need of improving their condition! Our land "reformers," chiefly townsmen, with their parrot-like cry of "access to the land," were too lazy to study the problem of small holding settlement, or to see for themselves the results of organized settlement in countries where the right system had been adopted.

The motto should have been " make good before you extend"; and had the Government, acting upon this principle, set out in the first place to organize the existing smallholders and to create for them conditions as good as exist in other countries, the nation would then have realized the economic and social possibilities of small holdings. And newly established smallholders would have been joining a highly organized and flourishing community. In fact, if this course had been adopted, the small holding section would have increased and developed as a natural consequence; there would have been sound growth, instead of artificial growth.

All this is not only a case of "should have been," it is the practical issue of what "can be" to-day, and this side is of greater importance than ever before. We wish to increase the yield of the land : the yield of the existing smail holdings can be enormously increased.

At the present time it is impossible to create new small holdings on an economic basis, for the cost of building and equipment is prohibitive ; let us, therefore, concentrate on the existing small holdings. This is 
unanswerable logic-but, alas! we are not a logical people !

I have in mind a district of small holdings (and there are many such districts); at the present moment they are not being cultivated to the national advantage; the smallholders are doing the best they can, under the circumstances, and are putting up a splendid fight against adverse transport and marketing conditions. Yet it would not cost a large sum of money to turn that district into a demonstration of a flourishing small holding colony.

Organized transport by means of motors, and in some cases light railways, would put the smallholders within reach of markets.

Organized marketing by means of co-operative societies would free the smallholder from the "strangle-hold" of the huckster who to-day handles his produce, and takes much of the profit that should go to the smallholder.

Organized superision and expert guidance would show the smallholder the advisability of altering his system of cropping; and he would be a willing learner if rightly approached. Instead of having much of his land under grass (generally an uneconomic crop for a smallholder) and raising sheep and beasts of rather indifferent quality, he would go in for arable land dairying. And we must look to the smallholder more and more to produce the much-needed increase in our milk supply. It is becoming increasingly difficult for the large dairy farmer to get milkers, and consequently many are going out of the business.

Organized access to capital would enable the smallholder to effect these changes, which would result in trebling the production from his loolding and doubling his income. 'This is not an exaggerated statement; 
there are plenty of examples to show what can be obtained from the small holding properly cropped and run. Incidentally, the question of access to capital has received far less attention in this country than on the Continent ; yet it is the key which unlocks the door to the land and its successful cultivation.

In my criticism of the small holdings created between I 908 and I9I4, I do not wish to imply that the procedure of the County Councils has been altogether bad; as far as their own interests are concerned it has been quite good. The County Councils have lost very little money over small holdings; the smallholders have met their obligations well, and the amount of rent in arrear is negligible. I am not here discussing the post-war situation.

It is when we come to the interests of the smallholders themselves that our system breaks down; for, speaking generally, they have not been settled under right conditions, and in consequence they are not as effective producers of food as they should be-this to the nation's disadvantage as well as their own. In other countries the Governments have realized, much more clearly than we, the importance of the smallholder in the agricultural community; and they have taken sound measures to secure the creation of conditions favourable to him. This has not involved spoon-feeding, or paternalism; the smallholders were simply given opportunity and encouragement to organize and improve their own conditions, and transport was provided as a matter of course and as a national affair.

In parenthesis, let me say that placing smallholders on the land is "settlement," and creating the right conditions for smallholders is "scientific settlement"; but it was only when our Government was faced with the 
problem of dealing with ex-service men that they, for the first time, gave any consideration to the problem of "organized" or "scientific" settlement. As the result of considerable pressure, the Government appointed the Verney Committee in 1916; and the report of this Committee (cd. 9079) is noteworthy, in that it is the first to lay down the principles of sound settlement. Its recommendations have been more or less embodied in the "Settlement (Facilities) Act," and rather less than more, they have been or are in the process of being carried out.

Further details are given in Appendix No. IV.

There is much variety in the types of small holdings, as also in their size. Technically, a holding of under 5 acres is an allotment, though in fact the majority of allotments are of $\mathrm{I}$ acre and under.

Market garden holdings would be, as a rule, of under 5 acres; in France or Belgium, with their wonderful intensive methods of cultivation, one acre is considered the economic size, and a skilled man can make from $£ 80$ to $£ 100$ net per annum (at pre-war rates) off such a holding. Next in size would come the combined market garden and fruit holding, averaging about ro acres, with tree fruit or bush fruit.

The fruit farm is planted with standard apple, pear, plum, or cherry trees, as the case may be, and often with raspberries, currants, or gooseberries between the rows of trees. This type of farm may range from 20 to 50 acres in size, 30 acres probably being about the average. When in full bearing the gross yield can be $£_{80}$ to $£_{100}$ per acre, and more in exceptional cases, and one has known men to clear $£_{40}$ per acre in a good year. At a very moderate estimate the profits from this type of farm should average $\mathcal{L}_{20}$. But profits will always depend upon the 
human factor-one man makes good where another fails. The Evesham district in Worcestershire is one of the best examples of this type of holding, and the development there during the last thirty years has been remarkable. Wherever there are holdings of the above types in considerable numbers - and the whole aim ought to be to concentrate them-there should be fruit and vegetable drying plants, and jam, bottling, and fruit pulp factories ; only so can prices be steadied and the effect of gluts avoided.

The small farm. On grass land, holdings range up to 50 acres (generally 30 to 50 acres where the holder counts on making his livelihood from the land) in the western half of England; and a very fine development of the grass-land dairy holding, averaging about 30 acres, is to be found in Cheshire and Lancashire. But even here a larger area might be advantageously under the plough. This would reduce the large purchases of food stuffs for the cows ; and one of the axioms for the smallholder is: "Be as self-contained as possible." The Lancashire smallholders are progressive and have responded well to the efforts of their County Council to give them the full advantage of expert guidance in all matters relating to the land. This County Council expends a larger sum on agricultural education than does any other County Council, and the beneficial results are clearly seen.

One word more in regard to small grass-land holdings. It is not intended to rule out the grass holdings altogether, for when they are properly looked after they are justifiable. A few acres of grass land may be a great boon to the agricultural labourer, enabling him to keep a cow and earn extra money with less work than he would have to bestow upon an arable holding; it often happens that 
the wife and children attend altogether to the cow and holding, while the man is working for a wage.

The carrier and the carter really require some grass land, and the small village tradesman too is often keen to have a field. But this class of holder is prone to regard his land just as a convenient run for his horses, or an odd beast or two, and to neglect it. These men have a right to have this land only if they can tend it properly.

It is well to bear in mind that there are two main divisions into which smallholders fall-the first, those whose aim is to make their entire living off their farm ; the second, those who are more or less dependent upon some other source for their livelihood, and who regard their holding as supplementary.

There are districts in which a man would find it hard to make a living solely from his holding, and yet where it would be a most profitable adjunct to some other occupation. In other words, there are cases where a dual occupation is more profitable than a single one ; in many countries the system of dual occupation has been much more developed than with us. 'To give an example, afforestation work and work on a small holding make a most happy and profitable combination.

In the eastern half of England the small holdingsagain averaging from 30 to 50 acres largely of arable land-produce a certain amount of corn (in some districts specializing on potatoes) and beasts and some sheep, rather than cows. And it is this type of farm that should be gradually transformed into arable dairy farms, and the necessary conditions created to secure their success. For the farmer with less than 50 acres cannot afford grass as a crop in the eastern counties. He should go in for lucerne and other fodder crops that may suit his 
locality. I am afraid the majority of smallholders of this type do not earn an income of much more than $£_{\mathrm{I}} \mathrm{a}$ week in cash, plus the home-grown food they consume, and a rent-free dwelling. This cannot be considered an adequate return for the "effort output" on the part of the man; in Denmark on similar holdings the small farmer earns at least double this cash income. (These figures are all on a pre-war basis.)

The first step necessary to secure the potential development of the small farm, whether on grass land or on arable, is to organize the " bulk " handling of its produce ; by the establishment of the creamery, dealing with the distribution of whole milk, or turning it into butter, or cheese, as the case may be ; of the bacon factory and of the poultry and egg depot-for pig and poultry keeping should be important side issues on all small holdings. The first object of collective marketing by means of the factory, or depot, is to provide the machinery to undertake all the business side for the smallholder. The smallholder's whole effort should be to produce food by the direct labour of his hands, and unlike the large farmer he has not the time to attend markets, nor the business training necessary to meet professional dealers on equal terms. That is why the business side must be done for the smallholder.

It is quite useless to expect smallholders themselves to start these factories and depots on a co-operative basis. They have not the necessary capital or knowledge ; and merely preaching co-operation is not effective. Far better is the Australian method, where the Government erects the factory, manages it until it is well established and paying its way, and then encourages the smallholders gradually to buy the Government out, and to own the concern co-operatively. From the outset the 
smallholders appoint a committee of management to work with the factory manager, in order to train for the work. 'This applies not only to the factories and depots, but to all stores and other agencies which do business for the group of smallholders.

Although it will be to the national advantage to see a great development of dual occupation, with men settled on loldings from which they do not draw their entire livelihood-still our main object should be to see, not only that the bona fide smallholders do not decrease, but that their numbers are increased where and when possible.

The present cost of building and equipment is so great that it would be wise to check the creation of small holdings for the next few years - not only in the interests of economy, but of the holders themselves-for the present cost overweights them in regard to capital. And apart from the present cost, even before the war I always felt that the expenditure on buildings was too great; a man starting upon a new small holding in England should be willing to go through the same housing phases as the settler in the new world, first the temporary shack, and then the good cottage. And many men, especially if unmarried, would be quite willing to do this ; but our housing rules and regulations permit it not. Too high a standard has been set, and this means too great an initial capital expenditure; which in the end will prevent, or delay in any case, the smallholders' upward progress.

When circumstances again permit of the creation of new small holdings, we should bear these points in mind ; and meanwhile we can be organizing the business side, putting together the framework for turning all our existing smallholders into more efficient producers. 
This will make our area of land go further-for where an Englishman asks for 50 acres, the Dane asks for 25 and makes more of them, and earns a larger profit, than the Englishman from his 50 acres.

We have now arrived at a point when we can discuss the relative economy of the small holding in comparison with the larger holding. On the one hand there is the out-and-out advocate for small holdings-generally a townsman and a theorist, who knows nothing of the economy of either small or large holdings, and who has an impracticable vision of all the land of the United Kingdom being divided up amongst smallholders. On the other side you have a large body of people with a practical knowledge of agriculture who, while they admit that the maintenance and even the development of small holdings is desirable on social and national grounds, say that they are not and cannot be economic.

That small holdings are not altogether uneconomic, even to-day, is clearly proved by the fact that there exist some 230,000 old-established small holdings; they would not exist at all unless the men were making a living, and they certainly would not be making a living unless they were clearing more per acre than the average profit per acre obtained on the larger farm. Even in the present unorganized condition of our agriculture (and the smallholder suffers from this want of organization far more acutely than does the large farmer) such figures as are available tend to prove that our small holdings, in spite of the present unsatisfactory conditions, produce more food per acre, and a larger profit per acre, for the cultivator than do the large farms. In no continental country would it be necessary to adduce proof of this, for it is an accepted fact. 
The great difficulty is that most of the opponents of small holdings are men definitely interested in large farming, who fear that an increase of small holdings will cause inconvenience to the large farmers (which will be the case sometimes); or they have had striking proof of the bad condition and handling of certain small holdings they know intimately, and they generalize from this experience. In some strange way they pass over the fact that they know of equally bad management of, and of bad results from, large farms. There are numberless farms of 300 and 400 acres managed as badly as can be; yet one does not hear it generally said that, in consequence, there should be no farms of this size, or that they are uneconomic!

Unfortunately most of the members of the County Council Small Holdings Committees belong to the type just described. Further, as a rule they are men without great vision; they do not realize how unfavourable to smallholders are the present conditions, nor the revolution that the creation of good conditions would bring about.

We are indeed in an unfortunate position-our urban visionaries are without practical knowledge, and our practical men are possessed of little vision!

As a rough basis for comparison reference may again be made to the statement that the average grass production per acre in the United Kingdom was f.4 sterling before the war. 'Taking an example of the most intensive cultivation, land under the French method of market gardening produces over $£, 500$ worth of vegetables per acre per annum, giving quite a fair margin of profit$£ 80$ to $£ 100$ a year. Under ordinary English market gardening the turnover would be about $f_{1} 100$ a year. In the case of cultivation under glass a yield of $\oint_{1000}$ a year gross per acre has been obtained in different 
places I have visited-in Essex and Jersey for example-.. and the net profit ranged from $\oint_{2} 200$ to $f_{4} 400$ per acre. But for cultivation under glass the initial capital outlay is very great, and expert knowledge of a very high order is necessary to secure success. The present high cost of equipment would make development in this direction impossible.

The capital outlay for the French system of market gardening was about $£ 500$ per acre-this at pre-war prices ; in fact all these figures are pre-war, as with the present rapid fluctuation it is hard to give reliable figures.

From the 5-acre market garden and fruit holding I have three returns showing $\oint_{1} 10, £_{12} 5$ and $£_{1} 30$, as the net cash income three holders received from their land; and this after paying annual instalments which would purchase the land in twenty years. To these cash receipts should be added the value of the produce from the holding consumed by the family.

Taking the fruit farm of 30 acres, for instance, in the Evesham district, at a conservative estimate the gross yield per acre would average something about $£ 60$, and the net profit about $£_{2} 20$ per acre. The Lancashire grassland holdings show about as good results as can be found from this type. I have seen well-kept accounts in this district which show profits ranging from $£_{8} 8$ to $£$ ro per acre, and a gross turnover of up to $£ 3^{\circ}$ per acre. I have been on holdings of 30 acres which were carrying fifteen cows and a number of pigs - this is what may be termed "intensive grass farming." But these holdings were splendidly situated in regard to markets, and the men themselves were particularly progressive. The average grass-land holding of 30 to 50 acres probably does not yield more than a cash profit of $£^{2}$ per acre. And very 
much the same result is obtained from the average small mixed farm, except where the land is particularly good as, for instance, in the neighbourhood of Spalding. Here the area that provides a man with a good living is much less than in most parts; men can do well on 20 acres.

A notable feature on the Continent is the way in which the smallholder builds up his land, turning, by his treatment of it, light poorish soils into highly productive. We have hardly begun to understand this, and in consequence the general opinion is that it is essential to place smallholders on land of very good quality. Heavy land is not suitable for small holdings; but comparatively poor land, provided it is easy working, is suitable and, as it can be bought at a lower figure, an important saving in the initial expenditure can be effected.

I know intimately a holding of 27 acres, on land that would fetch from $£ 20$ to $£ 25$ per acre in the market, which has been handled in an up-to-date way. It is an arable dairy farm, carrying ten cows in milk; the only grass, a paddock of I acre adjoining the cow-shed; cropping 5 acres lucerne, 7 acres mangolds, I4 acres oats and barley. The financial results of an average year (1914) were-gross sales of milk, oats and barley $£_{53}$, or just under $£_{20}$ per acre. The profit received by the smallholder was $£_{220}$ or about $£^{8} 3$ s. per acre; this after paying all working expenses, rent, rates and his own wage at $£ .5^{\circ}$ per annum, but not including interest upon his working capital which was $£ 35^{\circ}$ or about $£_{13}$ per acre. At the present time it would require more than twice as much working capital to ensure success. But his gross receipts last year were about £1000, and his profit $f_{400}$

'The buildings, standings for ten cows, two pigsties 
and an implement shed, cheaply constructed in wood, cost firo. The good three-bedroomed and parlour cottage cost $f_{225}$; fencing and water (laid on from a main close by) $£_{25}$-total $f_{3} 30$. This equipment could not be provided to-day for less than $f_{2} 2000$.

This holding is an interesting example of the application of Danish methods to a small holding in the eastern counties; and the gross yield, with profit per acre, is largely in excess of that obtained from the usual small holding on similar land in this country. But it shows what can be done. After four or five most profitable years the Danish tenant returned to Denmark; the present holder is an Englishman who has been in possession for two years, and is doing as well as his predecessor.

Expensive machinery ought to be owned co-operatively and serve a group of holdings ; only so can its economic use be secured. Much nonsense is talked about all the holders wanting the machine at the same moment. In practice, where this system is properly worked, the results are satisfactory; and it means that the small farm can thus be placed on a par with the large farm in regard to up-to-date machinery. It would be unwise to forecast the profits derivable from farming during the coming years. But this can safely be said that, as far as labour is concerned, the smallholder will be in the best position because he is independent of outside labour.

\section{THE MEDIUM-SIZED FARM}

So much for the economy of the small holding; we will now consider that of the medium-sized farmsthose of 100 to 300 acres in the eastern half of England. One finds that many of these are under-capitalized and, 
quite apart from that point, are in the hands of men who are not farming them well; some of these men are incapable of better farming, others would improve greatly under guidance. But in any such question as this, the great variations as between counties must be remembered. In the North Riding of Yorkshire, for instance, the 250-acre farm is generally very well done, and the falling off is in the 400- to 600-acre farm; whereas in Lincolnshire the 400- to 600-acre farm is generally well done, and the $200-$ to 300 -acre farm may be indifferent.

One important result of the War Executives has been to bring home to the agriculturists who worked upon them how serious is the degree of bad farming in this country. It is only when information is tabulated that one can really see how matters stand. Every day good agriculturists, in their walks abroad, used to see the bad farming of the medium-sized farms; but they were not in the limelight as were our small holdings, and so little notice was taken of the condition of these farms.

It is quite certain that a large number of the indifferent medium-sized farms did not bring in 10/- per acre profit to the tenant. The working capital before the war could not have averaged over $f_{0}^{6}$ per acre and often much less. Farms of this description were let at from $10 /-$ to $12 /-$ per acre. On this basis the farmer who put in, say, $f_{1} 1800$ as working capital on a 300 -acre farm, and cleared $£ 150$ per annum, after paying rent and working expenses would only have $£ .78$ for his personal remuneration after paying 4 per cent interest on his capital. It is true he had his house rent-free, and the greater part of his household requirements from the farm; but still the results are ridiculously inadequate, when one 


\section{THE LAND AND I'TS PROBLEMS}

considers the intrinsic capital value of the land and its potential income-earning capacity.

It cannot be said that this class of farmer has very materially improved his position during the war. The large and good farmer has done so. He was able to make the best (and quite legitimate) use of the opportunity to win back, for the agricultural industry, some proportion of the capital lost to it during the great depression owing to the lack of intelligence on the part of the Government and the nation. Looking to the future I think we shall see this type of farm absorbed into large industrial farms, which are bound to develop, or where the land is suitable turned into small holdings.

Coming to the good farmer, I personally know men who always counted on doubling, or even trebling, the turnover of any farm they took over from an indifferent farmer; and they generally succeeded in doing so. Here mixed arable farming is under review ; not potato farming in which the gross turnover is very high. The men referred to secured a gross turnover of from $£_{10}$ to $£ \mathrm{I} 2$ per acre, and a net profit of from $£^{2}$ to $£ 3$ per acre, as compared with the average $£ 4$ per acre gross output and $£_{\mathrm{I}}$ per acre profit. Where the term net profit is used, the profit after all working expenses, and rental, and interest on the capital has been paid, is meant. Otherwise, where the term profit is employed it means the cash available for the farmer to spend, after having paid rental and working expenses but not interest on his working capital.

A 1912 budget of a 1000-acre mixed farm in Germany, where the gross turnover averaged $£_{1} 6$ per acre, shows a net profit of $£ 4$ per acre (the value of the products having been worked out at the then current English prices). 


\section{THE INDUSTRIAL FARM}

Much has been heard of the advantages to be gained from the really large industrial farm of 5000 acres, or even up to 10,000 ; there is certainly room for this type of farm; in fact it could play a very important part, particularly in improving the cultivation of poor, heavy land.

I am in no way opposed to this development, but there are many difficulties in the way of achieving it ; difficulties which I have experienced personally, for I have been connected with such an enterprise.

First, a very large amount of capital is necessary$£ 100,000$ working capital for a 5000 -acre farm is about the lowest figure at which it can be put, and at least another $\oint_{100,000}$ if the land is bought and not rented; and it is by no means easy to get capital for agricultural enterprise in England, though if the venture were in Patagonia it would probably prove attractive!

Secondly, it is by no means easy to find the right manager, and success or failure will depend upon the manager.

Thirdly, a large labour staff will be necessary; and at present, and probably for some time to come, the handling of large groups of labourers presents special difficulties.

Fourthly, even if well paid, the relations of the labourer to the employing company, or syndicate, are not as healthy as those which exist where there is a resident farmer. And, from the social point of view, the labourer would be more valuable to the community as a smallholder than as at member of a large staff.

Fifthly, the overhead charges are high, especially if the directors have to be paid; these charges might well 
swallow up all the profits if the management be at all defective.

If the industrial farm is to be of full benefit to the nation, it is clear that it should absorb the indifferent medium-sized farms on land not suitable for small holdings. Public opinion would be averse to industrial farms absorbing typical smallholding land. The advantages are that it is potentially easier to run a very large farm as a business, and secure the economic use of costly machinery and the full organization of labour. For purposes of management it would probably be found advisable to divide the large farms into " management units " of 1000 acres ; even so, it would be hard to find really efficient managers of I000 acres, and harder still to find a man fully qualified to be the super-manager of 5000 acres. This country does not produce many such.

People who have but a superficial knowledge of agriculture are often heard to argue that, because the big factory is more economic than the small factory, the big farm must be more economic than the small farm. But this argument can be pushed too far even in the case of the factory; the small factory has certain advantages from the human point of view, and its " economy" could be greatly bettered by a full development of electric power.

When one comes to the land the comparison to a large extent breaks down; agriculture is fundamentally different from any urban industry. Not only is it more affected by the weather, but the human element comes into it on a larger scale than into any other industry. The handling of animals forms a large part of the work -and the "pony fattens best under the master's eye." The land itself responds to the individual in a way and to a degree that a machine does not. It is impossible to 
give the same degree of individual care per acre on a 1000-acre farm as can be given on a 30 - to 50 -acre holding.

And again, among the men working on large farms there are, and always will be, a certain number whose ambition it is to have individual holdings of their own; this is a healthy ambition which should be satisfied. The importance of the sinallholder in stabilizing the social condition must not be lost sight of; and as soon as circumstances permit the development of small holdings should be taken in hand again. Meanwhile, those desirous of a small holding, and not averse to migration, should be given the opportunity of settling in our lands oversea on the best possible terns and under carefully organized conditions.

To sum up from the figures I have given in this chapter, it is clear that even under the present unfavourable conditions the average production per acre from the small holding is higher than the general average for the country, and the same holds good in regard to profit.

The following table is interesting as showing the results of a well-run colony-which is indeed a settlement-in regard to the head of population and live stock carried, marking the increase in favour of small holdings.

\section{Cheshire County Council, 1916.}

Four Colonies afsregating 3070 acres.

\begin{tabular}{|c|c|c|c|c|c|c|c|}
\hline No. of Holdings. & & $\begin{array}{l}\text { Popula- } \\
\text { tion. }\end{array}$ & Cattie. & Horses. & Pigs. & Sheep. & Poultry. \\
\hline Is at present & 95 & 536 & 2282 & 170 & 1256 & 210 & 3400 \\
\hline Before purchase. & 29 & 175 & 11.42 & 6,3 & $3 n 6$ & 100 & 760 \\
\hline Increase . & 6r, & $3 \sqrt{1}$ & 11.10 & $1(1) 7$ & 050 & 20 & 2640 \\
\hline
\end{tabular}




\section{FARM ACCOUNTS AND DEMONSTRA'TION} FARMS

T $\mathrm{N}$ a preceding chapter sufficient evidence has been produced to show that arable land produces more food per acre than grass land; and all the evidence also goes to show that our land, both arable and grass, should produce more than it does. But we need information and data which can come only from carefully kept accounts; we must know the financial results of the application of new scientific methods to the land on a commercial scale.

All increase in production is due to the application of science to the land. In the thirteenth century the yield of wheat in England was only about 5 bushels to the acre; this yield has been gradually increased until it now stands at an average of $3 \mathrm{I}$ bushels per acre.

The first improvements were due to the learning by practical farmers of how better to perform the processes of cultivation. Then there is the science of the seedsman, who studies varieties of seeds, and makes improvement by selection and the actual breeding of new varieties; and finally there is the science of the highly trained man who tells the agriculturist what chemicals to use. We have by no means yet reached the limits of what science can do for agriculture. For this reason exact data are needed to show the results, on a commercial scale, of 
the application of certain methods and of certain scientific discoveries to the land. "This should be the great work of the Agricultural Costings Committee already referred to.

It is quite impossible to make guesses in regard to the law of diminishing returns. This economic law has an important bearing upon agriculture, for there is a point in production beyond which it does not pay to go ; but it is not an immutably fixed point. Let us take a concrete example : supposing the yield of wheat to be 30 bushels per acre-at which it gives a profit of, say, f. 3 per acre -in the interests of agricultural development we should like to increase that yield to 40 bushels per acre. If the money spent in higher cultivation, to secure the increase of ro bushels, is more than covered by the value of the increase then clearly it is good business. But if the cost of producing those ro bushels exceeds their value, then from the farmer's point of view it is bad business.

If it were our object to produce an increase of 20 bushels instead of 10 bushels, although we could do it, we should find that the profit (if any) would be less on the second 10 bushels than on the first. Or, looking at it from a somewhat different point of view-if the application of $20 /$ - worth of artificial manure per acre leads to an increased yield in grain to the value of $30 /$ per acre, it is a paying expenditure ; but to spend $50 /-$ upon artificials and obtain an increase of, say, 40/worth of grain would be uneconomic.

Only by the proper and scientific book-keeping of "demonstration production," can we find out at what point the law of diminishing return becomes active.

It is noticeable that, while in this country we stand much in fear of this law, on the Continent 
farmers are much more interested in the converse law, that of "increasing return." That is why, as already stated, the average yield of wheat in Denmark is some 30 per cent higher than it is here.

The great difficulty is that, not only do farmers not keep sufficiently accurate accounts, but they are naturally averse, even under the seal of secrecy, to disclose the real results. ${ }^{1}$ Therefore, it will only be by means of establishing a large number of demonstration farms, run by the State (or local authority on lines laid down by the central authority), that we can hope to get the accurate information needed. The twofold object must be kept in view :-

(a) Of increasing the yield per acre;

(b) Of reducing the cost of production per acre.

Now one of the chief features in cheapening the cost of production is the organizing and efficient handling of labour. And here comes in the personal equation; one man is a born organizer, and the next is not-in fact, for one man who can organize his labour well there are probably ten who cannot do so. But these ten, under a proper system of expert guidance, can be induced to employ the best methods in regard to the general treatment of their land. The expert, however, cannot be fully effective unless he has a farm for practical demonstration.

The interim report of the Costings Committee deals with the accounts of some 300 farms, covering 146,000 acres in England, Wales and Scotland, and shows a profit of $f_{\mathrm{I}} 6 \mathrm{~s}$. per acre or Io per cent on the farmer's working capital. This ro per cent interest is really gross interest, for nothing is allowed to the farmer as

1 The compulsory returns for Income Tax under Schedule D, will soon produce valuable results. 
remuneration for his personal services. A definite deduction should be made for this.

Again, taking the profit in terms per acre, $f_{\mathrm{I}} 6 \mathrm{~s}$. is clearly an impossible figure; much too low. If reference is made to Mr. Strutt's statement (page Io8) one can be well assured that, if his profit was over $£^{2}$ per acre in 1912, the profits in 1918-I9 must exceed $f_{\mathrm{I}}$ 6s. per acre; and the writer knows one farm intimately, on poor land but under particularly able management, where the net receipts per acre were over $\ell_{5}$ during the whole period of the war. Further, this profit of $f_{1}$ 6s. per acre does not represent excess of receipts over expenditure, but is entirely earned by increase in valuation: i.c. the stock, etc., on the farm was worth more at the end of the year than at the beginning. And if really valuable accounts are to be kept, one of the first principles to recognize is that the valuation and variation in stock, etc., should come under the head of "capital account," and not "current account."

The net profit on a farm should be the excess of receipts over all expenditure during the "farm year."

Increase in stock which could have been sold, but was not sold, should not come in ; that increase comes into the "capital account," and may or may not be realized during a subsequent year.

In my own farm accounts the stock is still returned at pre-war values; all I want to know is whether the original working capital, that I put into my farm, is covered by the stock, etc., at present on the farmvalued by a professional valuer and at original prices.

If I wind up my business, and retire with an increased capital, that increase should be shown as capital, and not as an annual profit.

I am sure that Sir A. D. Hall is right in keeping to a 
fixed valuation, of so much per acre, in his farm accounts. It is an important point ; for it is misleading to show in the net profit for the year sums which are not realized, and often cannot be realized. The net profit should be the sum that can be actually withdrawn, and used as income, by the farmer.

To give an example, in illustration, not of a farmer, but of a man with $£ 20,000$ in securities at 5 per cent.

To Value of Securi-

ties at beginning

of year

Profit .

$$
\text { - } £^{20,000}
$$

$$
\frac{\mathrm{I}, 400}{f^{2} \mathrm{I}, 400}
$$

By Value of Se-

curities at end

of year.

By Interest at 5

$£^{20}, 400$

per cent

$$
\cdot \frac{1,000}{£ 21,400}
$$

But the man's income is not $f_{1400}$, but $f_{1000}$; and if he based his annual expenditure on the basis of such a balance-sheet, he would soon find himself in financial difficulties. There is no doubt that a considerable number of persons connected with agriculture have become financially involved, because they have failed to distinguish clearly between capital and income.

Another point in farm accounts; it is interesting to see the total results of the operations of the farming year, and not to carry profit belonging to one year on into the next, or at least to as small an extent as possible. If on April 6th, 1920, for instance, you have on hand corn estimated at $£ 400$ from the I9I9 crop, I like to see that shown in the profit for the year 1919-20 and not carried on into the next ; for probably that corn will be sold within a few weeks of closing the accounts and a subsequent adjustment can be made.

So that the form of balance-sheet which I have adopted 
is as follows. It is taken from a balance-sheet worked out by the chartered accountant and is only another and, to my mind, clearer way of saying the same thing. And if partnership farming between the landowner and his manager should develop in this country, I am sure it is the best form to adopt.

\section{FARM}

April 6, 1917 , to April 6, 1918

CURRENT ACCOUNT

Dr.

$$
\text { f. s. } d \text {. }
$$

To Corn and cake purchased. Seeds $: \quad 103$ I 9

Implements : $\quad 53$ II

Miscellancous expenses 483 o 3

Wages $111510 \%$

"Rates, taxes and losur.

ance . . 971911

, Rent : 433 I6 o

"Interest on working capital : 25092

- Cattle purcbased . 129 17 0

". Horses . : 12930

". Artificlal manures $\frac{368 \text { I5 }}{£_{410549}}$

„Profit for division with partner

$$
\begin{array}{rr}
2666 \quad 15 & 1 \\
86771 \quad 1910 \\
\hline
\end{array}
$$

By Corn sales. . . 3117 s. $d$.

Milk sales. 2565 I1

"Hay and straw sales : $\begin{array}{r}23 \\ 2329\end{array}$

"Cattle sales . 974 I 9

". Misccllancous receipts 9103

Nole. The sale of cows this year was somewhat above the average.

On April Gth there was no corn "On hand" this

year.

To Valuation April 6, 1917 "Increase being profit (not withdrawn)

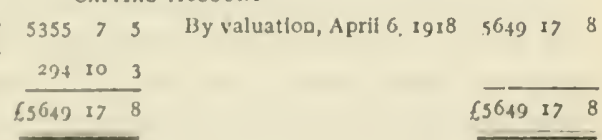

Gross sales of produce per

acre
Average yield of milk per cow, gallons

Average yicld of wheat per acre, qrs.

Total $\longdiv { 6 6 7 7 1 9 1 0 }$

Average yjeld of baricy per acre, qrs.

Average yield of oats per acre, qrs.

Cost of labour per acre.

$\begin{array}{llll}\text { Cost of labour per acre } & \{2 & 3 & 0 \\ \text { Cost of artificials per acre } & 60 & 4 & 0\end{array}$

$\left\{\begin{array}{llll}13 & 0 & 0\end{array}\right.$

657

41

51

8

\section{Capital account}

Note.-A licensed valuer values each year, and at prewar prices. The one object befng to see that the working capital dres not drop below the 6,5000 originally put in. 


\section{8}

\section{THE LAND AND ITS PROBLEMS}

At the present time, with the existing attitude of the consumer towards the producer, there is no doubt that, even if their system of book-keeping would enable them to do so, few good farmers wish to disclose the results they achieve.

With the prices for agricultural commodities that have ruled since 19I4 the good farmer has made a good profit; but the indifferent farmer has been faced with difficulties, and increased expenditure, that leave him only moderately better off than he was in pre-war days.

The net income, per acre, of the average farmer on medium-sized farms was very small indeed before the war, 20/- an acre and often much less. The good farmer, who was a good business man as well, made much more; but then he was producing more food for the country.

This is a point the consumer should remember; also that the good farmer has a right to deduct a substantial salary for his own work, before he declares his rate of interest. It is for this reason that I feel that not only should careful farm accounts be kept, but that they should be made public without reservation.

With the increasing cost of labour it is essential to have first-class book-keeping; so that the rate of labour per acre, in producing various crops, can easily be ascertained. At no period in our agricultural history has it been more important to reduce the cost of production; and this cannot be done unless we can accumulate the necessary data, based on accurate accounts. They are the searchlights which illuminate the road to future developments. 


\section{THE DEMONSTRATION FARM}

A demonstration farm must be a success commercially or it will not serve its object. It differs entirely from an "experimental farm"; which is not supposed to payit is really a " rescarch farm."

We are behind other countries in regard to demonstration farms; only quite recently can we be said to have had any at all, and the worst of it is that those we now have are losing heavily. This is no good at all, but the demonstration farm in continental countries pays, and pays well, and it must be made to pay here.

The demonstration farm is essential to our future developments ; without it we shall never get an accurate system of costing.

And one reason why our new demonstration farms do not pay is because in England we can rarely find the right type of manager to handle them. A highly qualified man is needed, and though of course we have many highly qualified agriculturists in England, they will not accept the post of manager of a Government farm for a salary of $£, 500$ or $£ 600$ a year; they can do far better than that on their own. A first-class manager should earn an income of from $\oint_{1} 1000$ to $\oint_{1500}$ a year, and the bulk of it should be derived from a percentage on the profits he has earned for the farm-payment by result is the soundest of all business principles - but unfortunately it is a principle which is not understood by the Imperial Treasury ; if it were, we should have a very different showing for the expenditure of public money!

Then again our existing demonstration farms are not real demonstrations on a commercial basis. They are mixed up with settlement scliemes; ex-service men 
are sent to these farms, often men not carefully selected, and who are not good workers. Or else the Ministry of Agriculture interferes with the manager of the farm, and prescribes the method of farming ; in certain cases a different method has been prescribed every six months. All this is quite impossible. Once a good manager is appointed he should have absolute control; he should choose his labourers, and devise his own scheme of farming.

This principle is as fundamental as it should be obvious; yet it has been entirely ignored by the Ministry of Agriculture.

The result, - a complete failure of the State farms, and the admission on the part of the Ministry, after two years' bitter experience, "that farming cannot be conveniently managed from Whitehall "! 1 The admission is valuable, but the experiment has been costly, and the loss could have been avoided had the Ministry really studied how Demonstration farms are managed in countries in which they have been a great success.

1 Vide the debates in Parliament on the Ministry of Agriculture vote, April I9, I92 I. 


\section{CHAPTER VIII}

\section{ON TAKING UP AN AGRICULTURAL CAREER}

7 HIS chapter is meant for the man who wishes to live in the country and to take up farming, but who

1 has had no previous experience of agriculture.

There is no doubt that at present a large number of men would like to farm if they thought there was a fair prospect of success. Some of these men have capital, and could embark upon farming on a fairly large scalelarge farming as opposed to small farming.

Many of them, on the other hand, would not have much capital; sometimes, not even enough to run a small holding properly without recourse to borrowed capital.

THE INEXPERIENCED MAN WITH CAPITAL

Take first the case of the man with a fair amount of capital. He is inexperienced, and he may elect to go through a course of study which will give him a certain insight into farming operations ; this would be all to the good, but it would not give hin the practical knowledge or experience requisite for the successful running of a large farm.

He might, of course, either buy or rent his $400-$ or $500-$ acre farm, put in an ordinary bailiff, and following the usual methods of the gentleman farmer have a pleasant 
life and home, and not lose much. But this would not be doing his duty by the land; he should set out to earn a really good interest on his capital, and also be determined that the land for which he is responsible shall produce the utmost for the nation.

If he elects this-the better part-then he should go into partnership with a first-class man of practical experience and up-to-date knowledge, vide the description of partnership farming (Appendix No.V); American business men largely resort to this practice in the States of New York and New Jersey.

At present it is still difficult to find the right type of partner in this country, though not impossible. If such a man cannot be obtained we can draw upon Denmark; but the ultimate object should be to train Englishmen for this work, and there should be an everincreasing demand for such services.

Under the terms of partnership which I advocate, the active partner, if he is capable, earns good remuneration; and at the end of ten years or so he is very often in a financial position to start on his own. So that the passive partner should see that he has an understudy to the active partner coming on ; or if he has the ability, and has worked closely with his partner, he should be ready to take on the management of the farm himself. During the term of partnership, presupposing a wise selection, the active partner should not be interfered with in any way; and the farm should not be expected to do casual work for the house or garden, or to provide the household with any commodities.

To be successful it must be a business concern. Everything that is grown on the farm must be sold in the best market, and the farm staff must work for the farm alone. If the house buys milk or eggs from the 
farm, it must pay cash for them. And if the passive partner wants extra work done in the pleasure grounds or kitchen garden, he should get in an extra labourer, so as not to upset the organization of labour on the farm.

\section{C.APITAL REQUIRED}

For this partnership farming, in general terms, it would be a mistake to make the unit less than four or five hundred acres of good average land. The profit from a smaller area would not be sufficient to attract a really good working partner. The farm could be rented or purchased according to the amount of capital available ; the point to bear in mind being that, whereas $f_{10}$ per acre was a fair working capital before the war, now it should be at least $£ 20$ per acre, for stocking the farm, etc., so that a total sum of $f_{10,000}$ would be required for a 500 -acre farm. ${ }^{1}$

Suitable land can be bought in most counties at from $£ 25$ to $£ 35$ per acre; but it is gencrally cheaper, so long as the present low rents continue, to rent rather than to buy the farm-though there is always the risk of the owner being obliged to sell, and the tenant being turned out in consequence.

Where possible, it would be desirable to consult the active partner before taking the farm-in any case he should be consulted in regard to the outlay of the working capital; he has to pay the passive partner interest on this capital, so it is only fair that he should have the right to see that it is expended in the most effective way possible.

It must always be remembered that the first two or

I With the downward tendency in prices the amount of working capital can be reduced. 


\section{THE LAND AND ITS PROBLEMS}

three years of such an enterprise are lean years; particularly so if the farm taken is not in good condition, when the first task is to get it into order. In my own case the farm was in a very bad state; yet my partner paid me, from the outset, full rental and 5 per cent on my capital-this before the war! After the second year, profits were earned which were divided up. See Appendix V for copy of the very simple form of partnership agreement.

Next, as to the class of farming recommended. The arable dairy farm has strong recommendations; the main sales therefrom-milk, corn and pigs - the products most needed by the nation are at the same time most profitable to the farmer. There would, of course, be variations in each individual case, and on some farms a fair area might be devoted to potatoes.

Grass farming need not be excluded from the partnership system, but, if it be chosen, the grass should be thoroughly well handled, and the highest possible head of stock carried; what arable there is should be made full use of, and if the farm is on the western side of England the Harper Adams method of green cropping might be adopted.

The area of the partnership farm might, of course, be much more than 500 acres; but it is always wise to avoid embarking on too large a scale, and there is the danger of a keen and active partner taking on more than he can manage effectively, which should be carefully avoided.

\section{PROFITS}

As to the profits that can be earned, it is impossible to say what the future has in store for the agricultural industry ; its future, as that of every other industry, lies 
in the lap of the gods. Supposing conditions to be normal, at a conservative figure a well-run farm on average land, producing milk, corn and pigs, should yield up to $£+$ per acre net profit, after paying rental and all other expenses (including 5 or 6 per cent on the working capital). This profit would be shared equally between the partners; so that the man embarking on a 500 -acre farm would, on this basis, get fiooo a year as his share, which would bring the total interest earned by his $f_{10,000}$ working capital to the very respectable rate of $\mathrm{I}_{5}$ per cent. But the consumer must not say that this is profiteering, for there are bad years in farming as in every other industry; and the farmer, if he be well advised, will put by each good year a certain amount to a reserve fund.

\section{TIIE MIAN WITII SMALL CAPITAL}

Coming now to the case of the man with little capital, say under $£_{0} 1000$; unless he is really capable of hard manual work on the land he should not think of farming. 'The first step would be for him to test himself thoroughly by going on to some farm for a period of three months and working as a labourer, for success will depend upon his own power of work ; and if he is on his trial in summer time, and likes it, he must ever bear in mind that work in the winter months is a very different matter. There is not the faintest use for the would-be farmer of this type to think that he can do some of the work limself, and employ permanent outside labour for the resthis small holding cannot stand it. It is the individual work of the smallholder himself that counts more than all else. 
For a young man, say, I6 or 17 years of age whose parents can afford to send him through a proper course of training, the ideal procedure is the Agricultural College and work on a farm under a good farmer. But it must not be thought that one or two years will be sufficient; it is a question of steady training for four or five years. So that it is very essential to make certain that the youth, quite apart from his mental capacity, has a real aptitude for manual work on the land; and he should undergo the test already referred to.

During the period of training, a good plan is for the pupil to spend one or two holidays on a farm in Denmark, working as a labourer.

These months on a Danish farm would give the student a new point of view; and he would be working in a country where the development and organization of agriculture have been carried to the highest level yet achieved. He would see around him small arable dairy farms and how they are worked by men who know their job. I am here assuming that the trainee intends to make his living by actually working on the land; should he wish to go in for a position under the Ministry of Agriculture or a County Council this will still be the best training.

In Denmark the usual proceeding is for the pupil, who intends to become a farm manager or expert, at the end of his course of training to go on to a large farm and work as under-bailiff for two or three years at a salary, under a manager. In this way he acquires business experience, and it is most necessary for him to learn how to buy and sell to best advantage. This side is not of so great importance where a man settles under the group system, or where co-operative buying and selling is developed. 
At 2 I or 22 year's of age most men are too young and inexperienced to start on their own, or to be entrusted with the management of a large farm.

Although there are an increasing number of positions under public authority for the highly qualified expert, there is danger of the supply excecding the demand; and the salaries for these posts only average about $f_{5} 00$ a year under County Councils, and up to about $f_{1000}$ a year under the Ministry of Agriculture.

If, however, the system of partnership farming develops considerably during the coming decade, there will be increasing opportunity for the type of man I am dealing with here; and if the man is really highly qualified he should be, as manager-partner of a farm, in a position to save enough capital to enable him to take a fair-sized farm of his own before he is too old.

It is clear, however, that older men, perhaps exService men who do not wish to return to a sedentary indoor occupation, cannot give up four or five years to training.

What are they to do?

In regard to training, the first step must be the test as a labourer on a farm; if this is passed successfully, then a short course (not exceeding a year) at an agricultural college should follow.

'The pupil must learn how to plough and how to handle the ordinary implements and effect simple repairs thereto. He nust learn how to milk and how to feed live stock, how to keep simple accounts, and as much of the theory of agriculture as he can acquire in the time.

Those who elect to settle overseas can still make the test at home; but the oversea authorities quite rightly insist upon a year's training on the spot before the settler is actually granted a holding. 
Where training takes place upon a large farm, even under a first-class farmer, this is rarely the best preparation for the management of a small holding-the methods are so different.

Having received his modicum of training, it is absolutely essential that the would-be smallholder should settle in a group or colony of smallholders; there he will derive the benefit of co-operation with his fellows, and there he can continue his training under an expert.

For some years he will require guidance in handling his farm ; in fact, effective guidance is his one guarantee of success. And, next to guidance, access to capital ; even if a man has sufficient capital to start a holding, he should only settle where he can be certain of borrowing further capital on advantageous terms, should this be necessary for the development of his holding. This comment applies, with still greater force, to the man who has not sufficient capital to equip his holding and who has therefore to borrow at the outset.

The following paragraphs describe the different courses open to a man with little capital, who wishes to become a farmer. It is clear that to begin with he must be content with a small area of land, whether he remains at home or migrates. In the United Kingdom a small holding is technically a farm of 50 acres or under.

(I) The would-be smallholder could rent an oldestablished holding on a private estate. He would have to apply for it just like any other small farmer; he would have to satisfy the owner, or his agent, that he had sufficient capital and knowledge to farm the holding properly-and here he would, in most cases, find considerable difficulty. For a small mixed farm, 30 acres 
is about the smallest economic area and, putting the working capital at $£_{2} 20$ per acre, a minimum total of $£ 600$ would be required.

In the "Settlement Facilities Act" power is given to the County Council to advance one-half of the total working capital required; but the man who settled upon a private estate could not claim this advance. Further, he would probably be on an isolated holding; or, at all events, if there were other small holdings thiey would be in the hands of old experienced agriculturists, mostly men born to the profession. Nost County Councils now have a good instructor in agriculture, and another in horticulture, and often several specialists as well; as a ratepayer the new smallholder has a right to their services and he should have recourse to their assistance in the cropping and cultivation of his holding ; he can secure this assistance by writing to the County Agent or Organizer.

In practice, I fear very few men would be able to get small farms on private estates; but, in spite of the difficulties I have mentioned, a good sniall holding on a private estate is let at a lower rental than one obtainable in any other way.

(2) To take a holding under a public authority; the County Councils are the main small holding authority, although the Ministry of Agriculture has a certain number of group settlements where some attempt is being made at organized settlement. ${ }^{1}$ I have already criticized the methods adopted by the County Councils, and "organized settlement" is further dealt with in Appendix IV.

However these considerations are really beside the point, for although by Act of Parliament the County

I It is now proposed to hand these over to the County Cuuncils. 


\section{THE LAND AND ITS PROBLEMS}

Councils are supposed to provide land for applicants living within their jurisdiction, they are not obliged to do so for men wishing to migrate from the town.

The basic fact is that, owing to the cost of building, it requires an absolutely prohibitive sum to equip a new small holding. And owing to straitened public finance, it is practically impossible to get from the County Council the loan of one half the necessary working capital.

We must therefore face the fact that, for the present, it is almost impossible for an inexperienced man to obtain a small holding in England; also that, from the national point of view, the experienced agriculturist should be considered to have the first claim. We must enable as large a proportion as possible of our agricultural labourers to get small holdings, or at all events allotments, and so finally to work up to the full-fledged small holding. As it is, the national exchequer is bound to lose many millions sterling on the small holdings which are being provided for those ex-Service men who were agriculturists before the war, and who are now applicants for small holdings.

(3) On previous pages I have urged the necessity of increasing the number of cultivators, by recruiting them from the ranks of those with little or no previous experience in agriculture.

Yet in the preceding paragraphs I have been pointing out how impossible it is for them to get upon the land at home. And this is a situation which we must accept for the present, until such time as the cost of building and equipment comes down and until we have a number of full-fledged group settlements in this country.

So it comes to this ; the man who is really determined to go in for farming, who has the necessary strength and 
aptitude, must go to the parts of the Empire where there is suitable land, where the cost of equipment is low and where the Government make generous arrangements for the advance of necessary working capital to the settler.

At home the cost of house, farm buildings, etc., necessary for a $30-50$-acre holding is, at present, about f.3000; in Australia or New Zealand, for instance, a nice cottage can still be built for about $£ 300$, and owing to the climate little is required in the way of buildings.

Practically all the Dominion Governments are far more generous than the Home Government in regard to loans to smallholders; but here again the money shortage is making itself felt, and the Oversea Governments are having to restrict their operations.

The type of man I am discussing now is just the one so much needed in our Dominions; and he will be doing a great Imperial service by helping to people and to make productive the unoccupied lands of the Empire. ${ }^{1}$

\section{THE POULTRY FARM}

There are so many men who fancy that they would like to run a small poultry farm and, worse still, so many who have tried it and failed, that I must put in a word of warning.

The high prices for poultry and eggs which ruled during the war gave a great fillip to poultry farming, and undoubtedly many people have done well in this branch of "live stock."

But the fact remains that, with normal prices, very few men can succeed in making a living out of a poultry farm.

1 Jor information in regard to settlement in the Dominions, application should be made to the Oversea Settlement Committee, 6, St. James Siquare, S.W. I. 
This seems to be the case in the Dominions as well as at home; poultry are a most important adjunct to the small farm (and to the large farm, too), but as a mainstay they should be avoided.

Though I have recounted in this chapter the difficulties of getting a small holding in the United Kingdom, it is still quite worth the while of any man, who does not wish to emigrate, to try his luck and apply to public authority on the chance. The different types of small holdings have already been described in Chapter VI. 


\section{CHAPTER IX}

\section{THE OBJECTIVE IN PRODUCTION AND FUTURE DEVELOPNIENTS}

I

T is hard to say what the future has in store, but one thing is quite clear-and that is, that radical alterations will have to be made in our land system and in our methods of cropping. ${ }^{1}$

If landowners and tenant farmers are wise in their generation they will not only recognize this, but will take an active part in initiating the essential alterations.

If the present owners and occupiers are reactionary, and oppose all change, there is danger that the mass of our countrymen will condemn the present land system as so hopeless that it cannot be mended, and they will lend a ready ear to suggestions for nationalization; although it should be self-evident that nationalization in itself cannot alter the character or capacity of our cultivators. Or if the idea finally takes hold that the agricultural labourer should succeed the farmer as the manager of land, working in some way under the State instead of under the individual owner, surely it should be apparent to anyone who gives the question a moment's thought that, for such a system to be successful, the labourer must be educated and trained to become an efficient manager of land?

1 See Appendix No. VI which gives the report of a short specch made by Lord Sclborne when he took the Chair at my lecture to the I.ondun School of Economics, March $10,1916$. 


\section{THE LAND AND ITS PROBLEMS}

So we come to the root of the matter : education and training.

There is any amount of latent capacity amongst our agricultural labourers, but it must be developed by training. Because a man is a skilled labourer it does not follow that he would be a good farm manager. Many labourers have risen to the position of farm bailiffs in this country; but if their qualifications, and the results they achieve are compared with those of the Danish farm manager, the amount of leeway we have to make good at once becomes apparent. But then the Danish farm manager, in the first place, is a well-educated man ; and, secondly, he undergoes years of training before he is entrusted with the management of a farm.

Even supposing the system of labour-managers under the State is developed-and this may be described as the nationalization of the agricultural industry, as distinct from the nationalization of the land-all labourers, even if qualified, could not be managers. And from the point of view of labour, will the labourer-manager be any better than the tenant-farmer-manager of to-day? It is notorious that the labourer, who rises to the position of manager in any industry, is often the hardest task-master of all. I am not here defending the tenant farmers; a large proportion are bad farm-managers, chiefly because of defective education and training. So again we come back to education.

Putting aside the question of nationalizing the land or the industry, ${ }^{1}$ too large a question to go into here and unprofitable for it would only be discussing wild experiment based on no concrete precedent-let us sum up certain points in regard to the tenure of land.

(I) The great estates are in process of breaking up, 1 See Appendix No. VII. 
and the land to-day is owned by a far greater number of persons than in I9I4; to this extent the old system of landlord and tenant has been modified. It is safe to predict that this process will continue. In fact the provisions of the Agriculture Act in regard to compensation will increase the desire of many landowners to sell, although it may lead owners to wait until a farm is vacant before they put it up for sale.

On the other hand the high rate of interest now charged by banks for advances of capital, and the lack of land banks, may check for the moment the amount of land thrown on the market; certainly it will make it more difficult for the sitting tenant to buy his farm when it is put up for sale.

(2) Landowners will be forced to farm, on a strictly commercial basis, a larger amount of land than has been the practice within recent years; in fact ere long the landowner may be found farming all the land which he has not sold-as is the case in most of the continental countries.

(3) And if the landowner is to farm successfully, there is no doubt that he should more and more adopt the partnership system of farming; and measures to train the future farm managers should be taken.

(4) 'There could be, with advantage, a considerable development of commercial farming by companies constituted for this purpose ; and the unit of such farms would probably be about 5000 acres.

(5) We must ever bear in mind the importance of maintaining and increasing the number of our smallholders; they are an invaluable section of the agricultural community-both socially and economicallyand their sons as they grow up provide the best type of labour for the large farms. 'To secure the sound 
development of this movement, all new smallholders should as far as possible be settled in groups.

(6) Although the majority of our English tenants are in favour of the yearly lease, there is no doubt that the system of long leases could be extended with beneficial results; this system is common in Scotland.

(7) Although co-partnership farming and its close relation co-operative farming have not proved successful in this country, these forms of holding land should receive attention ; and it may be found that, with certain modifications, it is a system well worth considering.

(8) A further variation of the commercial farm is the experiment now being made by one or two landowners of turning their estates into a limited company, and the tenants into shareholders and members of the board of directors; this is mentioned here simply because it is a new departure-in a few cases it might be successful, but it would be difficult to find tenant farmers who would agree to such an arrangement.

(9) We want to bring in new blood to the agricultural industry, and every encouragement to come in should be given to those outside the present agricultural circle : (a) to business men with capital who would go into partnership with a highly trained manager-the partnership system of farming already referred to-and $(b)$ to men with little capital who would take up small holdings at home if obtainable, or settle overseas.

(I0) If the developments suggested in this chapter, both in regard to administration and tenure, are effected it means that certain sections of the present holders of land will be gradually squeezed out; the indifferent farmer will have to go-also the under-capitalized farmer.

Some will undoubtedly suffer hardship in the process ; 
but this will be minimized because the changes must be gradual. And many of those dispossessed, having realized their capital, can start on a smaller scale and therefore with a higher rate of capital per acre-which is one of the secrets of success. Others can find a haven on the land overseas and many of them should do well there, once prised out of the rut they are in at present.

\section{A LESSON FROM THE WAR}

The war has taught us beyond dispute that it is the farinaceous foods which it is so essential to grow at home, i.e. corn and potatoes. They are the most bulky form of food to transport, therefore in time of war their importation should be reduced to the minimum. 'They are arable land crops, and as shown in preceding chapters our proportion of grass land is altogether too large. Unfortunately we are not Nebuchadnezzars, wc cannot live on grass!

In times of peace we should prepare for the possibility of war ; food is the main munition of war, and if our food supply is known to be vulnerable it invites attack. The submarine in the next war will be much more formidable than in the Great War, when, fortunately for us, it was a new weapon. If perfected, submarine warfare could effectively blockade our coast for nine months and starve us out, unless we greatly increase the production of farinaceous food within the United Kingdom.

For the past sixty years, from March to September we have had generally only six weeks' supply of wheat in the country, sometimes less - a sort of month-to-month supply, unsatisfactory at best and a great danger in time of war.

In times of peace, even granted all Government 
control, it will be found wellnigh impossible to compel the farmers to grow the amount of corn we should grow. And I am certain it will be a grave error of judgment on the part of the Government to concentrate upon this.

Even the guaranteed prices for wheat and oats, fixed to safeguard the farmer against loss, will not materially increase the area under corn. I am all in favour of the principle of the guarantee; for it is a great step in the right direction for an English Government to recognize that the farmer must be guaranteed against loss, if asked to grow certain crops in the national interest. But we must not expect too much from the guarantee, rather must we attempt to create conditions generally favourable to arable cultivation.

The essential is to have the necessary area under the plough.

To secure this, the sounder plan will be to concentrate on increasing the area of arable land by encouraging the widest possible range of arable crops-lucerne, sugar beet, fodder crops (vide Harper Adams system), and above all potatoes; these crops are all excellent preparation for corn growing, and when a crisis comes the land is there ready for corn. We will now consider certain special crops which should be encouraged.

\section{CERTAIN SPECIFIC DEVELOPMENTS}

(I) Increased area under potatoes. Potatoes yield more, far more, farinaceous food per acre than any other crop. We have soil admirably adapted for growing potatoes, our climate suits the plant, and our potato farmers are the most skilled growers of potatoes in the world. Yet we only produce about five million tons of potatoes 
annually in the United Kingdom-just sufficient to meet the demand for table use.

In I9It the German potato crop was fifty million tons-ten times that of ours! And note that the German people only consume ten million tons as potatoes; the other forty million tons are used as raw material in the manufacture of a countless variety of commodities such as potato spirit, flour, starch, imitation corn starch, sago and tapioca.

The residuum, after making potato spirit, forms a valuable food for live stock-supplying the carbohydrates which we import in the form of maize from the Argentine and United States; and we pay over $£ 20,000,000$ for this annually.

Germany is well served with potato drying plants; it is only within the last few years that we have had any such drying plants in this country. Yet it is far more economic to dry the potatoes than to put them in " pies," covered with earth, as we do ; it saves a considerable percentage of waste, through potatoes going bad, and it saves the transport of thousands of tons of valueless water, for the potato contains over 60 per cent of water.

I cannot but feel that the $f_{2} 250,000$, advanced by the Ministry of Agriculture to encourage the development of home-grown sugar, would have been more effectively applied in developing potato production and its subsidiary industries.

Potatoes can form the mainstay in pig feeding, so that if this crop were properly developed we could have a much greater supply of home-grown pork than we had during the war; good pork is undoubtedly the most valuahle type of meat, for it supplies the essential fats, and how much we suffered from the bad quality of pork and bacon imported from the United States! 
Our pig policy during the war was perhaps the worst feature in our production.

(2) Pig-keeping. Another very interesting development is that of keeping pigs out of doors-no styes at all, just small and cheap wooden shelters in each wired-in run. These runs can be on quite poor land, woodland or poor grass land. Mr. Edge, on his Sussex farms, has proved what can be done in this direction. Not only do the pigs so kept thrive better and require 25 per cent less concentrated food (meal), but they are more immune from disease than pigs kept indoors ; further, they greatly improve the poor grass upon which they run. It is of very great importance to increase our " pig population." We have only about two million pigs in the United Kingdom, whereas we should have about sixteen million ; there were twenty-nine million four-footed pigs in Germany before the war. The pig should be regarded in a new light as the utilizer of waste spaces.

(3) Milk production. The supply of milk is altogether inadequate to meet the hygienic needs of the population. Were the supply doubled, the milk ration would still be a low one per head of the population. And a good milk supply is perhaps the most important single factor in producing a healthy and robust people. As already stated, the difficulty in regard to labour (milkers) may make the further development of the large dairy farm difficult, or even impossible; attention, therefore, should be turned to the small intensive arable dairy farm of the Harper Adams type, the object being so to crop the land that only two acres are needed to maintain a cow instead of four as at present.

(4) Sugar beet. A good deal of attention has been paid to this crop of late years, and the shortage of sugar during the war has been of great assistance to those who 
adrocate its development; that is why I include it in the list of possible developments. There is no doubt that we can produce sugar beet of a very good quality and with a heavy sucrose percentage; but it is a crop that requires much labour-can it be made to pay at the present high rate of wages? I am more than doubtful. It would be a great boon if it could be done, for not only should we have a home-grown supply of sugar, but the beet pulp-the residuum after extracting the sugaris very good food for stock. The cultivation of this crop is much the same as for mangolds, but from the farmer's point of view it has a great advantage-mangolds are sown in May and fed during the winter months to the live stock, which is not sold till the following year; so the farmer is not paid for his mangolds, except where they are used for feeding dairy cows, for a twelve-month or more. The sugar beet is also sown in May ; but the sugar factory buys the crop in the autumn, and the turnover is completed in six months. 'This is a great practical advantage; though it is one that the farmer will require educating up to before he fully realizes it.

The question is: will it be possible to induce the surrounding farmers to grow the 5000 acres of sugar beet, which is the minimum necessary to feed a factory? If produced under the four-year system it would require a total area of 20,000 acres, supposing each farmer to have one quarter of his land under sugar beet-which in practice would be impossible. Personally, I do not think the farmer will consider it an attractive proposition. The great argument for making every effort to introduce sugar beet cultivation is its beneficial effect upon the cultivation of the land. 'The development of the beet crop on the Continent was one of the chief causes of the general improvement in agriculture there. 
On the purely commercial side, the sugar factory, even a comparatively small one, is a costly affair-at pre-war prices $f_{100,000}$ was a conservative estimate. We have only one pre-war factory in the United Kingdom, and it has not done much. The one now under construction near Newark has already cost far more than the original estimate, and will probably cost $f_{500,000}$ by the time it is completed; it is hard to see how it can pay with the downward tendency in the price of sugar.

(5) Poultry. The high prices for eggs and poultry during the war have brought about a most astounding development in this department. The value of eggs

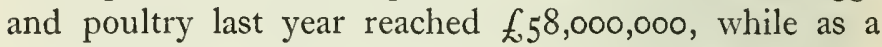
comparison it may be stated that our wheat crop was worth about $f 30,000,000$. It is to be feared that with falling prices people will lose interest in poultry rearing, and that there will be a decline; yet we are nowhere near the limit of what we could do with eggs and poultry, rather as a subsidiary side of general farming than as an occupation in itself.

(6) Lucerne and fodder crops. After the cereals and potatoes, lucerne might well be considered as potentially the most valuable and important single crop that we could grow and the area should be greatly increased, as also the area of the annual fodder or soiling crops, reducing the area under swedes and turnips to the needed extent.

(7) Stock breeding. We are justly proud of our pedigree stock; in this we lead the world; but when it comes to our average farm stock there is room for great improvement, both in the quality and in the way of handling the same. Let me recommend Mr. K. J. J. Mackenzie's excellent little book Cattle for further information in regard to this branch of agriculture.

It must be remembered that our export trade in 
pedigree live stock is very small, compared with the turnover of the agricultural industry; it does not represent more than + per cent on this turnover.

'I here are some progressive agriculturists who advocate the retention of our present grass area for this reason : the soil while under grass gradually stores up fertility, so that on account of our predominating proportion of grass land, we had in 1914 a greater amount of "stored-up fertility " than any other nation in Europe.

'This contention embodies a certain amount of truth, and should be weighed and answered.

The reply to it is :

(a) Tlat poor grass land, apart from putting a certain amount of humus into the soil, stores up very little fertility. It is only pasture rich in clowers that does this.

(b) 'That crops like lucerne store up more fertility than grass; and that, even where fodder crops under the Harper Adams system are grown, the land is still storing up fertility if the proper amount of farm-yard manure and artificials have been used.

(c) In a time of crisis it is much safer to grow corn after the crops mentioned in (b), than it is on newly broken-up grass land; for this land often has so many wire worms that the first, and even second, corn crop is a failure.

(d) Finally this point of stored-up fertility is not really of iniportance, if there is a good supply of artificial manure in the country. During the Great War the "stored-up fertility " stood us in good stead just because there was it shortage of artificials, but this shortage should not be allowed to occur again.

I have shown already that a larger head of stock can 
be kept on the mixed arable farm than upon the grass farm ; so that, if we handle our land properly and effect changes somewhat on the lines suggested above, we should produce a greatly increased amount of farinaceous food without diminishing our live stock.

The fundamental object is to obtain a higher yield from the soil, and to see that it gives employment to the largest possible number of cultivators living under good conditions. If this cannot be done under our old methods of cropping, these must be changed; we cannot let a fetish stand in the way of productive farming.

On the business side we must :-

(a) Create subsidiary and complementary industries.

(b) Organize our markets.

(c) Establish land banks to enable the tenant to purchase farms to his best advantage.

(d) Call credit societies into existence for short term loans.

(e) Organize and cheapen transport.

(f) Cheapen the transfer of land.

(g) Greatly increase the output of artificials and take steps to have our own supply of potash, which before the war came exclusively from Germany.

These are matters which inust not be overlooked, for they all aid in securing increased production.

\section{THE ADMINISTRATIVE SIDE}

Even if the nation, as a result of practical experience during the war, sets its face against the nationalization of the land, it will in future insist upon the land being put to better use than it has been in the past. It 
is important for agriculturists to realize the strength of this public opinion; and the Government, to comply with it, will be forced to interfere more and more, and we shall see a baneful development of official control. The Ministry of Agriculture Act, the Acquisition of Land Act and the Agriculture Act all combine to lay the foundation of a new land system. It is important to understand this point. Equally important is it to realize that if these measures are not successful-are not made successfulin creating a system under which the land will produce more food and employ more people, then more drastic experiments will be tried; of this I am convinced. Probably that new experiment will be in the direction of nationalization of the industry, as distinct from the nationalization of the land.

Experimenting with a great industry is always dangerous; and I cannot believe that, under any form of State management, the cultivator will ever give forth his maximum output.

The Government, therefore, should itself recognize that bureaucratic control will not secure progress; and that its special sphere should lie in providing the needed educational facilities, in supporting research, and demonstration on a commercial scale, and in organizing transport, markets, and access to capital.

As I have said already, the only alternative to official control, which is evil, is the control of the industry by the individuals composing it. 'This is sound and beneficial control; but it presupposes organization, and if the control is to be successful agriculturists must take a broad and national view of the question.

But what forces make for broad views more effectively than wide education and sound training? 


\section{THE AGRICULTURE ACT I920}

It goes without saying that labour must be associated in this control. The I9I9 Ministry of Agriculture Act establishes control and connects labour with it, for it secures the representation of labour on the various committees; it rests with the agriculturists themselves to say whether that control shall be official, or the co-operative control exercised by the industry itself.

The Agriculture Act legislates for many things that I have been advocating for years past; and it is only natural therefore that I regard it as the possible charter of future developments, if it is rightly administered.

There are two main sections-the one dealing with compensation to the tenant for disturbance, and certain provisions in regard to the landowner who fails to effect necessary repairs or to manage his estate properly; the other dealing with the cultivation of the land.

In regard to Part II, although I am quite in favour of fair and adequate compensation to the tenant, especially for capricious notice to quit, in justice to the landowner it should be remembered that for the last fifty years he has let his tenants have land at far below its economic value. And not only this, but he has rarely compelled his tenants to carry out the repairs to buildings which they are bound to do under the terms of their leases. Finally, the tenant farmer has benefited far more than the owner of land from the results of the Great War ; in fact, it is not too much to say that the landowners have suffered perhaps more from its effects than any other class.

It is the first part of the Act that is of supreme importance to the industry, and marks a new departure in legislation. It embodies two great principles : firstly 
that the labourer must receive an adequate living wage -that labour must be a first charge upon the industry ; secondly, that the producer must be guaranteed against loss if he is asked to grow certain crops, or maintain a certain proportion of the land under the plough, in the interests of the nation. 'This amounts, in practice, to the recognition of agriculture as a primary industry and that a flourishing home agriculture is essential to the well-being of the nation. But it is one thing - and a step in the right direction - to recognize a principle in theory, and quite another to live up to it ; time alone will show whether or not the Government and the nation are honest in their intentions.

Further, the Act makes provision for developing social life and amenities in rural communities. The importance of this cannot be over-emphasized, for the by no means necessary dullness of country life must be alleviated if we are to keep up and increase our rural population.

As to the machinery for carrying out these provisions, there are the Wage Boards; these were established in 1917 , and their powers are confirmed in the Agriculture Act. These Boards have been described on page 67 , et seq.

\section{THE MINISTRY OF AGRICULTURE ACT ${ }^{1}$}

The Ministry of Agriculture Act 1919, the recent Agriculture Act and, in a way, the Settlement Facilities Act are all so closely related as to make a single piece of legislation. The machinery for securing the proper cultivation of the land is laid down in the Ministry of Agriculture Act; and it has

1 See Apuenulix Do. VIII showing the present and the former arrangement of departments in the Ilinistry of Agriculture. 
called into existence the following committees and council :-

(1) An Agriculture Committee in each county. This is a sort of County Agricultural Parliament meeting quarterly, or oftener if need be; it has the power to divide up its functions and delegate its powers to :-

(a) The Cultivation Committee.

(b) The Small Holdings Committee.

(c) The Drainage Committee.

(d) The Live Stock Committee.

(e) The Agricultural Education Committee.

If these Committees are properly manned and worked, and if there is a reasonable amount of money to spend on wise developments, an almost limitless vista of progress opens up.

The Agricultural Committee is a statutory committee of the County Council, and to this extent official; and there is danger that County Councils which are urban in their composition may appoint unsuitable members upon this committee. The other section of members are those appointed by the Ministry of Agriculture; this, under the circumstances, was a necessary proviso -but here again there is a possible danger. If, for instance, a Labour Government were in power, men with extreme views and little practical knowledge might be appointed.

(2) The Agricultural Council of England and Wales. This sits in London and is the Agricultural Parliament for the whole country.

It is composed of representative members from the County Agricultural Committees, from the Wages Board, and of members appointed by the Ministry of Agriculture, selected to represent the interests of owners, 
tenants, women engaged in agriculture, and of horticulture and research.

The County Agricultural Committees came into being in October, 1920, and the Agricultural Council in December, 1920.

(3) The Adrisory Committee. A small committee appointed from the members of the Agricultural Council, plus certain nominated members. It is the Agricultural Cabinet if the Council be considered as the Parliament, and its chief function is to advise the Ministry on all land questions.

The machinery thus created is not bad, if it is properly worked. But the manning of the machine is entirely in the hands of official authorities-the Ministry of Agriculture and the County Councils. 'This is a danger. Even worse is the fact that the convening of the Council -save for its two biennial meetings-rests with the Minister, as also does the order in which subjects on the agenda are placed. These matters should be directly under the control of the Advisory Committee, if the Council is indeed to be a free parliament of agriculturists.

I have for years advocated the need for organizing agricultural opinion; but the organization should be voluntary and unofficial in its character. It should be based on the parish or district and work from the bottom up, not from the top down. ${ }^{1}$

Several attempts were made during the past ten years to create a voluntary-as opposed to official-and representative central council of agriculture, but none were successful; they failed to get the needed support. Thus

1. See Appendix $\mathrm{Xo} 1 . \mathrm{X}$ which shows in diagram form the Scheme for organzalion of atpriculeural opinion set forth an my lecture to the 1.ondion Schoul of Leonumics, March 10, 1016. 
the opportunity was lost, chiefly because agriculturists were not sufficiently organized to seize it; now all that we can do is to accept the situation and make the best of it. The voluntary organizations, by using their influence, must see that the right men get on the committees; and the right men must give up the necessary time and trouble to this important work.

If only all the existing voluntary organizations had been consolidated, and where necessary supplemented, the creation of the new official organization would not have been necessary.

I am dealing at some length with the Ministry of Agriculture Act ; for future developments will be largely affected by the way in which the provisions of the Agriculture Act are administered-by means of the machinery created under the former Act.

(4) This Act brought in another important change, it turned the Board of Agriculture into a Ministry of first-class status. For many years I had advocated this change, and most agriculturists used to inveigh against the inadequacy of the old Board; but, such is human nature, now that they have a Ministry with a large income they say "What can it want with so much money?"

Not many years ago the Board had the ridiculously inadequate income of $£ 250,000$ a year ; now the Ministry budgets over $£ 4,000,000$, and I feel that this is somewhat excessive-the swing of the good old pendulum. But we must be patient-it will take some years to get a personnel at the Ministry capable of spending such a large sum efficiently, and of exercising to the full its important functions.

The main function of the Ministry is to guide the changes, which must come in our agriculture, in the 
right direction--to the benefit of the nation and of the industry.

It can now spend far larger sums of money upon research, which is the first step in acquiring the requisite knowledge for subsequent developments. And we have seventy highly trained experts at work at Rothamsted, which is the oldest and greatest research station in the world. It is now under the able chairmanship of Lord Bledisloe, one of our hardest workers in the cause of agriculture. $^{1}$

The closest relationship should exist between the Ministry of Agriculture and the Agricultural Council; between them they should map out the routes of progress. Each Agricultural Committee also must keep the Council advised of its own local needs; and when the main lines are laid down it is through the Agricultural Committees and their sub-committees that the changes should be effected. Centralization would be disastrous; we now have the means at hand for decentralization, and the Ministry must show itself willing to decentralize if it wishes to attain to its fullest sphere of usefulness.

If these committees are to be effective, they must have adequate powers to guide the changes in methods of cultivation devised by the higher authorities. They must have power to deal with the considerable areas of grass land which, from the national point of view, should be permanently under the plough; again, there are large areas of grass in such bad condition that the only effective treatment is to plough them up, even if they are to be re-laid to grass in a few years' time.

Here we have the crux of the whole matter. The provisions of the Agriculture Bill on this head were very

1 baluable re warch work is b-ing done at Cambridge, Reading Lniversity and other plices. 
much modified by the House of Lords, and this from mixed motives : some of the members, if indeed not all, feared a recurrence of the unwise ploughing up orders that characterized the administration of a few War Executives-others, as owners, did not wish to see their grass ploughed up.

So that, as the matter stands to-day, the only chance of getting grass ploughed up-grass that should be ploughed up from every point of view-lies in the hope that the Cultivation Committees have indeed the power to secure this under the requirements of "good husbandry." It remains to be seen what will happen ; but if the "good husbandry" clause proves insufficient all our legislation and trouble will have been in vain, for then the elaborate machinery which has been set up will be of little use in securing agricultural development.

Above all, if the Cultivation Committees are to be successful, not only must they be composed of practical agriculturists but they must receive the backing of the mass of intelligent agriculturists in the country; and this implies, in the first case, that it is essential for the leading agriculturists themselves to be determined to see that the land is put to better use in the future, and increased production won from the soil.

Unfortunately there are large numbers of agriculturists who are opposed to any control or guidance of the industry; and who are satisfied with production as it is, so long as they are not bothered!

Yet the conferring of these powers upon administrative bodies is no new experiment ; rather is it the retaining, in a sounder form, of the powers given to the War Executives, which acted in each county as the agents of the Board of Agriculture (or of the Food Production Department) during the last half of the war. 
Certain modifications in these powers were no doubt necessary; but unless these committees have in fact the power to improve the standard of husbandry and gradually to introduce changes into our system of cultivation, in all common sense let them be abolished forthwith and let our agriculture sink into its grave!

The chief reason why drastic measures are so necessary now is that we had so lagged behind, and have much leeway to make good.

Undoubtedly some War Executives made mistakes, ordering grass land to be ploughed up which would have been better left down to grass. But the enemies of control magnified these mistakes a thousandfold, and deliberately closed their eyes to the excellent results achieved by these committees in many counties.

Through their efforts, bad and indifferent farmers were tuned up, unpatriotic farmers were prevented from growing crops which, while profitable, produced no addition to the food of the nation. And the net result of it all-one million and seven hundred thousand tons of extra farinaceous food were produced in 1918 ; thus bringing up our total yield, approximately, to the total production obtained in 1850 -the high water mark of our agriculture.

No mean achievement! And it was rendered possible by the hearty co-operation of our patriotic farmersi.e. the majority.

It is admitted that we have many indifferent farmers and that in consequence our land is not yielding the food it should; there must be guidance and control if this state of things is to be improved.

When control is talked of, it is often supposed that if applied at all it would be concentrated entirely upon arable land, or upon the effort to increase the area under 
the plough ; but the farming of grass land requires just as much supervision, for in most counties it is very badly handled. Managed on better lines it could carry much more stock than it does at present. While I advocate effective executive powers for the Agricultural Committees, I would stress "guidance" rather than "control "; the latter should be kept in the backgroundit is distasteful to the Englishman, both to the exerciser and to the recipient! To order the farmer to do this, or to do that, is the wrong procedure; in the first place he should be convinced by demonstration that the proposed changes in method are good business, and then he should be shown how to effect them.

One future development that seems fairly well assured is a much greater degree of combination amongst agriculturists. This is largely due to the difficulties with which we are now faced, and the fact that the official organization is not popular with farmers may lead to a more rapid and complete voluntary organization of the agriculturists.

The Landowners' Association is growing. 'The Labourers' Unions are expanding, and the increase in the membership of the National Farmers' Union is remarkable. If this body, working in conjunction with the Central Landowners' Association and the Labourers' Unions, will take the necessary trouble, there is no doubt that the County Agricultural Committee can be made a really effective machine to secure better cultivation and increased production. It is clear then that not only are the important principles, already referred to, incorporated in the Ministry of Agriculture Act and in the Agriculture Act, but these Acts should secure a hitherto unattained degree of organization of the administrative side, and also the decentralization which has long been needed. 


\section{TIIE OBJEC'TIVE IN PRODUCTION 175}

An industry in transition is always in a most critical state; and it calls for the most careful consideration on the part of the leaders of the industry to map out the course along which it should progress-for the practical leaders themselves should be the pilots and captains. If at wise selection is made in the representatives sent from the County Agricultural Committees to the Central Agricultural Council in London, then this body should be well fitted for the work of evolving an agricultural policy ; a policy which would prove a chart to the present sea of transition and would establish the new order in the industry.

But we must mobilize all our forces, and everyone with sound and constructive views should be enabled to contribute his share to the working of the new administration. And it is a good omen that the Ministry of Agriculture Act definitely lays down that labour shall be represented upon these new Executive bodies, and so will have a definite share in the reconstruction of the agricultural industry and of the conditions of country life. Quite a number of agricultural labourers who have thought deeply on the problem, and their contribution to the solution will be most valuable.

To the agriculturists who say "All we want is to be left alone," I answer that you cannot be left alone - the industry must be organized.

And not only the agricultural industry but the whole nation. The war has dealt so shrewd a blow at our national life that we are staggering under it, and our future trembles in the balance.

If the newly created committees and councils succeed in fulfilling their functions, this good should result : for the first time there will be an organized expression of agricultural opinion. And the practical agriculturists 
of the country will be in a position to put their views forcibly before the Government, before legislation affecting their industry is introduced, instead of after, as has been the case in the past. Whether the new developments will be successful or not time alone can show; it will depend largely on the spirit evinced by our farmers, and equally upon the Government keeping good faitl and not letting down the farmer-so destroying confidence.

Whether or not, under the new and revised system of cultivation, the land will prove to be able to pay an economic rental (to whom is not discussed here) and at the same time to pay the high rate of wages now demanded, will depcnd chiefly on the labourers themselves, on the amount of work which they give in return for their wage. If this work is economically insufficient then the land will revert to grass, for the farmer will be unable to afford the wage bill which arable cultivation involves, and we shall see our rural population shrinking still further, with a corresponding lessening in the production of primary wealth.

In regard to future developments let me recommend the following productions: Lord Selborne's Reconstruction Report (cd. 9079), Leslic Scott's Agricultural Opportunity, and The Future of Our Agriculture, by H. W. Wolff. 


\section{CHAPTER X}

\section{IMPERIAL CONSIDERATIONS}

T Chapter IV, I dealt with production from the soil of the United Kingdom and showed how 1 scrious is the present situation.

If we now extend our view to embrace the whole Empire, the conditions are still more unsatisfactory. In $19^{1} 4$ the agricultural population of white race (including all men, women and children living on and by the land) totalled $13,400,000$ - out of our entire population of about $62,000,000$-or only about 22 per cent. In France, with its total population of $36,000,000$, and an area only one-seventy-fourth the size of our Empire, the agricultural population is $18,000,000$. One more instance: the land of Germany, one sixty-fourth the size of the British Empire, supported an agricultural population of $21,000,000$ and, incidentally, in 1914 yielded as much produce as we obtained from the land of our whole Empire, excluding India! Let us carry the analysis of the agricultural population a step further. Of the above $13,400,000$, eight millions live in the United Kingdom; this leaves an agricultural population of only $5,400,000$ for the whole of our vast Oversea possessions. Can anything be more terribly inadequate? But it is worse than that-it is a grave menace to the future of our Empirc.

It is only necessary to consider these facts to realize 
how serious they are. They are facts, however, that are very little known; therefore the first thing is to bring them home to every citizen, and particularly to make the urban population realize their importance. We see the land of the United Kingdom producing barely half what it is able to produce; and the vast area of agricultural land in the Empire barely scratched.

Yet it is the produce of the land which, given in exchange for manufactured commodities, makes the wheels of industry move. It is only by the full development of our land that the over-pressure of population in our urban areas can be relieved and prevented. And it is only by increasing the number of cultivators of the soil that we can hope to develop the vast land resources of our Empire. It is no exaggeration to say that our future as an Empire, and as a race, depends upon our ability to increase the agricultural population by some six or seven millions within the next few decades.

It can be done, if the needed public opinion is created, and if the Governments of the Empire set themselves to the task. Seeing that we are already so short of agricultural population in the United Kingdom, it would help the problem little just to transfer agriculturists to our new lands overseas-in fact such a process would be disastrous to the Motherland. We want new agricultural population, and there are three sources from which it can come :

(I) Generally, from the rising generation by giving school instruction which will turn its thoughts towards a career on the land. And attention should be especially concentrated on the rural children, to check their drifting into towns-this has been done successfully in other countries.

(2) As many as possible of the children brought up 
at the expense of the State (in reformatories and under the Puor Law) should be induced to go in for a career on the land.

(3) By establishing training centres, and group settlements, for townsmen who would like to take up an agricultural occupation. There are many examples showing how successfully this can be done, provided there is careful selection.

If these measures are to be successful and a career on the land is to attract large numbers to it, the conditions of life in the country and the organization of the agricultural industry will have to be much better than they have been, or even now are, in the British Empire. Above all, the cultivators must be confident that they have the good-will of the nation behind them; and that the needed measures will be taken to secure them against loss. If the production of food entails a loss to the producer, the inevitable result is a reduction in the number of producers. The importance of this is beginning to be realized; but we have a long way to travel before we can catch up the nations which have given careful and ordered thought to the development of their land during the past fifty years.

And here we come to the root of the whole matter; things are as they are with us, because we have not given thought (let alone ordered or careful thought) to the development of the land.

We have given our thought to the development of urban civilization, with what success is open to question, and we have neglected our rural civilization. We have failed in development; for no nation can be said to be fully developed if one important side is left in only a partially developed state, and no degree of development of the other sides can compensate for this. 
This machine-made attitude of mind is fundamentally wrong; it has caused the neglect of the land, and the failure to understand its importance. This attitude has influenced the course of events in the vast Britains overseas, still mainly dependent upon agriculture, nearly as much as in the home country with its highly developed urban industrialism.

So that in our new countries oversea, in spite of the fact that they are still mainly in the "agricultural stage" (i.e. dependent upon agriculture), we see the over-rapid development of great cities and the neglect of the rural side. Instead of making every effort to develop the land and increase its production, much energy has been diverted to create and foster urban industries on a more or less artificial basis, and to this end tariffs have been imposed in an unscientific manner, with the resultant evil that the population is thereby encouraged to congregate in towns; capital also is invested in urban industries, which, from the national and imperial points of view, could have been much more soundly employed in the main industry-Agriculture.

Again, taking the last sixty years, we have had no migration policy and so have lost thousands of possible cultivators who have settled in countries outside the Empire. And during the same period we have had no organized policy of settlement ; so that the large majority of men who sought a career on the land were not placed or used to the best advantage-either in their own interest or in that of the nation. We must realize that the root evil has been that we have had no migration policy and no land settlement in the past.

Further, it is necessary to recognize that for lack of this policy we have suffered incalculable loss in manpower owing to the thousands who have gone to foreign 
countries; and in wealth because we have not striven to organize and settle our migrants under the best possible conditions. We left them to shift for themselves, unorganized and unassisted, and we have paid the penalty in the present under-developed condition of the land of our Empire.

Fortunately there are now signs that the importance of organized and scientific settlement is beginning to be realized.

But the crucial question is-do the people and the Governments of the Empire understand that this is the greatest problem that confronts us, and that the only solution is for the Imperial Governmentacting in unison with the Dominion Governmentsto concentrate upon the creation of a great Imperial Land Policy? I have dealt at length with these general considerations ; for it is necessary to bear in mind the question of developing the land of the whole Empire, and the relation it bears to production from the soil of the United Kingdom.

In June, 1920, Sir Herbert Matthews, the Secretary of the Central Chamber of Agriculture and a man who has worked heart and soul for the cause of agriculture, put forward the suggestion that the time was ripe for the formation of an Imperial Chamber of Agriculture.

And I agree with him that this would be desirable if it can be achieved; there is an Imperial Chamber of Commerce-why not an Imperial Chamber of Agriculture?

Such a Chamber would help to bind together the agricultural interests of the whole Empire, and prevent clashing; it would enable our agriculturists to present a united front to the world, and it could do much to hasten the diay of a self-supporting Empire. 
It would be a clearing-house for agronomic information, and could help in checking the over-development of this or that branch of agriculture within the Empire; equally it could draw attention to the need of developing the under-developed branches of the industry.

It could do useful work without any overlapping with the official departments suggested later in this chapter. It should be a source of inspiration, and provide that vision which is so lacking in official bodies.

The most pressing need, however, is for an Imperial land conference; not a conference at which the land problem would be discussed as a side issue, but one whose main subject would be the development of the land resources of the Empire. This conference should have been convened long ago-so pressing is the necessity for a clear inter-Governmental understanding on this subject : but the different Governments concerned fail to see that this is indeed the greatest problem of all the great problems with which they are faced to-day.

In the last cliapter it was urged that it is essential that such developments in our agriculture at home shall take place, as will put the United Kingdom beyond the danger of absolute starvation in time of war. In this the Premiers of the oversea Governments strongly concur ; no one realizes more clearly than they that the weakest point in Imperial defence is England's dependence upon sea-borne food, especially wheat.

We could have this security by growing more farinaceous food at home; and yet, at the same time, greatly increase our purchases of food from the Dominions. With an Empire comprising one quarter of the land surface of the globe, it is regrettable-to put it mildly-that we should be buying millions of pounds' worth of meat, butter, fruit, cotton and other raw material from 
foreign countries; and in our present financial crisis it is disastrous.

For example, and taking one case alone, in 1914 we bought $\oint_{5}, 000,000$ worth of tropical products from countries outside the Empire; we have vast areas of land within the tropics from which these products could come if a little thought were given to the matter. I an not pleading for a Zollverein, but rather for the wise and patriotic investment of British capital, and for some organization of the sources of supply.

Why invest millions in developing foreign countries, when the land of our own Empire stands in such need of development and would repay the outlay a thousandfold?

Why provide the capital which enables foreign countries-often countries in which there is much sweated labour-to compete with our own citizens, when that capital could be used in placing our own people upon our own land, thus increasing the production thereof and strengthening the Empire?

In spite of the war, there are still people who say that we must have cheap food, and cheap raw material, from whatever source it may come. Agreed, that we must have cheap food; but, if we make up our mind to do so, we can produce as cheaply within the Empire as in any other part of the globe. Unless, indeed, these people deliberately wish us to be fed by sweated labour, and from countries where the present producer may be producing cheaply by means of robbery-robbing the soil, and robbing the next generation, because they take all from the soil and put back nothing!

If one considers the question of our sources of supply there is only one conclusion that can be arrived at, viz.: the fact that we are not self-supporting as an Empire 


\section{THE LAND AND ITS PROBLEMS}

in all the main necessaries of life constitutes the gravest indictment of the policy (or rather want of policy) of the Imperial and Dominion Governments in regard to the development of our land and our agricultural resources.

A tour of the Empire must impress the traveller with the boundless natural resources of our land, also alas, if he uses his powers of observation, with the criminal waste on all sides. The area of land is so limitless! consequently little thought of, and wasted. Our forests were so vast--why conserve the timber? And so it was wasted; yet in many cases it cannot be replaced, for it was the growth of centuries. All this natural wealth and no comprehensive policy to develop it; millions of pounds spent in developing other countries, that should have been used to build up our own goodly heritage !

The fact is that few politicians in the Empire are qualified to deal with great questions of national and imperial economics; and the capable few are overwhelmed with the routine work of their office and have no time for these problems.

Our home officials have not sufficient knowledge to be of much assistance; how few of them personally know anything of the Empire save the part they live in ? This criticism applies to the officials in the Dominion Governments just as much as to those at home. These men may be capable of carrying out a policy, but not of devising one. They lack breadth of knowledge.

So that we come to this--our politicians can do little, and our Government departments can do even less, in the way of formulating the land development policy which is so essential. Every month of "drift" without the needed policy means incalculable loss to the Empire; a present loss and a still greater future loss. 
Ten years ago, in my book entitled Land Problems and National Welfare, I urged the need for an "Imperial Land Conservation and Development Board," and the need for it is greater still to-day.

There are many people who would like to see a fullfedged Imperial Parliament, but personally I do not think it feasible; the Dominion representatives would find it almost impossible to keep in close touch with their respective countries, and the Dominion legislatures would be very jealous of any super-Legislature.

And even if an Imperial Parliament were an accomplished fact, in all probability it would be in no way better qualified to deal with economic problems than the various existing Parliaments.

An Imperial Conservation and Development Board would be in an entirely different category ; its two main functions would be to guide the flow of wealth, in the form of human beings, to those parts of the Empire standing in greatest need of population ; and to guide wealth, in the form of capital, into the channels which would most benefit the Empire. It would in the widest sense secure "patriotic finance," instead of the German Jew system of finance which has held sway for so many years and which has been often actually anti-imperial.

This Board would have to possess certain executive powers which would need to be carefully thought out ; but as it would be the means of bringing further capital for the development of their resources to the Dominions, it is hardly likely that they would object to the proposal were it put to them properly.

The strongest objection to a new board or department is, that we are so overdone with departments, that there would be at this moment the strongest opposition to the formation of any new official Board. No donbt it would 
take considerable time to make the public understand the potential value of such a Board; nevertheless I feel that it is an objective to keep in mind and bring before the country; and definite efforts should be made to educate public opinion in this direction.

Shortly after the signing of the armistice an official Oversea Settlement Committee, under the Colonial Office, was set up. A certain proportion of the migration leaving this country is under the ægis of this committee, but it has not adequate powers. An Act is required to give greater powers to this committee and so further to organize migration; but the Act is hanging fire-other and more important (?) legislation must take precedence, and there is no time for it in the present session! I understand that the Government has such an Act in mind, and that it would be much on the lines of the Oversea Settlement Bill which was introduced in I9I9 and dropped. And although the I9I9 Bill in no way attempted to formulate a migration and settlement policy, nevertheless such a Bill, if passed, would confirm and strengthen the position of the existing Committee, which at present is only a departmental committee. Nominally it would be the Official Central Migration and Settlement Authority, and if it becomes so in fact and really does guide migration to the best Imperial advantage, it would not require much alteration to turn it into the Board for which I am pleading. But so long as it remains merely an Oversea Settlement Authority, large economic questions of development and conservation will be clearly outside its sphere.

If we accept the fact that, at the present moment, public opinion will not brook the formation of such a department as an Imperial Conservation and Development Board-of which Settlement would be an important 
branch-how are the pressing economic problems to be considered and solved ?

Let me repeat, at the present moment we have no men of official status giving proper consideration to these problems; and therefore we are living an absolutely hand-to-mouth existence. Can anything be more dangerous to our Empire and Kingdom ?

From this want of thought and guidance in economic questions a further danger arises. Great industrial, commercial and financial groups bring pressure to bear upon the Government, and often their case is stated so forcibly that they carry their point. It may be a sound development that is advocated, or it may be one that clashes with other and more sound developments; or it may be a scheme which, while beneficial to the group, is far from being so to the Empire.

It is all a lottery, and bad, because it is piecemeal.

We require, to meet the needs of the present situation, an Economic Council which would act as advisory to the Government, which would consider the different economic questions not only on their own merits but from the Imperial and National points of view.

And it should not be like the advisory committees which were rife during the war, which only considered questions (often superficial) as they were submitted by the Departments concerned.

This Economic Council should be composed of a small group of leading economists and patriotic financiers, and should have the power to formulate economic policy and submit it to the Cabinet. This Council would really be the "thinking department" for the Empire and Kingdom. It would confine itself to the consideration of fundamental problems.

We must have an economic policy without delay if 
we are to consolidate the Empire and if we are to develop it and retain it for the English-speaking race.

Without the needed policy we shall suffer each year an ever-increasing loss, and-it is not putting it too strongly-we shall imperil the very future of the Empire. And to give effect to such an economic policy I maintain that some form of Conservation and Development Board is essential. It is impossible to work effectively through the medium of half a dozen different departments.

The guiding principle of this economic policy must be the need of developing the rural side of our civilisation.

The great mistake of the past century has been that all attention was concentrated on urban development; our civilization was based upon industrialism, and upon a school of economy as hard and inhuman as the metal machinery which made the industrial development possible, and brought in its train overcrowding in our towns, with their congested slums and high percentage of unemployment and families living on the verge of starvation!

These are not achievements to be proud of, if regarded impartially, and all the time with the millions and millions of acres of undeveloped land lying under smiling skies and calling aloud for cultivators! And we must not think solely of the material side, of the importance of increasing primary wealth; there is the mental and moral side as well.

The value of living on and by the land is great in the building up of character, and in giving soundness of judgment.

The most healthy life for the human being, bodily, mentally and spiritually, is the life on the land under the direct influence of Nature ; all else is, in a greater 
or less degree, artificial and therefore in a corresponding degree unhealthy.

Even in our young sister countries overseas we already see the evils of the over-large urban populations becoming a menace to their future; yet we have done and still do nothing to counteract the overgrowth of the towns by building up the countryside.

Other nations for years past have perceived this danger and have taken measures, largely successful, to increase the rural population, and to improve the conditions under which it lives.

We, too, must reverse our evil policy of the past and concentrate upon the rural side, if our Empire is to survive the century.

Finally, we must have a carefully thought-out economic policy if we are to achieve a "self-supporting " Empire -an ideal by no means beyond attainment, which should stir the heart of every patriotic citizen. 


\section{APPENDIX I}

\section{RENT}

T $\mathrm{T}$ may be useful here briefly to describe the nature of rent in agriculture. Some land pays higher rent than 1 other. Such rent marks a superiority and greater productiveness.

Rent of land in agricultural cases is simply the price paid for the service and hire of land, and it measures some advantage over other land with which it is contrasted as regards utility. The amount varies on different plots for several reasons, mainly (I) superior quality or productiveness, (2) accessibility and convenience or some other economic advantage which renders it relatively more profitable.

In the simplest case the rent will be the lowest rate as determined by supply and demand.

Superior fertility (productiveness) will command a higher rate of rental in proportion to its higher yield. This superiority of soil may be natural or it may be the result of outlay upon the soil as in fertilizing, draining, etc. In the first case a higher rent will arise from natural advantages, and in other cases it may be due to expenditure upon the soil in order to render it more productive: the higher rent is then regarded as interest on capital sunk in the soil, and it is properly a return on outlay of capital.

Thus we have land which is more productive by nature's gift of high fertility, and also from advantage of site or access, water supply and other incidental advantages; sometimes from mineral wealth. These cases yield extra rent, but this 
does not arise from outlay of capital or labour, but is due to endowments of nature.

These advantages produce higher rent to the owner above the rent which is derived from poorer or less richly endowed soil.

In the above paragraphs I have been dealing with the theory of rent. Our great cconomists, from Ricardo onwards, have dealt at length with this problem, but very generally from the academic and theoretic side.

Sufficient attention has never been paid in this country to the human element as a factor in determining rent, and the general result of the teaching of our economists has been an exaggerated belief in the rent value inherent in the soil. Even in the case of the richest soil it has become available for agricultural use only after the expenditure of capital.

It was this belief in the inherent or prairic value of the soil that led to the Land Value legislation, which failed because it was based on a fallacy. Investigation shows that in practice the inherent or prairie value of the land is non-existent.

The effect of the teaching of our cconomists has been farreaching, and has undoubtedly led to the attitude of mind amongst our practical agriculturists who hold that for market gardening, for instance, you must have good rich land; the idea of making the soil hardly exists in this country as it does in others. As an example, the wonderful market gardening near Paris is on land that was of the poorest possible quality; but the cultivators "built up" that land to such an extent that each year they have surplus soil which they sell, and the writer has talked to men who pay their rent by selling surplus soil!

As a side issue in the problem it is interesting to note the difference between the rural and urban landowner in regard to rent. The urban owner as a rule does not expend his capital in developing his land; another man generally builds the house upon it, a public authority does the drainage work and lays on the water supply.

In the case of agricultural land it is the owner who effects 
all improvements out of his capital, and generally speaking these improvements, houses, roads, fences, drains, etc., which have been effected, say, within the period of the last fifty or sixty years represent an amount of capital equal to the selling value of the land. If a man buys a farm he is either paying for the value of the improvements and nothing for the land, or if he likes to say he is paying for the land itself, then he is paying nothing for the improvements.

In fairness to the agricultural landowner this distinction between himself and the urban landowner should be borne in mind when questions of rent are discussed.

In the writer's book, The Land and the Empire, published in 1917 , he attempted, with much diffidence, to give a definition of rent from the purely practical point of view : this was as follows :-

"The price of land and the rate of rent is fixed by the value of the land to the cultivator, influenced by the consideration : Can he make his living off land bought or rented at a given price? And although the law of supply and demand undoubtedly affects the price of land, it is much more affected by other considerations, for example, the standard of skill, intelligence and energy of the race of cultivators, the presence of conditions favourable to the industry and the state of organization of the industry."

Some two years later the writer read List's National System of Political Economy, in which the question of rent is dealt with in an interesting way, and from the practical rather than the theoretic point of view he says :

" Ricardo, and after him Mill, M'Culloch and others, are of opinion that rent is paid on account of the natural productive fertility inherent in the land itself. Ricardo has based a whole system on this notion. If he had made an excursion to Canada he would have been able to make observations there in every valley, on every hill, which would have convinced him that his theory is based on sand. As he, however, only took into account the circumstances of England he fell into the erroneous idea that the English fields and meadows 
for whose pretended natural productive capability such handsome rents are now paid, have at all times been the same fields and meadows. The original natural productive capability of land is evidently so unimportant, and affords to the person using it so small an excess of products, that the rent derivable from it alone is not worth mentioning. All Canada in its original state (inhabited merely by hunters) would yicld in meat and skins scarcely enough income to pay the salary of a single Oxonian professor of political economy.

"The national productive capability of the soil in Malta consists of rocks, which would scarcely have yielded a rent at any time. If we follow up with the mind's eye the course of the civilization of whole nations, and of their conversion from the condition of hunters to the pastoral condition, and from this to that of agriculture, etc., we may easily convince ourselves that the rent everywhere was originally nil, and that it rose everywhere with the progress of civilization, of population, and with the increase of mental and material capital.

The basis of rent is the exclusive benefit or advantage which the ground yields to that individual at whose exclusive disposal it is placed; and the greatness of this benefit is determined especially according to the amount of available mental and material capital in the community in which he is placed, and also according to the opportunity which the special situation and peculiar character of the property, and the utilization of capital previously invested therein, affords to the person exclusively possessing the property for obtaining material values, or for satisfying mental and bodily requirements and enjoyments." 


\section{APPENDIX II}

\section{NEW MOVEMENTS IN RURAL EDUCATION}

(A Paper zuritten by the Author in 1916 before the Fisher Act was introduced)

I

$\mathrm{N}$ this paper I propose to discuss certain new movements which have already been started to a certain extent in our elementary schools and in Farm Institutes, etc., or which during the past few years have been suggested by such bodies as the Consultative Committee of the Board of Education and the Rural Education Conference. But before discussing these movements I would like to make certain general observations in regard to Education, particularly in view of the conditions which the great war we are waging either has created or will create.

It is almost impossible to forecast what the condition of the country will be in another year's time, so that anything approaching prophecy should clearly bc avoided. But this at all events is clear, no matter what measure of victory is vouchsafed to our arms, the period of recuperation must be a lengthy one. Indeed, if we are to recuperate at all, every individual citizen must do his very utmost and must be as effective and efficient as possible ; therefore it will be necessary for us to leave no stone unturned in our effort to train the rising generation to become the most effective citizens and the most efficient workers possible.

I want to lay great stress on the point that the basis of efficiency lies in sound education. From the national point of view nothing will be more disastrous than to adopt a policy 
of false economy in regard to education. Let us make drastic changes if they be necessary, let us stop expenditure on the non-essentials in education and see that every penny is well spent, but let us remember that it is only by spending sufficient to secure sound and practical education that we can hope to recuperate after this disastrous war-that we can hope to make head against the increased competition of the United States and Germany itself. Germany is a highly organized industrial country, and after this war its incentives to increase production will be greater than ever.

In the past we have spent large sums on our elementary education. Much of this money has been wasted because instruction has been too "bookish," in the bad sense of the word, and not sufficiently practical. Secondly, because of the scant provision for continuation instruction, much instruction that has been so costly to provide has been entirely lost. We sec children going in for technical courses at the age of sixteen who cannot benefit to the full by these courses because their general education is bad-because they have forgotten so much of what has been taught them. Other countries are far better provided with continuation instruction than we are, and even in the case of the children of labourers it is very generally carried on to the age of sixteen and even eighteen.

To consider the case of the countryside, this war has still further depleted our rural population. A strong and flourishing rural population is the first essential for the welfare of a country, so that henceforth our chief aim in education must be to teach the importance of country life from the national point of view, and to instil more and more a love of it in the rising gencration hoth in town and country schools. I adnit that from the lahouring man's point of view country conditions have in the past been most unsatisfactory and the opportunities for betterment too few. These conditions must be changed, and I am convinced that they will be changed ere long to such an extent that the teachers themselves will feel justified in using their influence to direct the inclination 
of their pupils in favour of a country life ; many teachers are already doing this. It is very largely in the hands of the teachers to guide the future development of the rising generation. This is a power which they should use to the full, but they should carefully study what is necessary and desirable in that development from the national point of view.

Before coming to details concerning Rural Education I would like to make the following points clear so that there may be no misunderstanding of the point of view from which I am approaching the problem :-

I. I do not want to see our rural elementary schools turned into agricultural schools, but rather that onc day our rural children should have educational facilities equal to those enjoyed by town children.

2. I do not want general education to be narrowed, but rather to see it made more full and more effective than it is to-day.

3. Nothing should be done that would lessen the opportunities of the children at school or check them in the free choice of their future career.

4. Though I advocate a great development of manual instruction, this must not be at the cost of the literary side. The most priceless boon that education can give is a real love of books-a boon which, alas, has not been effectively given by our text-book education in the past.

In reorganizing any system of education the great point to bear in mind is what type of citizen the country stands in greatest need of, and the qualities of mind with which he should be endowed, and then deliberately to set out to obtain that end.

First of all we want citizens who have the fear of God within their hearts, and a lively sense of their duty to their country and to their neighbours.

Secondly, we want citizens who can think ; and

Thirdly, we want citizens who can use their hands intelligently. Nothing gives a greater grasp and understanding of the conditions of life than being able to do things well. 
In the past our education has tended too much to turn out a disproportionately large number of clerks and unskilled workers.

When the fact is recognized that our present system of education turns out a larger proportion of unskilled workers than any other system of education, I think it will be granted that to reduce in the future the number of unskilled workers and to increase the number of skilled cultivators of the soil will be to the national advantage. When, further, it is realized that the total white agricultural population of the whole British Empire is seven millions less than the agricultural population of European Germany, it will be admitted that the type of citizen, above all others, that we need, to secure the future development of the Empire and the Homeland, is the tiller of the soil. It must not be forgotten that fifty years ago the land of the United Kingdom carried a far larger population than it does to-day, and that there is, therefore, ample room for a large increase in our rural population.

Of the new movements in education that have already been put on foot, the most striking is the development of manual instruction in the elementary school. Nuch has been done during the past decade, but still in the vast majority of elementary schools the manual method has yet to be introduced. In theory it is admitted that instruction is only full and complete which appeals to the manual as well as the mental activities of the child, but it still remains to put this axiom into practice in all our elementary schools. Too much lip service is rendered: there is not sufficient whole-hearted effort directed towards giving the rising generation that type of instruction which we believe will turn out the most effective citizen in whatever career in life he may choose. Simple manual instruction could and should be given in nearly all elementary schools under existing conditions and at a very small cost. We must not wait for perfect equipment, we must not wait for special manual instruction rooms. Every local education authority should concentrate on developing manual instruction for boys and girls in all the schools within its 
area. Five years' experience in the Lindsey division of Lincolnshire has proved that three afternoons in the week can be given up to manual instruction with the greatest benefit to the general education of the child. It has been proved that the literary side of the child's education itself derives benefit from this arrangement, and there is no doubt that the child leaves school with his faculties and capacities better developed than was the case before the introduction of the manual method. The term "Manual Method" is used to show that more is meant than merely the addition of one or two manual subjects to an already overcrowded curriculum.

The "Manual Method" means the utilization of handwork in an educational rather than a vocational manner. It means making handwork part and parcel of the very life of the school, not merely the tacking on of a handicraft subject taught perchance by some outside craftsman unable to give it educational value. Hence the importance of a handicraft being introduced only into schools where the staff itself can teach it. Ordinary text-book instruction appeals only to one side of the child's brain-and in the case of dull children often fails to appeal at all ; but handwork appeals to all children. Through it the idea of form, colour, quantity, number, become realities, so that the bookwork acquires reality also. Through it the ideas forming in the child's mind, as the result of what he has seen, heard, and read, find actual and concrete expression.

Thus bookwork of the right type and manual instruction woven together form the "Manual Method" and appeal to the whole child, to all his activities, mental and manual; and in the case of dull children it has proved the means of stirring their mental activities by teaching them to use their hands.

There are 100 schools in Lincolnshire where this method has been developed. The cost to the county is only some $£_{250}$ a year. The chief danger to be guarded against is that of a teacher giving manual instruction who is not qualified to do so. The number of teachers so qualified is much larger than is generally supposed, and the number can be rapidly 
increased by the proper use of Saturday and holiday courses of instruction for teachers.

The county of Cambridge gives a brilliant example of the full development of these courses, with the result that in every school in the county all practical processes of home management are admirably taught ; in most countics the tendency is to concentrate more attention upon giving boys this manual instruction, and the girls in this respect are sometimes overlooked; but in Cambridge it is rather the reverse. This county is doing most valuable work in showing what can be done in manual instruction for girls. It is essential that our future housewives and mothers should be taught the elements of home management at school, for they can as a rule learn it nowhere else.

I will not go into detail as to subjects and methods. But the guiding principle should be that the manual instruction must be given by a member of the actual school staff, and here I would like to refer you to the leaflets published by the National Scheme of Handwork Committee.

From what has been said, it is evident that the personality and qualifications of the teacher are matters of supreme importance. In the past the curriculum of the training college has been far from satisfactory; in theory the importance of manual work was admitted, but at the training college manual subjects have been more or less optional, and in no way have received the attention that their importance demands. There is little doubt that manual subjects will become more and more an inherent part of the training college curriculum. But we must remember that even to-day a large number of future teachers do not go through any college. It is therefore most important to develop the other methods of training teachers. All teachers ought to go through a college or university course; but the training they are to receive after they leave school and before they go to the college is a matter deserving of the closest attention. A few years ago the cffort was made to induce all would-be teachers, on leaving the elementary school, to go on to a secondary schoul, but in country districts 


\section{THE LAND AND ITS PROBLEMS}

this proved to have a deterrent effect and the numbers going in for the profession decreased to an alarming extent. The Board of Education then revived the pupil-teacher system in a modified form, and at once an increase in numbers was observed.

Still the situation is serious; to keep up the supply every local authority ought to have a number of students training to become teachers equal to 6 per cent of the teachers it employs. Unfortunately, few authorities are maintaining anything like that ratio, 2 or 3 per cent being the most common average. It is sad to have to say it, but the large and rich urban authorities such as London, county authorities such as Lancashire-are the worst delinquents ; they are deliberately keeping up their supply of teachers at the cost of other authorities, often much poorer than themselves, who are doing their duty in the way of training teachers. It is most important to keep up the proportion of rural boy and girl students ; if we are to have the right atmosphere in our country schools we must have the full proportion of country-bred teachers.

Wherever there is an exceptionally good rural school in which the manual method is fully developed it should be utilized as a training centre for pupils destined to be teachers. They enter this centre on leaving the elementary school, and one great advantage is that, at the end of, say, two years, the head master can judge whether or not this or that pupil has really in him the making of a good teacher, and if he has not he can be withdrawn without waste of time or money.

To come now to suggested new developments, the first and most important is undoubtedly that of continuation instruction. A certain amount has been done in this direction in towns by evening schools and technical classes; but in many towns, particularly those of medium size, the ground is by no means covered. In rural districts there is very little continuation instruction, and what exists is chiefly in the form of evening schools that do not mcet the need of the labourers' sons who have been at work all day in the fields and who live perhaps at a considerable distance from the school. 
To bring the standard of technical skill up to that which exists in Germany or Denmark, for instance, it will be necessary that a larger percentage of the rising generation go in for technical classes; but there is little use in providing technical and scientific classes entirely detached and divorced from the instruction given in the elementary school, and that is why the connecting link must be forged. The present gap in our system of national education must be filled by a system of continuation instruction which will carry on and complement the work done in the elementary school, which, though it might he more definitely vocational, must still not overlook the need for general instruction and particularly must kecp in view the fostering of a real love of reading. It is one of the saddest things to see how little books are appreciated in the rural districts; yet how much could they add to the life of the cultivator of the soil.

There is on foot an agitation for raising the school-leaving age to sixteen. I fear the exigencies of the time will cause this to be indefinitely postponed. It would be too costly. But if a proper system of continuation instruction is provided the delay need not be so much regretted. And in the case of children going in for a career on the land I think that leaving school at fourteen, with continuation instruction, is the ideal to aim at. It has been pointed out that as the evening school does not provide a suitable means of continuation instruction in the case of rural children, a system of centralized continuation day schools must be devised to which the children, boys and girls, must be brought for one morning or one afternoon in the wcek. $A$ first-class master is essential ; and even with classes not exceeding twenty in number he could instruct some 100 or 120 pupils in the course of the week. The employers of lahour would have to give facilities for this arrangement. They do so willingly in countries where this system has been established, and there is no valid reason why they should not do the same here. 'The trouble is, alas, that most employers in England so little understand the value of educatic, that they undoubtedly will make difficulties, and compul- 
sion may have to be resorted to. It is extraordinary that employers do not generally recognize what an advantage it would be to themselves to raise the standard of intelligence of those who work for them. We have brilliant examples of certain clear-sighted manufacturers who have established schools actually in their own factories, and who insist upon all youths under seventeen attending for so many hours a week. We badly want to see the same spirit actuating all employers of labour.

This system of centralized continuation day schools has been recommended by the Consultative Committee of the Board of Education and the Rural Education Conference, and it has been in operation for some time in Canada and other countries.

To come next to instruction of a more purely agricultural character and available for boys and girls after the age of sixteen is reached: three years ago Mr. Runciman brought in various changes and developments, the result of which has been to give us a system of agricultural education. Before that there was no system at all; and although there is much room for future development, we may well be thankful that at last a beginning has been made.

England was divided for the purposes of this agricultural education into twelve provinces, with an Agricultural College situated in each ; this college forms the centre of agricultural education for the province.

Further, the county councils (though by no means all) have appointed agricultural organizers, and these, with their assistant lecturers on the county staff, control what may best be termed the intermediary agricultural education of the county. The results are clearly good; the farmers' interest is being aroused and their sons are becoming anxious to go in for courses of instruction. Instruction is being brought to the farmers.

But the grave defect is that so far it is not reaching the children of the labourers; and they must be reached if we are to have more efficient workmen on the land in the future. 
I do not think it will ever be possible for many sons of labourers to go on to the Agricultural College ; still the exceptionally clever youth should have the opportunity of doing so, but in the past we have been too apt to think of the exceptional cases and to neglect the importance of raising the general standard. And the continuation day school will prove the easiest way of reaching the sons of labourers; and when this is once attained, I am convinced we shall see a very great improvement in the standard of our agricultural labourers.

In the main, labourers' sons will continue to learn the technical processes on the farms on which they work-or rather they should do so ; but unfortunately the farmer, as a rule, is a very bad teacher, so that it may prove necessary to develop low-grade centres for agricultural instruction where short courses on the care of animals and the rudiments of agriculture could be given.

To provide continuation instruction for girls these lowgrade centres would be most valuable. They have been started within recent years in Germany, and they do in a measure for the daughters of labourers what the "Ecoles Ménagères Agricoles" do in Belgium for the daughters of the better class of farmers. Supposing the elements of practical home management to be taught in all elementary schools, girls on leaving would go on to the low-grade centre for a three-months' course in what might be described as " Agriculturized Home Management."

\section{The Houseroife.}

(a) Duties of the housewife-moral, social; principles of domestic economy.

(b) Instruction relating to infants and children.

(c) Hygiene, care of invalids.

(d) The care of the house-furniture, utensils, etc.

(e) Feeding the family, comparative values of foods, using the produce of the farm and garden.

(f) Cutting out, making, repairing clothes and linen.

(g) Washing. 


\section{THE LAND AND ITS PROBLEMS}

2. The Woman in relation to the Farm.

(a) The domestic animals, dairying, rabbits, bees, etc.

(b) Agriculture (a few underlying principles), the soil, manures.

(c) The housewife and the garden.

3. The Country-Woman and Society.

Clubs, Women's Institutes, Co-operation, etc.

This course would really follow up and amplify the practical work done in the elementary schools. Particularly in the case of girls, we have made a great mistake in specializing in this or that subject. Too often a girl goes out to the Colonies or to settle on a farm at home, who perhaps has been taught to make butter, but who knows nothing at all about the feeding of cows, or the causes of butter having a bad taste, or the ways of handling and keeping butter.

The first object should be to turn out women who know how to use their hands intelligently, and who know how to manage their homes well; afterwards it will be time enough to add proficiency in special subjects.

If we are to attract the rising generation to a life on the land, we must resort to such associations for the brightening of social life as Farm Lads' Clubs, and Women's Institutes, which have played such a part in the brightening of life in the country districts of Canada. Co-operation must be encouraged; for at present we are far from possessing an organized rural society, we have not even a society inchoate.

Mr. Russell, the Irish poet, seer, and practical reformer, puts this so well that I must quote his words :

" Our rural populations are no more closely connected for the most part than the shifting sands on the seashore. There are personal friendships, of course, but few economic or social partnerships. Every one pursues his own occupation without regard to the occupation of his neighbours. If a man emigrate it does not affect the occupation of those who farm land about him. They go on ploughing and digging, buying and selling, just as before. They suffer no perceptible economic loss by 
the departure of half a dozen men from the district. A true community would, of course, be affected by the loss of its members. A co-operative society that loses a dozen members, the milk of their cows, their orders for fertilizers, seeds, and feeding stuffs, receives serious injury to its prosperity. "That is the difference between a community and an unorganized population."

Local Education Authorities must actively develop these things; they must understand that they are responsible for the standard of the people living within their areas; they must realize that deep down in every heart exists a love of the land and a desire to work upon the land if conditions are reasonably favourable, and this is not merely for material rcasons but for spiritual ones also.

Rural land means the material object through which certain fundamental spiritual needs of man can find satisfaction. We want to foster and develop that call of the land, not only for the physical and spiritual development of the people, but for the very consolidation of our country and our Empire.

I have shown how disproportioned is our agricultural population compared with the vast land area of the British Empire; we must encourage more of those now being educated to go in for a carcer on the land at home and overseas. To this end all industrial schools and reformatories should have farms attached to them; some of these are already turning out excellently trained agriculturists, but the proportion of these should be greater. Again, I think that much more should be done to influence the children under the control of the Poor Law Authorities to go in for a career on the land. In Austria, where the boarding-out system is universal, practically all the Poor Law children become agriculturists. We have here been occupying ourselves with the elementary schools and the children of the worker. But equally I feel that the science instruction in our great public schools and secondary schools stands in need of revision, so that every one who will ever be connected with the land should know about land; and this, alas, is very far from being the case at present. I have only been able to throw out ccrtain 
suggestions and to make a cursory review of certain sections of the education problem.

To sum up the main headings-

I. Much greater attention should be paid to developing as speedily as possible manual instruction in the elementary schools.

2. An effective system of continuation instruction must be devised without further loss of time if we are to render the other parts of our present system of education effective.

3. Lower-grade centres for agricultural instruction should be established.

4. Farm Lads' Clubs, and Women's Institutes should be created.

5. Agricultural instruction in Reformatories and Industrial Schools should be developed.

6. The science in our secondary schools should be revised, and Botany and the Chemistry of living things substituted for Inorganic Chemistry.

I am not suggesting that these developments could take place all at once throughout the United Kingdom, but I do urge that the time for experiment has more than come; some of these experiments will undoubtedly cost money, but particularly in regard to elementary education much can be done by alteration and organization, and at a comparatively small expenditure. 'The great thing is for us to be determined to get a sound and practical education for the money we expend, and we must never for one moment forget that money spent on the right type of education is the soundest and most remunerative investment into which a nation can put its money.

\section{THE FISHER ACT}

Since the above was written Mr. Fisher's Bill has been introduced and is now an Act of Parliament.

It is one of the greatest and most comprehensive enactments ever passed by any Government.

Under it there is the opportunity for developing nearly every suggestion contained in the foregoing paper. Eight hours weekly of continued instruction is provided for. 
It is true that many ardent educationists consider this to be insufficient and adrocate twenty hours weekly. But it must he remembered that even eight hours per week is more than is given in most countries where day continuation schools have been in existence for some years; that it will require vast effort on the part of Central and Local Authorities to make adequate provision for cight hours' continuation instruction a weck; and that finally, when we have the new machine working smoothly, it will always be possible to increase the number of hours.

Not for one moment must we lose sight of the fact that if the new developments are to be successful the first essential is to concentrate attention on the training of the future teacher. Two years' training in a college is not sufficient-three years should be the rulc and not the exception.

And more and more the training colleges should be given a university character and atmosphere.

In regard to the actual creation of the continuation day school, a perfectly possible procedure in any county would be to select so many of the best and largest of the elementary schools, add a cheap wooden class-room, and appoint either a "continuation master" or put the elementary school head master, if suitable, in charge of the continuation school as well, increasing his staff as necessary. This would be the continuation centre to which children within a three-mile radius would come. My own county is not thickly populated, but study of the Ordnance Map and of the population between the ages of fourteen and eightecn shows that a good continuation attendance could be secured at a good many centres.

In the early stages of the movement the object should be quality rather than quantity. One centre properly run, full of intellectual life and educational activity, will be worth half a dozen indifferent centres. We must do more than simply create continuation day schools : we must call into existence centres of intellectual activity that will permeate the life of the whole neighbourhood. The best elementary schools would provide a good nucleus, also the small rural secondary 
schools, and later on, where necessary, the formation of continuation schools, independent of any existing school.

The head master of a continuation centre should be highly paid, so that these schools would be regarded as prizes in the teaching profession, and attract good teachers. Further, opportunity should be taken of the educational reorganization to improve the social status of the teachers-higher salaries will help-but more is needed. Every county should have a system of social gatherings for teachers. These might talse place in the summer holidays, and in country houses lent for the purpose. They might last for three or four days, and while chiefly recreational, a few conferences and lectures on educational subjects could be fitted in.

It is now time to consider what is to be done in the remoter areas lying out of easy reach of the centres.

(a) Much could be done by conveying pupils in motorlorries, which presumably will be plentiful after the war.

(b) By establishing a system of peripatetic teachers, who would take continuation classes wherever ten to twenty pupils could be got together.

At the outset little should be spent upon buildings. Any existing room, or cheaply erected wooden room, should be used until experience indicates exactly what is wanted.

There is no getting away from the fact that the provision of properly qualified teachers will prove to be the great difficulty - but not an unsurmountable difficulty. The supply will come with the demand just as it did in the early " seventies " of the nineteenth century-that other great period of educational change and reorganization. Further, every L.E.A. must concentrate attention on training teachers.

The next question is that of the curriculum. Here great elasticity will be needed. The curricula must vary with the varying conditions of surrounding life. In general terms, in rural districts instruction will have to be more general in its character than in the town continuation school ; there will be less opportunity for specialization or for a wide range of vocational work. 
Of the eight hours a week, one hour should be given up to physical instruction. This should include teaching the pupils how to lift weights. There is a right and a wrong way of attempting to lift a weight; to lift it wrongly may entail serious physical injury. For example, the larger proportion of agricultural labourers suffer from rupture because they were never taught how to lift. Also many labourers are hammer-toed, because it is very generally assumed that after eighteen the foot does not increase in size! These may seem small points, but they are of great importance in securing the physical fitness of the rising generation.

Of the remaining seven hours, three and a half, if not four, should be given up to literary work. It is essential to raise the general standard of knowledge; it is essential to instil a real love of books, for nothing would add a greater interest to the lives of those living in country districts than a keen and intelligent interest in books.

The last three or three and a half hours should be given up to manual work. Here such specialization as circumstances permit might come in. From the age of fourteen to sixteen the educational aspect of the instruction might still dominate -from sixteen to eighteen the work might become more and more vocational.

Even in the clementary schools we must get away from the idea that education must be confined within the four walls of the school-house. "All the world's a school." Everyday life outside the school should definitely be made to play its part in educating the child. If this is true of elementary education, much more is it true of continuation instruction.

The teacher should bear in mind the work and manner of life of each pupil, and relate the instruction given thereto. For instance, in the case of a lad on the farm, somehow or other we should make him understand the simple principles underlying every process he performs. Rarely can the farmers teach this - they have little aptitude for teaching. It will be said that the ordinary teacher would know nothing about the underlying principles. True; but we must have teachers 
who do. In France the rural elementary school children very commonly lunch with their parents in the fields, and do a iittle work with them during the midday break; on returning to school they have to talk about what they saw done, and the teacher tells them the Why and Wherefore.

Every Christian, every Churchman, should do his utmost to forward the movement, for it is the duty of every Christian to see to it, as far as he is able, that each and every future citizen has opportunity to develop to the highest point in body and soul. Religious instruction clearly should not stop at fourteen-it must continue, too, but it is hard to see how it can be fitted in to the eight hours of compulsory attendance. Other means must be found. Under whatever system is devised, the opportunity should be taken of simplifying the religious teaching given to children under fourteen. I fear very often the clergy do not understand what is suitable "for babes and sucklings."

There will be undoubtedly much opposition on the part of employers to giving up their youths for two afternoons in the week ; farmers particularly will complain. The clergy could do much in getting them to take the right view-in making them realize that the standard of labour will improve. In no country in the world, where continuation instruction is in force, have employers really suffered, once they have made the necessary adjustments. In Scotland farm lads have one afternoon off, and in Denmark their education goes on to eighteen. Far from ruining agriculture, the farmers in these two countries are the most prosperous in the world.

We have a great Education Act, but this alone is not sufficient ; we must have a public opinion and the will behind it to make it truly effective. Where necessary, Local Education Authorities must be stirred to take action under the Act, obeying rather its spirit than its letter.

And when necessary this pressure should be brought to bear upon the Local Education Authorities by local people, keen to see the needed development, rather than by the intervention of Central Authority. 


\section{APPENDIX III}

\section{ARABLE DAIRY FARMING}

A paper read by Mr. Fames C. Brown at the Farmers' Club,
December, 1920

\section{IIISTORY}

CTOCK-RIISING on arable land is a practice probably as ancient as agriculture itself, and methods of manage$N_{\text {ment early engaged the attention of writers on farming }}$ matters.

Much interest was shown in the subject in England in the eighteenth century, but during the nineteenth century it is but little written about. 'The records of the methods practised show that no logical system was ever established, the cropping being liaphazard, except in the case of the arable land sheepfarming of the South of England. With the general application of the four-course system during the last hundred years the special cropping of arable land for the maintenance of cattle seems almost to have died out in this country. There does not appear to have been worked out a system of keeping cattle entirely on arable land throughout the whole year; even in Denmark a proportion of grass is retained. In England arable stock-farming has been confined to arable sheep farming, and the occasional production of arable crops for feeding cattle to supplement the produce of grassland, which is practised to a limited extent in isolated cases in many districts. It must, however, be borne in mind that in the four-course system of farming the winter keep of all kinds of stock is drawn largely from the arable land. 


\section{DEVELOPMENT}

The abundance of grass produced in this country, together with the tendency towards an extensive system of farming, which was one of the chief characteristics of British farming during the second half of the nineteenth century, is no doubt largely responsible for the neglect of this branch of husbandry ; for while Denmark was making rapid progress in the development of this department of farming, and the dairying districts of America were more and more turning to forage crops as a means of feeding dairy cattle, the subject was almost entirely neglected in this country. An examination of the agricultural literature of the nineteenth century reveals surprisingly little information on the subject. The success of the Danes, however, invites the attention of farmers in this country, especially as in Denmark an increase in the yield per acre of cereals has accompanied the growth of arable stock farming.

\section{POSSIBILITIES}

In spite of the excellent climatic conditions for the production of grass existing in this country, the grassland is the weakest link in the farming system, and it is generally admitted that large tracts are making only a small contribution to the national food supply ; especially is the average yield of hay per acre from the permanent grass small. It has been proved beyond question that on average land a much larger head of stock can be maintained when it is under the plough than when it is in grass, the debatable question being whether an equal profit can be obtained from the capital involved, in view of the greater expenditure on labour involved and the greater risk attendant on arable farming operations. If it be possible to secure a reasonable return on the capital outlay, it would obviously be a great national advantage to increase the stockearrying capacity of the country, and, at the same time, make possible an increase in the average yield per acre of the 
cereals. The dependence of cereal crops on the stock of the farm is not sufficiently recognized, yield per acre being dependent mainly on the fertility accunulated from the application of farmyard manure; thus an increase in the quantity of dung produced on the farm would almost certainly result in the raising of the average yields of important cereal crops. The condition of food shortage throughout the world and the changed economic standing of this country render it desirable that a new period of intensification of the fundamental industry should be inaugurated.

\section{IIARPER-ADAMS EXPERIMENTS}

To test the possibilities of stock farming on arable land, experiments were commenced at the Harper-Adams College in 1909 , but owing to the lack of available information on the subject it was not until 1915 that a system had been worked out which would give a sequence of fodder throughout the summer months, and even then the succession suffered from many imperfections, which, however, have since been removed. The experiment at first aimed only at substituting for grass feeding for dairy cows during the summer months the produce of arable land. 'The cows were kept indoors, the fodder being carted to the cowshed and fed in specially designed racks, the cows being allowed out for water only. This system of management proved successful, and has been followed in succeeding years with equal success. The cows maintained perfect health and condition, and the yield of milk obtained was quite satisfactory. The success of the summer feeding on arable crops resulted in the experiment being extended so as to embrace the whole year. The system adopted has now stood the test of four years, and may be regarded as sound and reliable as far as the conditions of soil and climate existing in Shropshire are concerned. The system of cropping practised is shown in the following diagrams, eight years being taken to complete the course of cropping :- 


\section{THE LAND AND ITS PROBLEMS}

The SoILing Rotation.

Ist Crops.

\begin{tabular}{|c|c|c|c|}
\hline Crop. & $\begin{array}{l}\text { Seed per } \\
\text { Acre. }\end{array}$ & $\begin{array}{l}\text { Time of } \\
\text { Sowing. }\end{array}$ & Time of Cutting. \\
\hline $\begin{array}{l}\text { I. Giant Rye } \\
\text { Winter Vetches }\end{array}$ & $\begin{array}{l}2 \text { bush. } \\
\text { I " }\end{array}$ & \}$_{20 \text { Sept. }}$ & 8th-3 Ist May. \\
\hline $\begin{array}{l}\text { 2. Giant Rye } \\
\text { Field Peas }\end{array}$ & $\begin{array}{ll}2 & , \\
1 & ,\end{array}$ & \}$_{4}^{\text {th } \mathrm{Feb}}$ & Ist-I2th June. \\
\hline $\begin{array}{l}\text { 3. Winter Oats } \\
\text { Winter Barley } \\
\text { Winter Vetches }\end{array}$ & $\begin{array}{ll}\text { I } & , \\
\text { I } & , \\
I & \prime\end{array}$ & 28 th Sept. & I3th-3oth June. \\
\hline $\begin{array}{l}\text { 4. Wheat } \\
\text { Winter Vetches }\end{array}$ & $\begin{array}{ll}2 & \prime \prime \\
1 & \prime \prime\end{array}$ & $4_{4}^{\text {th Dec. }}$ & Ist-I6th July. \\
\hline $\begin{array}{l}\text { 5. Oats } \\
\text { Field Peas }\end{array}$ & $\begin{array}{ll}2 & \prime \prime \\
1 & \prime \prime\end{array}$ & I 5 th April & I7th July-Ist Aug. \\
\hline $\begin{array}{l}\text { 6. Barley } \\
\text { Field Peas } \\
\text { Vetches. } \\
\text { Field Beans } \\
\text { Oats }\end{array}$ & $\begin{array}{ll}2 & , \\
\frac{1}{2} & , \\
\frac{1}{2} & \prime \\
I & , \\
I & \prime\end{array}$ & $4^{\text {th }}$ May & 2nd-I6th Aug. \\
\hline $\begin{array}{l}\text { 7. Buckwheat } \\
\text { Peas } \\
\text { Rape }\end{array}$ & $\begin{array}{l}\text { I " } \\
\text { I }, " \\
4 \text { lbs. }\end{array}$ & 2oth May & I 7 th-3 Ist A ug. \\
\hline 8. Maize . & $\mathrm{I}_{2}^{\frac{1}{2}}$ bush. & 2oth May & Ist-3oth Sept. \\
\hline
\end{tabular}

2nd Crops.

$\left.\begin{array}{rl|c|c}\hline \multicolumn{1}{|c|}{\text { Crop. }} & \text { Time of Planting. } & \text { Time of Using. } \\ \hline \text { 9. } & \text { Cabbage . } & \text { I8th June } \\ \text { I0. } & \text { Cabbage . } & \text { 26th June } \\ \text { II. } & \text { Cabbage . } & \text { 6th July } \\ \text { I2. Cabbage . } & \text { 20th July } \\ \text { I3. Cabbage . } & \text { 5th Aug. }\end{array}\right\}$ Ist Oct.-I6th Feb.




\section{HiNter heep Rotation.}

Ist year. If Peas and Oats for Hay.

2nd year. I5 Wheat and Vetches or Oats and Vetches for Hay, planted immediately the crop is off the ground with cabbage.

3rd year. It Peas and Oats for Hay.

$4^{\text {th }}$ year. 16 Mangels and Marrow Stem Kale.

1920.

\begin{tabular}{|c|c|c|c|c|}
\hline$\stackrel{\square}{2}$ & \multicolumn{2}{|c|}{$\begin{array}{l}\text { Summer Keep } \\
\text { | Total Area. }\end{array}$} & $\frac{\circ}{a}$ & $\begin{array}{l}\text { Winter Keep } \\
\text { I Total Area. }\end{array}$ \\
\hline A & I & (9) & I & \\
\hline B & 2 & (IO) & 1 & 14 \\
\hline C & 3 & (I I ) & I & $I=5$ \\
\hline D & 4 & $\left(\begin{array}{lll}1 & 2\end{array}\right)$ & $J$ & 15 \\
\hline $\begin{array}{l}\mathrm{E} \\
\mathrm{F}\end{array}$ & $\begin{array}{l}5 \\
6\end{array}$ & (I3) & II & I 4 \\
\hline $\begin{array}{l}\mathrm{G} \\
\mathrm{H}\end{array}$ & $\begin{array}{l}7 \\
8\end{array}$ & & $\mathrm{~L}$ & I 6 \\
\hline
\end{tabular}

1921.

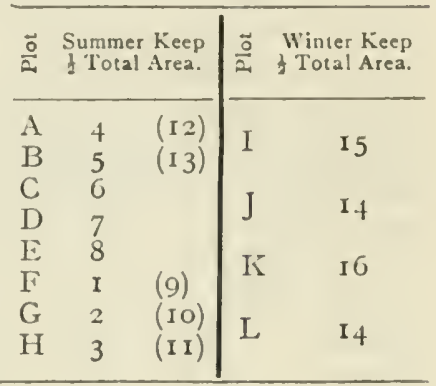

1922.

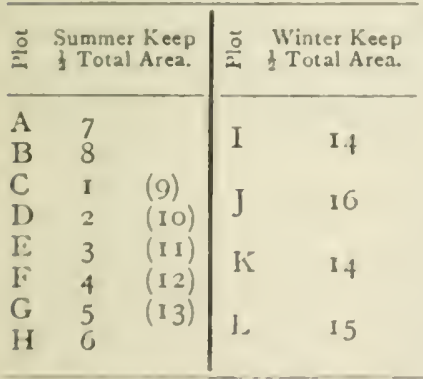

\section{3.}

\begin{tabular}{|c|c|c|c|c|}
\hline$\stackrel{\square}{a}$ & \multicolumn{2}{|c|}{$\begin{array}{l}\text { Summer Keep } \\
\text { I Total Area. }\end{array}$} & $\frac{a}{a}$ & $\begin{array}{l}\text { Winter Keep } \\
\text { Total Area. }\end{array}$ \\
\hline A & 2 & (I0) & & \\
\hline B & 3 & (I I) & 1 & IO \\
\hline C & 1 & (12) & & \\
\hline D & 5 & (13) & $J$ & If 4 \\
\hline$E$ & 6 & & IS & I 5 \\
\hline Ii & 7 & & II & 15 \\
\hline $\begin{array}{l}\text { G } \\
\text { II }\end{array}$ & $\begin{array}{l}8 \\
1\end{array}$ & (9) & L & I. 1 \\
\hline
\end{tabular}




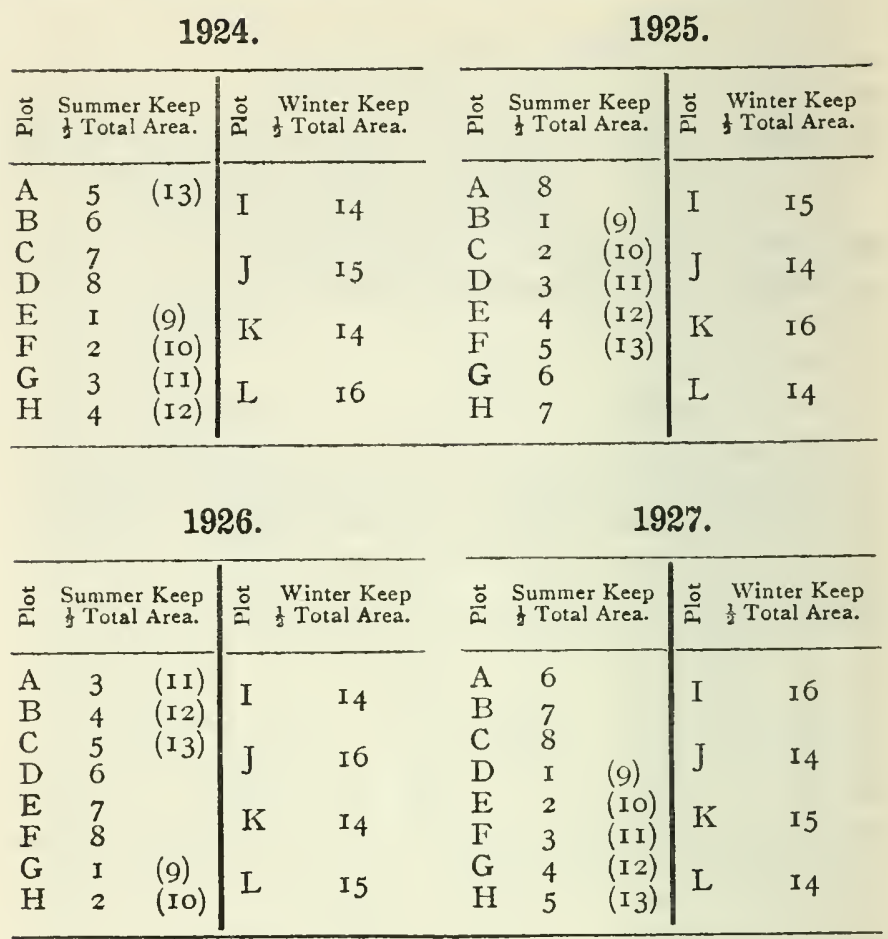

\section{8.}

\begin{tabular}{|c|c|c|c|c|}
\hline$\stackrel{\circ}{a}$ & \multicolumn{2}{|c|}{$\begin{array}{l}\text { Summer Keep } \\
\text { 1 Total Area. }\end{array}$} & \multirow[t]{2}{*}{$\ddot{O}$} & $\begin{array}{l}\text { Winter Keep } \\
\text { 1 Total Area. }\end{array}$ \\
\hline A & I & (9) & & \\
\hline B & 2 & (I0) & 1 & 14 \\
\hline C & 3 & (I I) & $T$ & \\
\hline D & 4 & (12) & $J$ & 15 \\
\hline $\begin{array}{l}\mathrm{E} \\
\mathrm{F}\end{array}$ & $\begin{array}{l}5 \\
6\end{array}$ & $(\mathbf{1} 3)$ & K & 14 \\
\hline $\begin{array}{l}\mathrm{G} \\
\mathrm{H}\end{array}$ & $\begin{array}{l}7 \\
8\end{array}$ & & L & I6 \\
\hline
\end{tabular}


The land is divided into two equal parts, one of which is used for producing the summer fodder, the other half provides the winter keep. The half providing the summer fodder also produces fodder in the form of the cabbage second crops, which is fed throughout the winter months.

The land used for the soiling rotation, which supplies the fodder during the summer, is divided into eight plots of equal size, each plot producing sufficient fodder for approximately eighteen days. The land from which the first five crops have been cut is immediately ploughed up and planted with cabbage, the remaining three plots being sown with crops for the following year. The rotation is designed to separate crops of similar character as much as possible in point of time, which has up to the present prevented any signs of crop sick:ness, while the land has steadily increased in productiveness. The soiling rotation detailed in the tables provides a complete and safe succession of fodder throughout the summer, when the dates of sowing named are adhered to, and the only failure to be recorded up to the present time is the maize crop. It has been decided to abandon this crop because of its uncertainty in Shropshire-very heavy crops have been obtained from time to time, but in a season such as the one through which we have just passed, maize, in Shropshire, is almost useless. The Mixture No. 7 in the Table will in future be substituted, when it is claimed the cropping is at least as reliable as anything can be in arable land cultivation. The rotation which provides the fodder for the winter months is, like the soiling rotation, designed to alternate the crops as far as possible, thus avoiding crop sickness in the soil.

The system now practised embodies the experience gained by a continuous series of experiments carried out since 1909 , during which time the chief weaknesses lave been eliminated. It has been the aim to discard all crops which do not give maximum yields, and it will be seen from the 'Table that only heavy yielding crops have been retained. 'The mangel is the only root crop included, as it must always remain one of the chief succulent crops of the dairy farmer. It is the most 
productive fodder crop available to British farming, and where an average of over 25 tons per acre is obtained it is not an expensive crop to grow. The combination of mangels with pea and oat hay adopted is probably more economical than feeding ensilage during the winter. It has proved remarkably successful in the experiments, and practical farmers who have tried the mixture speak well of it. Where heavy crops of mangel can be obtained they should be included in any scheme for intensive arable dairy farming.

\section{METHODS OF CULTIVATION}

The land on which the arable dairy farming at the HarperAdams College is being carried on is a strong loam tailing off to a red clay on one side and a sandy loam on the other. Part of it works freely, but one field is difficult to manage in wet weather; on the whole it is very well suited to the purpose. The plough is the most important implement of cultivation on a soiling farm, a type with concave mould-board being used for all work. Another implement of cultivation of great value is the Massey Harris spring-tined harrow, which gives exactly the soil tilth most suitable for forage crops. For the mixtures the land is ploughed seven inches deep with a wellbroken furrow, on which the seed is broadcasted, the springtined harrow following. No further cultivation is given, as the crops thrive better when the earth is left rough, and fewer weed seeds germinate. Rain water passes through such a seed-bed, thus consolidation of the surface is avoided. One drawback to having the land in this rough condition must be mentioned, i.e. the choking of the knives of the reaper during cutting.

The second crops are planted immediately after the first crops have been removed, the plants being raised in seed-beds in the same field and as near as possible to the place where they will be required. The practice of ploughing in the cabbage or kale plant has been adopted, after experimenting with a planting machine, and dibbling. Where skilled labour is 
available ploughing in has no advantages over dibbling, but where no skilled labour can be obtained results can be achieved which would be impossible by any other method. It is not cheaper than dibbling, but the work is less monotonous. In planting cabbage after fodder crops, it is very inportant that the plants be large and thick-stemmed. Such plants will live through almost any condition of adversity. The second crops are horse-hoed once only, and receive no hand weeding; this is sufficient to keep the crop quite clean. The small amount of labour involved in the production of the crops is worthy of note-Crop No. 3 in the Table, a mixture of winter barley, winter oats and vetches, followed by cabbage, may be taken as an example. The whole of the labour involved in producing the two crops is :-

Twice ploughing.

Sowing seed mixture broadcast.

Harrowing once.

Planting cabbage.

Horse-hoeing cabbage once.

Carting and spreading farmyard manure.

The cultivations are not costly, owing to the small number of operations involved, but the cutting and carting absorbs a good deal of labour.

One of the most interesting results of the experiment is the improvement of the texture of the soil as the result of the frequent growing of fodder crops. The effect of these crops on the mechanical condition of the soil is noted by many early writers, but appears to have been lost sight of in more modern times.

\section{CUTIING AND HANDLING THE CROPS}

Cutting with the scythe is expensive, but it is the only possible means of cutting badly laid crops, such as have been experienced in the past season. Since the commencement of the experiment, in no previous year lave the crops been so completely twisted and beaten down, and it was clearly shown 
that, in future, the mixture must, if possible, be so designed as to be capable of remaining erect under all seasonal conditions. Crop No. 6, although it yielded nearly 20 tons of forage per acre, remained perfectly erect, while most of the other mixtures were quite flat, and, because of this, was much more productive, quite half of the fodder from the other plots being left on the ground. This year Crop No. 6 mixture contained $\mathrm{I}_{2} \frac{1}{2}$ bushels of beans per acre, which provided the necessary strength to keep the crop erect. In view of this experience it is intended to add $\mathrm{I}$ bushel of beans to each mixture for the purpose of giving strength, so that the crops may be cut with a machine. The machine used for cutting the crops is an obsolete Hornsby manual delivery reaper, with which it is possible to bunch the crop as it is cut in quantities suitable for lifting with a fork on to a cart. When the crop is upright this method is very satisfactory, and the cost of cutting is very little. A hay bogey, with a low platform, has been used for carrying the fodder, but is not quite satisfactory, because of the low wheels which sink into the ground when wet, and make the draught too heavy. In dry weather the carriage is quite satisfactory, but a more perfect form of conveyor is required. It would seem that an open-sided wagon with high wheels and cranked axles to keep the platform low might be designed which would have all the advantages of the hay bogey without its drawbacks. Further, if the sides were made like ordinary hay racks the wagon might be drawn into the cattle-yard and the fodder consumed from the wagon, thus saving labour. The forage is heavy to handle, and should be lifted as little as possible, all feeding racks being placed on the ground.

\section{EFFECT OF THE SYSTEM OF CROPPING ON WEEDS}

Perhaps the most interesting information gained from the experiments under examination is the discovery that practically all weeds can be destroyed without special weeding, the crops themselves performing the weeding process. One field which contained a considerable quantity of docks, thistles 
and coltsfoot and some couch grass has been completely cleaned in four years, the only cultivation given being ploughing and horse-hoeing. The land is much cleaner than that farmed in the usual way, and resembles a garden in its freedom from weeds. This result was not hoped for when the cropping was commenced, the opinion of practical men being that the land would soon be choked with wceds. The reasons for this desirable result, however, become obvious when the process is examined. In the first place the crops make an extremely dense growth, and have an advantage over the weeds in growing with greater rapidity. Through being deprived of light and air the weeds are weakened, and when inverted by the plough immediately the crop is off the ground and planted over with large cabbage plants nearly all weeds are destroyed the first year. Couch grass is the most tenacious of life and the most difficult to destroy; it can, however, be killed by being persistently placed at a disadvantage compared with the fodder crop. This method of killing weeds would seem to have great possibilities applied to general farming practice. Crop No. 6 might be employed on a large scale for cleaning of foul land, and there appears to be no reason why this crop should not be used instead of a bare fallow. Couch grassthe worst enemy of the arable farmer-resists the smothering effect to a greater degree than other perennial weeds, because its roots grow horizontally and fill the earth, whereas the roots of other weeds assume a vertical position in the ground. To sow wceds of agricultural plants into ground choked with the roots of couch grass is to court ccrtain failure, and must be avoided. The roots of this grass, however, penetrate only to a depth of about 5 inches, and if the land be ploughed to a depth of 8 inches a seed-bed 2 inches deep and free from weeds will be secured, and the crop will have the necessary start. Couch grass buried decply is usually killed. 'This fact is clearly shown where a load of couch grass roots has been left in a heap for some time-only the outside layer of roots survise. The essential conditions for smothering out weeds are : I. A close-growing crop mixture is required; pure cereal 
crops allow the light to penetrate to the ground, and thus the weeds obtain the means of growth. It is interesting to note the difference in varieties of cereals themselves in their ability to keep down weeds-for example, land which has carried a crop of Clemrotheray oats will be much cleaner after harvest than land on which Record or Leader oats have been grown. II. Deep-ploughing, to bury deeply the roots of couch grass, and to cut the roots of such weeds as docks and thistles below the range of dormant buds. III. The turning of the furrow slice almost completely over in conjunction with a skim coulter, to avoid weed growth on the furrow brows. IV. It is of the greatest importance that the crop be sown immediately after the plough and before the perennial weeds have time to commence growth. V. Dressings of manures are valuable, particularly farmyard manure.

\section{PEA AND OAT HAY}

The dry fodder given during the winter months is hay made from a mixture of peas and oats. This crop gives very heavy yields -4 tons per acre having been obtained-is not difficult to make, and gives excellent results in feeding. To obtain the heaviest yields Clemrotheray or Dunn's oats should be sown. The crop should be cut when the peas have formed pods, but before they are filled with seeds, and it is necessary to leave the hay in large cocks for a considerable time, as it should not heat at all in the stack, and the stacks should be thatched as soon as possible, as water casily penetrates. Pea and oat hay has proved more effective in the production of milk than the best meadow hay.

\section{THE MANAGEMENT OF THE STOCK}

It has long been known that cows can be maintained in perfect health when kept entirely indoors, provided their treatment is correct. The plan adopted in the Harper-Adams system is to keep the cows tied up all the year, allowing about half an hour out of doors each day for exercise. The cows kept in this way have maintained their health and condition, 
and have milked well, the calves produced being healthy and normal in every way. All fodder is given without cutting or pulping, to save labour, a method which is quite equal to the usual practice when the stock have become accustomed to it ; however, aged cows which have been fed on pulped fodder do not thrive well during the first year, neither do cows taken indoors from grass. The soiling should commence immediately after the winter season. Cows taken in from grass may not settle down for some time, when the milk yield will rapidly fall. It is much better to place the cows under the system before calving rather than during the lactation period. The green fodder is given in racks, three times daily, the amount to be given is judged from the fullness of the animal, and no definite weights can be given, as cows differ in their requirements, and certain crops fill the aninals more readily than others. The weight of green fodder given has varied from $70 \mathrm{lbs}$, to $120 \mathrm{lbs}$. per day, the latter amount being the greatest weight fed. When more than go lbs. per day is given a considerable waste occurs. It appears to be quite impossible to injure cows by overfeeding with green fodder, providing they do not scour. If they begin to scour, dry pea and oat hay should be fed with the green fodder, and the quantity reduced. Cattle can only safely take a limited quantity of water, and when the fodder is wet they may be forced to take too much, and scour will result. Milk yield depends on a generous allowance of green fodder; in all cases when the green fodder allowance was reduced below So lbs. per head per day a sharp fall in yield was noticed. Concentrated foods are always given to the cows in milk; it is an error to suppose heavy yielding cows can be maintained in condition and yield on the fodder crops only, in spite of their rich composition. Frosted cabbage or kale can be fed safely, if they do not cause the animals to scour, but mangels that have been frozen are most harinful, and cause serious injury when given to stock. Of the green fodder used, the pea is the most effective in milk production. Pea mixtures have given consistently the best results since the commencement of the experiment. An 
example may be quoted: Twelve cows when changed from rye and vetches fodder to rye and pea fodder gave an increased yield of 18 gallons per week, although there should have been a fall due to the advancing period of lactation. When the fodder was changed to barley and vetches there was a sharp fall in the yield. Cows kept on the soiling system milk much better during the late summer, autumn and winter months than cows kept in the ordinary way, but the system cannot compare in milk production with grass feeding during the months of May and June.

\section{ECONOMIC CONSIDERATIONS}

When the experiment was commenced at the HarperAdams College there was practically no information available as to the most suitable methods of management of arable land having the maintenance of stock as its main object. Since the commencement of this experiment improvements have been made in the methods practised, and the scheme now in operation can be relied on to provide the necessary succession of forage, and is not more risky than other forms of arable farming; but experience has shown that to make the arable dairy farm a commercial success the produce must be put on the market during the period of high prices. It must be admitted that the arable dairy farmer cannot produce milk during May and June so cheaply as the grassland farmer, but he can produce it at a lower cost during the winter months. The arable dairy farmer who produced his maximum output during the glut period would not make a big profit. No system can compete with grass during May and June. The system of management outlined above is proved to be sound, but it would seem desirable in the light of experience to introduce modifications for general application. A very great increase in the national agricultural output could be secured by adopting the plan outlined in the diagram. Natural grass, mown for hay, is one of the weakest links in our farming, and might profitably be eliminated ; the hay required being produced on the arable land, where three times the weight can 
be obtained, the grass of the farm being entirely used for grazing, and made to carry three times the usual head of stock. The cattle would not be turned out until June, when the pastures would be well stocked with grass. At this periodthe time of cheapest milk-the cows would be dry. During June and July they would receive pasture grass only, in August, September and October they would feed on the pastures in part and in part on forage crops; during the winter they would be fed on the crops described above. By this method it is claimed the output of agricultural produce could be at least doubled without greatly increasing working costs.

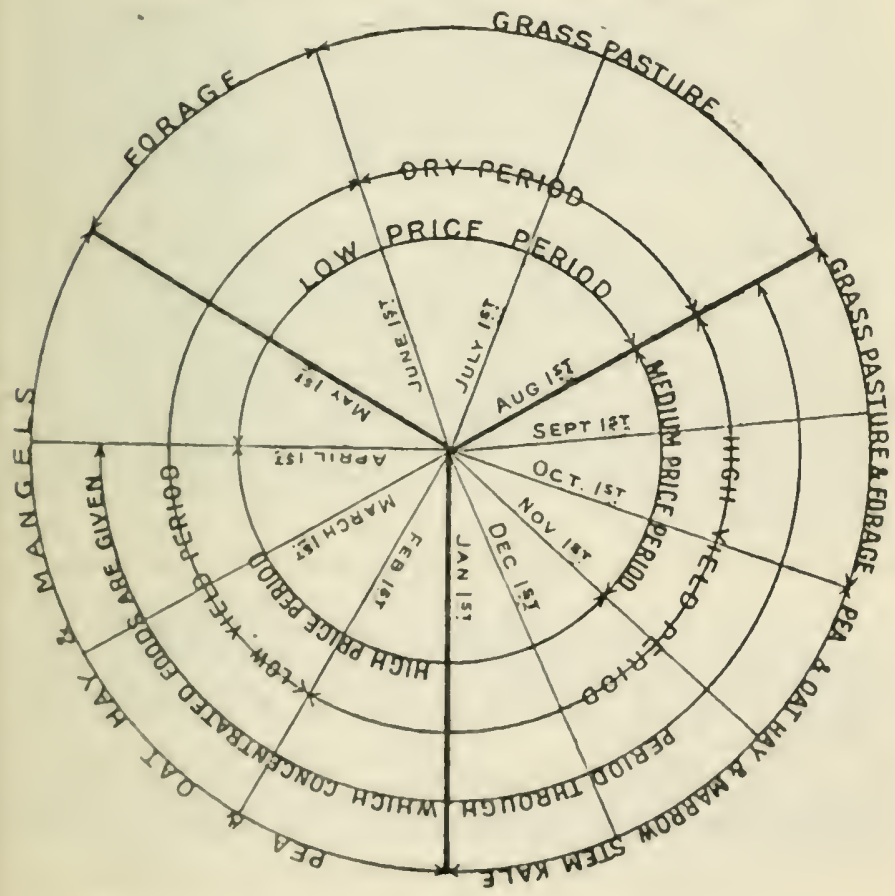




\section{APPENDIX IV}

\section{THE SETTLEMENT OF BRITISH EX-SERVICE MEN ON THE LAND IN THE DOMINIONS}

\section{INTRODUCTION}

7 Empire Land Settlement Committee of the Royal Colonial Institute requested me to investigate and

1 report upon the measures actually being taken by the Overseas Governments to place ex-service men on the land; what they were prepared to do for British ex-Service men; and how the pledges given to Sir Rider Haggard were being redeemed.

In making this enquiry I have ever kept clearly before my mind the system of settlement which the Royal Colonial Institute has consistently advocated since the formation of its Land Settlement Committee in I9I5. And as I am convinced personally, that the principles of settlement laid down by that committee are not only sound but essential, the criticisms I make and the conclusions I arrive at are all based upon these principles.

\section{GENERAL PRINCIPLES}

For the sake of completeness, I here state again the principles which, in the opinion of the Land Settlement Committee, must be observed in order to secure sound and effective settlement.

I. That settlers shall be placed on the land in groups or communities rather than as isolated units $;^{1}$ and experience

1 The group system in no way implies communism. 
has shown that in general terms the group should consist of at least 200 holders if the full economic advantages are to be secured.

2. That the settlers should own their farms rather than hold them as tenants.

3. That access to capital should be provided.

4. That complete arrangements should be made to provide the settler with expert guidance from the outset.

5. That co-operation should be encouraged.

6. That a system of organized transport is essential to the success of the community.

7. That the community spirit should be encouraged so that the settlers can build up for themselves a strong community life.

In the main it will be found that in whatever countries organized settlement has been effected, these principles have been observed. And now, more than ever before, it is of Imperial importance that every man placed on the land should become an effective producer of food with the least possible delay. The following quotation from a report of Mr. Elwood Mead, who is perhaps the greatest authority on scientific land settlement in the United States, not only puts the case in a nutshell, but I believe explains in a few words the attitude of the Royal Colonial Institute towards land settlement.

"The California Land Settlement Act provides for a demonstration in planned rural development. Instead of leaving things to happen and then correcting conditions when they happen badly, this State seeks through this Act to create organized rural neighbourhoods in accordance with carefully thought-out plans.

"The chief effort in private colonization of land has been to find purchasers rather than to create the kind of agriculture best suited to a region, to insure the success of scttlers with the least waste of money and effort.

"The neglect to provide intelligent direction and needed credit created a migratory and speculative spirit in pioneer communities." 
It is to be noted with satisfaction that in the leaflet addressed to ex-Service men who desire to settle upon the land in the United Kingdom, and which is issued by the Board of Agriculture, most of the principles of settlement as set out above are recognized.

\section{ADVANCE OF CAPITAL}

Unfortunately and regrettably, the advances for establishing the ex-Service men upon home land are much less generous than the provisions made by the Oversea Governments. It is strange that the provisions in the recent Act for equipping the ex-Service settler with the necessary working capital are not at all as good as those contained in the Small Holdings Act of Igo8. In the latter the civilian settler could borrow up to 80 per cent of his needed working capital ; under the present Act the ex-Service man can only borrow 50 per cent of the working capital he requires; in other words, he has to be in possession of one-half instead of one-fifth of the needed capital.

The Land Settlement Authorities in the State of New South Wales have adopted a policy in regard to advances to settlers which is so sound that it should be regarded as one of the best interpretations of principle No. 3. The Department's object is " to afford such assistance as may be necessary to give the settler an advantageous start in life, and so provide him with the basic requirements of his occupation as to enable him to make the farm productive of income as early as possible."

\section{CORRECT CONDITIONS}

\section{(a) OPPORTUNITIES OF SUCCESS}

The importance of settlement being effected under the best possible conditions, and, on the other hand, the disaster that results from placing men upon the land under wrong conditions, must outweigh all other considerations.

There is a world of difference between " exploitation " and 
" development," a difference which I fear is not always understood; there is a danger of using new settlers to develop a certain area of land-land that in due course should be developed, but which at the present moment does not offer the best prospects of success to the settlers ; and therefore it is wrong to send them there.

The success of the settlers must be the one aim and object, and it is the quickest and surest road to sound development of the land. It is clearly the duty of the Imperial Government to see that no such exploitation takes place.

\section{(b) IMPERIAL STRATEGY}

So much for the agricultural side of settlement; but there is another side of the problem of guiding the flow of population which is of supreme importance; I refer to what may be termed the strategic side. From the Imperial (and also national) point of view, what portions of the Empire stand in the most immediate need of filling up with settlers of English stock?

All the Dominions stand in need of population, but it does not require a lengthy study of the problem to come to the definite conclusion that it is Australia that stands in the supremest need of increasing its population.

In the case of Canada, following the same line of reasoning, British Columbia has the first claim upon the immigrants to that Dominion. It will be necessary for years to come to encourage migration to parts of the Empire where population is of most vital importance.

We have only a limited white population within our vast Empire ; it must be carefully husbanded, and above all every effort must be made to check emigration to foreign countries. We cannot in the present acute crisis afford to lose a single citizen.

In regard to agriculturists, the situation is even more serious. The Empire comprises over one-quarter of the land surface of the globe. Yet our agricultural population (i.e. all white 
men, women and children living on or by the land) is only $\mathbf{r}, 400,000$, compared with the agricultural population of $20,000,000$ in Germany, with its area only one sixty-fourth that of our Empire; or with $18,000,000$ in France on an area one-seventieth the size of our possessions, and a smaller total population than that of the United Kingdom. 'The gravest indictment of our policy (or want thereof) in regard to land and population lies in the fact that although we possess onequarter of the land of the world, our Empire is not selfsupporting. If these facts are once thoroughly understood, they constitute the strongest plea for a degree of organization and guidance of migration far beyond anything hitherto attempted.

The Royal Colonial Institute has done its best during the past four years to urge this plea, and unless the needed degree of organization and guidance is achieved, it is quite useless to talk about the white population of the British Empire reaching the grand figure of $200,000,000$ by the end of the present century. The best of our population will continue to stream into foreign countries and be lost to the Empire for ever.

\section{NEED OF CENTRAL AUTHORITY}

The question of the relation of the Imperial Government to the Overseas Governments in regard to settlement is one of great importance.

Having just completed a tour in Canada, New Zealand and Australia, and having studied the conditions prevailing in those countries, I state unhesitatingly that it is essential for the Imperial Government itself to take the initiative in organizing a settlement policy. We are parting with man power-our greatest asset-we are transferring it to other parts of the Empire : not only so, but the Imperial Government will have to provide large loans if effective settlement on a large scale is to be achieved. Therefore the Imperial Government has an indisputable right to guide population 
into those parts of the Empire which from the strategic point of view stand in greatest need of population; and further, it is its clear duty to see that the population so guided is settled under the best and most scientific conditions that can be devised.

It would not be difficult for the Home Migration Authority to influence the intending migrants in the right direction; in many cases they have no definite idea of the part of the Empire they wish to settle in. Sound advice would be welcomed and would be sufficient to turn the scale, it would in no way be a case of using " undue influence."

The first step must be the creation of a central and Imperial migration authority with requisite power to deal with this great problem as a whole.

The second step is for the Imperial Government, through the medium of the above authority, to enter into close consultation with the Overseas Governments in regard to migration. Time is passing, yet comparatively little has been done in this direction.

The third step should be the appointment of Imperial land settlement representatives in each Dominion.

As I have already stated, from the strategic point of view, Australia should be regarded as having the first claim to settlers from the United Kingdom. Fortunately it is the Dominion which offers the best opportunities for the settlers themselves; further the system of settlement in organized groups is more generally accepted than elsewhere in the Empire. But Australia is remote, and therefore special effort must be made to induce settlers to go to that country, otherwise many will simply drift to Canada because it is the nearest land to go to.

It is the time for frank discussion of the problem, and local views and susceptibilities must not be allowed to stand in the way of Imperial considerations, or of sending out migrants to the country in which they will succeed best and become must rapidly producers of new wealth. 'Two features which are noticeable in all the Dominions are the great shortage of 
agricultural labour for hire, and the tendency to give the new settler too large an area of land.

Therefore the British settler should not be given more land than he and his family can handle effectively without recourse to outside labour, and it should be remembered that the settler's economic position would be far sounder if he were to concentrate his capital upon a smaller area, and so secure a higher rate of working capital per acre than is customary with the Anglo-Saxon small farmer.

\section{EDUCATION}

As a corollary it would be a good plan for the Imperial authorities to organize an "educational " campaign amongst prospective settlers, possibly sending lecturers on emigrant ships as well. The object would be to give them some understanding of the unwisdom of taking up too much land, and the advantage of having a comparatively high rate of working capital per acre; also the advantage of settling on improved and partially improved land, even if they have to pay more for it.

Further, the lecturer could discuss the different branches of agriculture which the settler could most profitably go in for, in the country of his selection.

\section{TRAINING}

The question of the training of the immigrant will have to be carefully arranged for. In general terms the feeling in the Dominions is that the English settler should do a year's work on the land before taking up his holding. If the number of settlers annually is large the training colleges would only have room for a small proportion; the remainder would have to work for a wage on a farm.

With the shortage of agricultural labour little difficulty will be experienced in placing the men. The difficulty will be in 
finding suitable farmers-farmers who would be capable of training the men for their work on small farms.

It must be remembered that the majority of farmers who would employ immigrants would have farms of considerable size, and the methods of cultivation employed, far from assisting the small settler, might often put him on quite the wrong track. So that somehow or other he should be enabled to go through a course at a college, if only a short course.

In some ways, however, the ideal training is the training a man receives on his own holding, when this is situated in a properly organized colony with a first-rate superintendent. This is the method adopted by the Australian Farms, Ltd., in their Settlement at 'Tresco, Victoria.

In all dealing with immigrants the "human touch" is of great importance, and it is difficult for Government Departments to provide this.

It would be of much assistance if in each Dominion there existed a strong voluntary association, one of whose duties would be to "follow up " the new arrival; it seems probable that some such body will be started in Australia.

The foundation of a successful settlement must ever rest upon the wise and careful selection of the settler, his women folk not being overlooked if he has any.

Canada has appointed its selection authority in the United Kingdom; New Zealand and Australia will sooner or later do the same.

In the case of Australia it seems probable that each State will want to have its own selection committee, and we shall be overdone with selection committecs!

Throughout my tour the need of a strong central and Imperial inigration authority increasingly enforced itself upon me.

There is the newly created Oversea Settlement Committee, a step in the right direction, but it is not sufficient; an authority with much greater powers is needed. The Committee itself recognizes this, vide their Report (Cmd. 573).

Such an authority would exercise all its powers to keep our 
citizens within the Empire; next it would guide them to that part of the Empire where, from the strategic point of view, an English-speaking population is most essential.

It would see that in the first instance the settlers were placed upon land under such conditions that they would become successful producers of food in the shortest possible time.

The important fact to seize upon is that the Imperial Government must take the initiative, if there is to be organized migration and settlement. If the required amount of organization is not forthcoming, we shall lose thousands of our best citizens as in the past.

It is only logical that this central authority should be in the United Kingdom where lies the source of all English migration.

Loans will have to be advanced to Oversea Governments if settlement on a large scale is to be effected, and it will require an authority with the powers of a ministry if we are to have a real system of migration and settlement.

\section{FINANCE}

The question of financing settlement is a serious one ; there is abundant precedent for the Imperial Government to assist in finding the necessary money. It did so after the South African War, it did so in the early decades of the nineteenth century when it assisted the Wakefield Schemes of organized settlement in New Zealand and South Australia.

The need for this assistance is greater now than it was then.

With the work of placing their own men upon the land most of the Oversea Governments will not have the wherewithal to develop large schemes for the settlement of English ex-Service men, without the support and co-operation of the Imperial Government.

It is said that we are at the end of our financial tether and the outlook is most serious; however, the fact remains that we are finding large sums of money for reconstruction and for organizing our material wealth, but it is of vastly greater im- 
portance to organize our producers of wealth, and so to place potential producers that they may become effective producers of wealth in the shortest possible time.

Provided the principles of sound settlement are observed, no investment of public money can be more sound or more remunerative; but of greater importance-the Empire itself can be consolidated and built up only if we deal with the migration problem on right lines. The land and the men who cultivate it are the Empire's two greatest assets; they must be brought together and organized if we are to recuperate from the effects of the war.

Another great advantage that will accrue to the Imperial Government, if it is the medium through which loans for settlement oversea are effected, is that this will give it the right to assure itself that settlement is being carried out under sound conditions.

This is simply a business question : if the conditions of settlement are sound, money could be advanced under no better security; if the conditions are not sound, the money will be lost.

This would not necessitate any interference on the part of the Imperial Government-simply the discussion and agreement upon the conditions of settlement-all subsequent administration of that settlement would as a matter of course be in the hands of the Oversea Governments concerned.

\section{UNDERTAKINGS BY SETTLERS}

A further principle which should be observed is that, wherever our ex-Service men are placed upon the land and provided with working capital, they on their side should sign two reasonable conditions in regard to their holding.

Firstly, that they agree to buy no live stock for their holding, except with the approval of the settlement authority.

Secondly, that they undertake to follow the directions of the expert superintendent in regard to cropping and the use of artificials. 
From what I have seen myself, I am convinced that these two stipulations are essential. They are insisted upon by the State of California.

I have felt it advisable to lay stress upon these different points, as it will help to indicate the spirit in which I approach the problem of settlement in the Dominions. ${ }^{1}$

1 From the report to the Royal Colonial Institute, by Christopher Turnor, published by W. H. Smith at Is. $6 d$. 


\section{APPENDIX V}

\section{FORM OF AGREEMENT FOR FARMING PARTNERSHIP}

\section{Memorandum of Agreement between AB of}

on the one part, described as the owner, and $\mathrm{CB}$ of described as Manager, on the other part.

The said $C B$ agrees to act as manager of the Farm for the said $A B$ from the Sixth day of April, 19 to the Sixth day of April, 19 and so on from year to year, unless this agreement be terminated by six months' Notice in writing on either side.

It is agreed that the said $\mathrm{CB}$ shall be remunerated as follows :-

1. Thirty Shillings per week, being 20s. a week as wage and 10 s. as board allowance, together with the use of the farm-house.

2. A half share in the net profits of the farms as certified by an accountant; the net profits shall be the excess of the current receipts of the year over the current expenditure, in which shall be included-

(a) Rent.

(b) Five per cent on the working capital provided by the said $A B$.

(c) All other outgoings whatsoever, including the fixed allowance to the said CB.

3. The first f6o of the net profit and a half share in the remainder in any year in which the profits do not exceed $\mathcal{L}_{200}$ : when the net profit exceeds $\mathcal{L}_{200}$, then the said $\mathrm{CB}$ shall receive a half share as stated above. 
The said $\mathrm{CB}$ is to be entirely responsible for the management of the farm.

It is agreed between the said $A B$ and $C B$ that the working capital shall be $£$ per acre, or a total of $£$ and the said CB undertakes not to reduce this capital sum or to write off any portion thereof save with the full consent of the said $\mathrm{AB}$.

At the termination of this agreement the said CB shall receive one half of any increase in the total capital as ascertained by an outgoing valuation.

Should the said CB from any cause whatsoever neglect or cease to perform his duties, or should the said $A B$ at any time decide to sell or let the Farm, then the said CB agrees to accept six months' Notice to Quit, and upon the payment of such wages and other payments due to the said $\mathrm{CB}$ this agreement shall be void.

\section{Signed AB.}

CB.

The great advantage to the owner who goes in for partnership farming is, that he secures the services of a highly trained manager, whose whole interest it is to make the farm pay.

So that, under this system, the owner gets not only the rental for his land, and interest on his working capital, but he receives in addition a proportion of the farmer's profits.

The advantage to the partner manager is, that although he may possess no capital, yet he gets his chance; he starts on a farm of a size which it would otherwise have required years of saving on his part to take and capitalize.

On account of his participating in the profits, he is enabled to put by money, and in turn become a capitalist himself in the shortest possible time. 


\section{APPENDIX VI}

\section{A NEW LAND POLICY ${ }^{1}$ \\ (A spcech by a Cabinet Minister during the war)}

PLEA FOR A REVOLUTION

T ORD SELBORNE, President of the Board of Agriculture, speaking at the first of a series of lectures by Mr. Christopher Turnor, at the London School of Economics, on "The Land and the Empire," said that after the war the whole attitude of Parliament towards agriculture would have to be changed. The land question must be considered solely from the point of view of the security of the nation and national defence.

In the course of his speech Lord Selborne said that when the Anti-Corn Law League was a great political institution the Torics, headed by Mr. Disraeli, prophesied that Free Trade would be the ruin of agriculture. Mr. Cobden and Mr. Bright always denied that statement. For more than a generation they were absolutely right ; but it was no exaggeration to say that in 1880 a catastrophe fell upon British agriculture. From 1880 to 1900 was a time of dire distress for all connected with the cultivation of the soil. Our political economists had not studied that period carefully enough. Thousands of farmers were absolutely ruined during it. The services of the landowner during that period had not been anything like properly acknowledged, because, had it not been for the landowner, the agricultural depression would

1 Times licport, March 11, 1916. 
have been greater still, and many more acres would have fallen out of cultivation. The landlord farmed the land himself and farmed it unsuccessfully, but he kept the land in cultivation and the labourers employed. The result to him was the loss of half the capital the family had previously possessed. Another result was that brains and money were no longer attracted to farming. A change also took place in the ownership of land. Land again became a luxury for the rich and that was a great misfortune for the country.

These national calamities, land that ought to be cultivated lying uncultivated and the over-production of game, were not causes but effects. They were the result of the fact that land was owned by men who did not care what it produced, they had bought it for amusement, just as in the old days it was bought for political power.

\section{THE FUTURE}

We had all learnt much from the war. We had learnt the immense strength which was gained by a country if it could feed its own people. We had learnt the great value of a rural population. We had learnt the anxieties that were caused to a nation at war which had to import a large proportion of essential products from overseas during the war. Please God, this country should never have to undergo that experience again. But to secure that end we must so frame all our agricultural laws as to obtain the greatest possible national security.

I think (Lord Selborne went on) there ought to be nothing less than a revolution. We want to see the greatest possible number living on the land. We want to see the agricultural labourer assured of a good wage, a good house, and a good garden. More than that, we want to see him assured of the prospect of becoming a cultivator of the land himself and eventually an owner. We want, in fact, an agricultural ladder which will enable a man to rise on the land just as he can rise in any other walk of life. Then we want the farmer to 
be other than a man who chooses farming because he likes its outdoor life and the sport that is in it. We want all the brains we can get into agriculture as well as capital. We want men to go into farming not because it is a pleasant, healthy life, but because they can make money out of it. Lastly, we want landowning to be regarded, not as a luxury, but as a business requiring as much study and energy as any other profession.

In conclusion, Lord Selborne appealed to all political parties, whatever their views on the land question previous to the war might have been, to study the question afresh in the light of the experience obtained from the war, so that when the war was over, while it was hopeless to expect that we should all be agreed what the attitude of the State towards agriculture must be as to particular measures, we should at least be all agreed that there must be a complete recasting of agricultural life. 


\section{APPENDIX VII}

\section{NATIONALIZATION OF LAND}

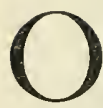

NE of the chief arguments put forward by land nationalizers is that the landowner asks exorbitant prices for land and so checks development in many directions.

Here we have a clear and definite statement, and it is quite as definitely an untruth.

It is agricultural land-not urban building or factory sites-which is here discussed; and what are the facts?

Firstly, that the agricultural land of Great Britain realizes less than its economic value when it comes into the market. It is the cheapest land in Europe, and it is cheaper than the land in the more settled parts of our Dominions.

Secondly, that although the value of land appreciated somewhat during the war, the increase was far less than that of any other commodity that was bought or sold. Taking average agricultural land that had a selling value of $£_{2} 0$ per acre in 1914, that value rose to about $f_{2} 25$ in 1917 or 1918 , which means-if the purchasing value of money be taken into account-that during the war, and since the war, average land was selling at less than its pre-war value.

A few cases of rich fen land may be quoted where $f_{0} I 40$ per acre was realized, but similar land in New Zealand, I2,000 miles from our great markets, is selling at $£_{1} 5^{\circ}$ per acre and more !

It is of fundamental importance to understand the truth in this matter, because very many untruths are told about the abnormal value of land by people who are either hopelessly ignorant of the subject, or wilful perverters of the truth. 
One would almost have thought that the experience we have just had of industries run by the State would have somewhat discouraged our nationalizers, but it does not seem to have had that effect!

However, there are indications of their shifting their ground; the nationalization of the industry, rather than of the land itself, seems to be increasingly the objective.

This suggestion is in no way less mischievous and dangerous than that of taking the land itself, for it would involve the running by the State of the biggest industry of all, and the nne hardest of all to manage.

Most of the people who advocate this are the very first to cry out against any suggestion of guaranteed prices or subsidy for the cultivators of the soil ; if they could give effect to their scheme, three things are certain-

r. That the land would yield less than ever.

2. That the cost of management would greatly increase.

3. That the subsidy that would have to be paid to the cultivator under this regime would far exceed the wildest limits ever dreamed of by any "vampire " agriculturist of to-day!

It is either a question of that or of the agricultural worker sweating, at a poor remuneration, to fill the bellies of the townsmen.

There is an idea abroad that every citizen should have the right of access to land, and that evcry labourer should be a manager of a farm : the ignorance of it all!

In an old and thickly settled country it is quite impossible for every citizen to have access to the land. We certainly should and could see a very much larger number working on the land; but after every effort in this direction it is doubtful if, even with the assistance of allotments, we could get more than half our population into direct touch with the land, and no system can be devised under which all the cultivators can act as managers.

In conclusion, it may be well to set out the aims and objects of the moderate nationalizers of land (as distinct from the extremists who would advocate confiscation). 


\section{THE LAND AND ITS PROBLEMS}

They claim that the results of nationalizing the land would be :-

I. That the community would thus be able to secure to itself any increased value of the land arising from State action, and so to prevent any benefit accruing to the individual from an increased value brought about by the community itself.

2. That speculation in land would be stopped.

3. That the community would benefit socially if the land were nationalized, for then it would be readily available for all future development.

4. That the proper control of cultivation would be secured.

5. That if farmers held their land under the State, fixity of tenure would be secured.

6. That it is essential to nationalize the land before railways and mines can be nationalized.

7. That it would secure easy access to the land for the largest possible number of people.

8 . That the single tax system could be introduced.

The question is, Is it necessary to nationalize the land to secure these objects? Are there not other methods by which to secure them-methods that would prove simpler, and which would not entail the risk of entirely upsetting the agricultural industry? And this risk is a real one. The great mass of farmers are opposed to State-ownership ; it could only be carried out in the face of their strongest opposition, and a lessened production over a lengthy period would be the inevitable result.

As a matter of fact, some of the aims as stated above have been achieved already by methods other than that of nationalization, and others are in process of achievement.

r. Increment duty is in existence, and it could be so applied that all increased value would go to the community wherever it was not due to the activity of the owner or expenditure of capital on his part.

2. Speculation will be stopped if increase in value is removed by taxation. 
3. In Germany methods were adopted for providing towns with the land they required for housing and public use without nationalizing all rural land. A really comprehensive Acquisition of Lands Act would remore the existing difficulties.

4. Occupying ownership gives absolute security and, when accompanied with the provision of a sound system of credit, the most wholesome security.

5. Railways have been nationalized without nationalizing the land.

6. A proper Acquisition of Lands Act, along with a properly devised Land Settlement Act, would secure easy access to the land.

7. The point in regard to single tax is hardly worth replying to, in view of the fact that for some years the National Budget will require a revenue of at least $f_{0}, 000,000,000$, and the total annual value of all land and houses in the United Kingdom does not amount to half that sum. 


\section{APPENDIX VIII}

7 HIS diagram is taken from the writer's book, "The Land and the Empire," published in I917. It shows 1 the development in and the extension of the Board of Agriculture he advocated; much of which has since taken place.

AS IT IS

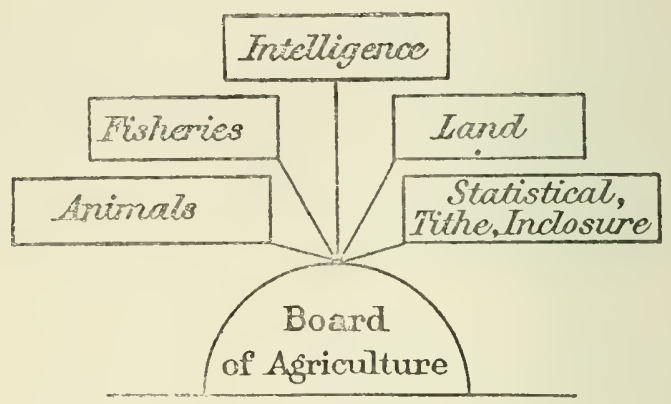

AS IT SHOULD BE

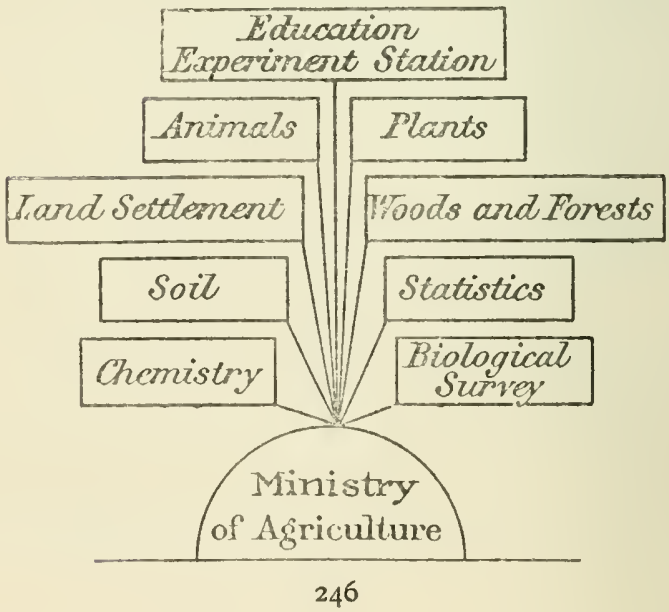




\section{APPENDIX IX}

\section{Diagram showing tile Proposed Organization of Agriculture}

(Taken from "The Land and the Empire.")

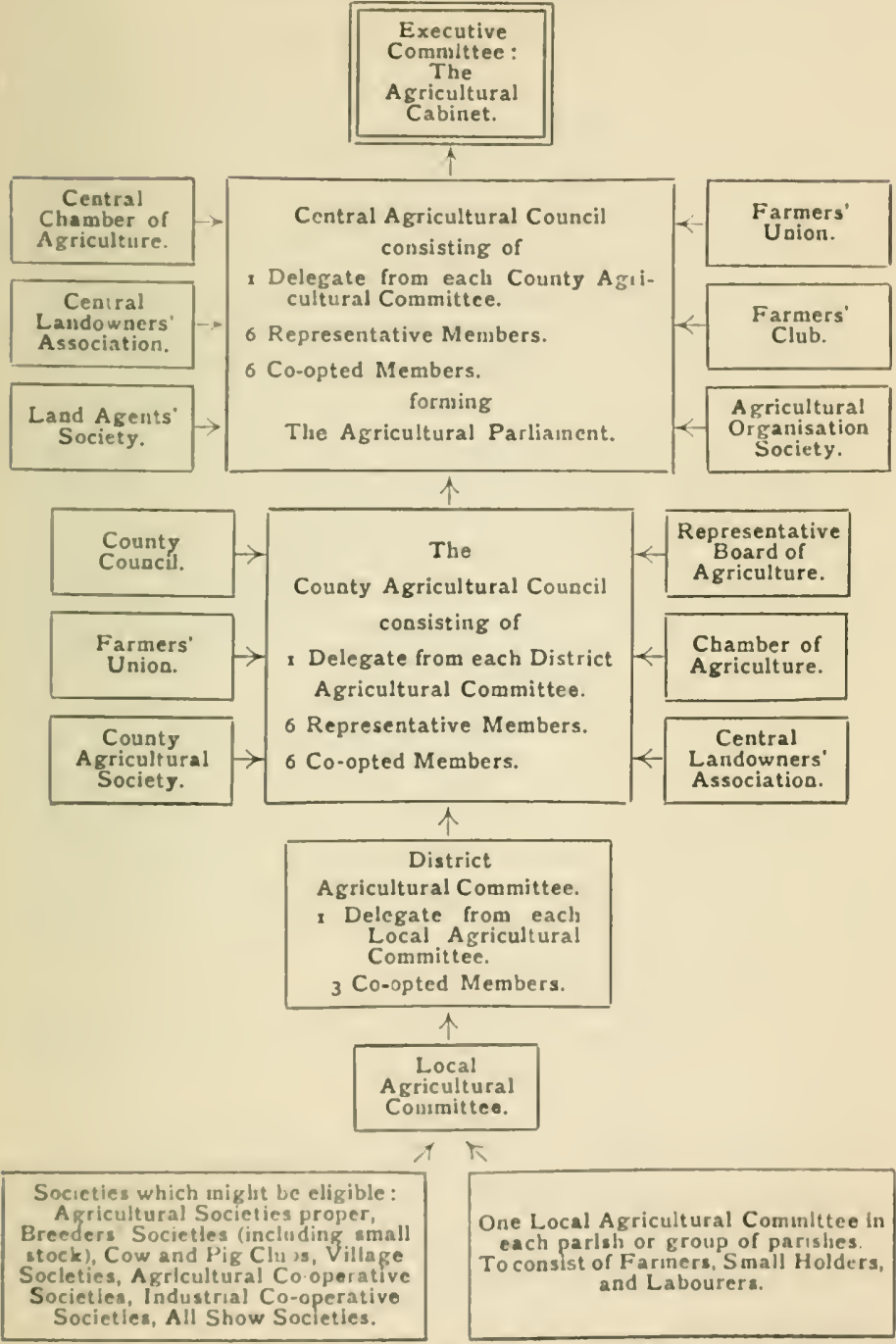

The chicf advartage of this scluene is that it is entirely unofticial, and as a voluntary organization it avoirls the demerits wbich arc alıeady appearing io our piesent semi-official or Ratization. 


\section{APPENDIX $X$}

\section{ON MACHINERY}

$\mathrm{M}$ ACHINERY is not used in England to anything like the extent it could be used, or that it is used in other countries with a highly developed agriculture.

But we must not fall into the error of thinking that everything can be done by machinery, or that the solution of all our agricultural difficulties lies in the full use of machinery ; some townsmen are inclined to think this.

On the other side undoubtedly many agriculturists think that a full use of machinery would make possible a great reduction in the number of landworkers employed, and a consequent lower wage bill per week.

It is necessary to be clear on this point ; machinery only reduces the number of men employed if it is deliberately used with a view to develop extensive cultivation. But our object is to increase the production from our soil, to develop intensive cultivation; machinery can play an important part in securing this development without reducing the number of men enployed, for, properly used, it will make each individual man more effective.

In Denmark, for example, much more machinery is used than in this country, and yet the number of men employed per 1000 acres is much higher.

It simply means that under more intensive cultivation, more labour, whether mechanical or manual, is used.

Undoubtedly there will be an increased use of tractors on certain soils, and other new machines, achieving efficiency and lessening cost of production, will be invented from time. to time. 
But I believe that the greatest results would be effected rather by altering the type of implements now in common use ; each implement should be put to the test : "Is this really econonic ?"

Take for example the question of wagons and carts; in most countries these are two foot six inches lower than ours, that means a saving of a two foot six inch lift on crery spadeful thrown into the wagon, and from careful observation I am convinced that this means an extra 50 per cent efficicncy for the worker engaged in wagon filling.

Again, the up-to-date drill for sceds or artificial manures can be worked entirely by one man, whereas most of our drills take a man and a boy, and some require two men and a boy, and yet do not cover half the ground that the one-man drill does.

There is no doubt room for great economies in these and other directions, in fact it is essential that we should study scientifically the question of the output of the individual worker, both from the purcly mechanical point of view and from the combined manual cum mechanical point of view as well. 



\section{INDEX}

Access to Land Act, 165

"Accommodation" land holder, 119

Accounts, Farm, 132 et seq.

Administration, 164

Advisory Committec, 169

Afforestation, 119

Agreement for farming partnership, 237

Agricultural College, 203

- Costings Committee, 104, 133. 134

- Council of England and Wales, 168

- depression, $17,43,50,72,104$

- cducation, $65,196,202,232$, 233

- labourer, 45,58

- progress, 33

Agriculture .1ct, $40,155,165$, $166 \mathrm{ct}$ seq.

- Chinese, 12

- Committee, 167

- Modern, dating from 1837,10

- Roman, 12

- Spanish, 13

Alfalfa. See Lucerne

Antwerp dock labourers, 85

Arable dairy farming, 2 I

- land, 99 ct seq., 158

Artificial manures, 17,96

Australia, 18, 233

Australian Farms, Ltd., 233

Austria, 205

I3acon factories, 120

Bakewell, I 6

Balance Sheet, for partnership purposes, 137

Bank, Agricultural, 84

lanks, land, 16.4
Barley, 92, 125

Bathurst, Charles. See Bledisloo

Belgium, 8.4-86, 117,203

Blacli Death, 23

Bledisloe of Lydney, Lord

(Charles Bathurst), 49

Board of Agriculturo, Extension of, 246

Book-keeping, Scientific, 133

Bran, 94

Britain, Great, Production of, 70

British Columbia, 229

Brown, Mr. James C., II I, 2 I I

Building, 121, 126

California Land Settlement Act, 227

Cambridge, 199

Campbell, Colin, 53

Canada, 204, 229, 233

Capital, $1+3$

- for ex-Service men, 228

- organized access to, 115

Career, Agricultural, if 1

- Inexperienced man with capital, IfI

- - the man with sinall capital, 145

Catherine, Queen, 13

Cattle versics sheep, 13

Central Chamber of Agriculture, $52,57 \%$.

- Landowners' Association, 49, 53,174

Cereals, $75,76,77$

Cheap food, 73

Chemical or artificial mamures, 17,96

Cheshire, 131

Cluristians and the land, 2 10

Church as landowner, 27 


\section{THE LAND AND ITS PROBLEMS}

Climate, IOO

Clover, I 2, 9 I , 93, 94

Clover sickness, 94

Colke of Norfolk, i 6

Commercial farming, I 55

Common rights, 20,44

Commune, 19

Company farming, 129

Competition of the New World, 88-90

Continuous wheat-growing, 98

Control, Government, I 57

Co-operative farming, 39, I I 6

- Societies, $8 \mathrm{I}$

Co-partnership farming, I 56

Country-woman and Society, the 204

County Agent or Organiser, I 49

- Agricultural Committees, 54

- Councils, I I 3, I 23 , I 46, I 47 , I 69

- Administration of Small Holdings, 113

Cows, 109, I I 9, I 25,2 I 3

- food for, 92

Creameries, I 20

Credit, Landschaft system in Germany, 48

- Societies, I64

- Denmark, 82

Cropping, I 53

Crops, Cutting and handling, 2 I 9

Cultivation Committees, I 72

Cultivator, the, I 9

Dairy farming, Arable, 2 I I

Demonstration farms, 139 et seq.

Denmark, 28, 31, 52, 65, 80-84, I I 9, I $25,134,146,201,2$ IO, 2 I I

Development of the land, I 79

Ecoles Ménagères Agricoles, $20_{3}$ Economic Council suggested, I 87 Edge, Mr., his Sussex farms, I 60 Education, 232

- Board of, 196, 202

- Fisher Act, 65

- New movements in rural, I96

Elizabeth, Queen, I 4
Empire Land Settlement Committee, 226

Enclosure, 20, 44

- Acts, 2 I

Equipment, I 2 I

Essex, I 24

Evesham, I 24

Ex-Service men, I 47

- - Settlement of, 226

- - Facilities Act, I I 7, I 49, I 67

Farm accounts, I 32 et seq.

- the Fruit, I I 7

- the Industrial, 129

- the medium sized, I 26

- the Poultry, I 5 I

- the small, I 18

- Lads' Clubs, 204

Farmer, the, 49 et seq.

Farmer's Union, 53, 55

Financial results, $106,107,123$, I 24, I 25, I 27

Fodder or soiling crops, 92, I09, I 58,2 I 4

Food, cheap, I 83

France, $86-88$, I I 7, 2 Io

Franco-German IVar, 87

Friendly Societies, 46, 64

Fruit farm, I 7

Germany, 29, 48, 52, 75-80, 100 , I04, I 28 , I 59, I 77, I $95,20 \mathrm{I}$, $203,230,244$

Grass land, 79

Grass versus arable land, I4, 99 et seq.

Great War, I 8, 30, 39, 43, 56, 88 , I 57, I 63

Guaranteed minimum price, 68

Haggard, Sir Rider, 226

Hall, Sir A. Daniel, K.C.B., M.A., I 35

Harper-Adams Agricultural College, IO9, 2 I 3,2 I 8,224

- - system, 158,163

Henry VIII, I 3, 27

Hours of work for agricultura! labourer, $6_{3}$

Housewife, the, 203

Housing, 22, 83 
Imperial Chamber of Agriculture suggested, is I

- considerations, 177

- Land Cunference suggested, I 1

Insurance, 64, 65

Jersey, 124

Lamarkshire, 118, 124, 200

Land Banks, 104

— Union, 49

Landowner, the, 4 I

- Farmer, 47

Lindowners' Union. Sec Central Landowners' Association

Lawes and Gilbert, of Roham. sted, 96

Lee, Lord, of Farnham, 104

Leguminous crops, 93

Licbig, 96

Lincolnshire, 64, 79, 127, 199

List's National System of Political Economy, 192

Live stock, 76, 79, 102, 103

London, Urban Authorities, 200

Lowitz, von Schwerin, 77

Lucerne, 12, 16, 94, 95, 125, 158, 162,163

Machinery, 248

Mackenzie, K. H., on Callle, 162

Manager, the Expert, 121,139

- Partner, 129

Mangolds, 91, 92, 125

Manures, Artificial, 17, 96, 164

- Farmyard, 17, 93, 95, 96

Market garden holdings, 117

Marketing, Organized, 115

Matthews, Sir Herbert, 181

Mead, Mr. Elwood, 226

IIetayer system, 26

IIddleton, Sir Thomas, K.C.B., II.A., 77 H., 98, 102, 103

Mlilk, $57,83,109,125,160$

Ministry of Agriculture, 37, 145 , 147,169

"Mir," 19

Mortgage, 48

Napoleonic Wars, 32, 39, 10.4
National Insurance .Ict, $46,6 . t$

Nationalization of land, 242

New Zealand, 35, 233, 242

Nitrogen, 17

Oats, 92,125

Objective in production, 153

Onslow, Lord, 49

Organization, 115,164

- of griculture, proposed, 247

Overseas settlement, 147,156

- - Bill, Is6

- Committec, 180

Ownership, occupying, 38

Oxfordshire, 64

Partnership system, 155

- - form of balance slieet, I3,

Peas, 12,94

Phosphates, 17

Pig-fecling, 159

Pig-keeping, 160

Pliny, 12

Poor Law Authorities, 203

Population, Agricultural, 177

Posidonious, 11

Potash, 17,164

Potatoes, $75,76,77,96,102,119$, 158,159

Potato spirit, I 59

Poultry, I6z

- Farm, 151

- and egg depots, 120

Production, yo et seq.

Profits from farming in Denmark, 82

- - arable and grass land (Strutt's report), Io6

__ - milk producing smallholding, 125

- - medium-sized farm, 127

- I'artnership, $14+4$

Prout, Mr., 9s

Pytheas, 10

"Reformers," 114

Rents, 42, 113,191

Richardson, Mr., Igricultural

Adviser of Victoria (Iustralia) 75

IRoman occupation, il cl seq. 


\section{THE LAND AND ITS PROBLEMS}

Root crop, 92

Rotation, Four-year, 91, 99

- Six-year, 98

- Variation in, 98

- IVinter keep, 215

Royal Colonial Institute, 226

Rumker, Professor von, 79

Rural education, 196 et seq.

- Worker's Insurance Society, 65

Russell, Mr., 204

Russia, I 9

Rye grass, 92

Scotland, 64, 98, i 56, 2 10

Scott, Leslie, Agricultural Opportunity, 176

Seeds, ley, 94

Selborne, Lord, 239

- Reconstruction Report, 176

Settlers, Undertakings by, 235

Sheep, 92, 93, I I 9

- versus cattle, I 3

Shropshire, 2 I 3, 2 I 7

Smallholders, 84, I 45, I 55

- capital required, I43

- income, 120

Smallholder, Continental, I 25

Small Holdings Act, I 908, 22, I I 3

- Colonies (Cheshire C.C.), $13 \mathrm{I}$

Small and large holdings, I I et seq.

Social status, 25

Soiling system, 92, IO9, 2 I 4

Spalding, I 25

State control, I 65

- interference, 27

Statutory Wage Board, 59, I67
Stock-breeding, 162

Strutt, Mr. Edward, I05, I 35

Suffolk, 25

Sugar, Home-grown, I 59

Sugar-beet, $77,79,83,158,160$ et seq.

Supervision, Organized, I I 5

Sweden, I 14

Swedes, 91, 92

Tenure, 30 et seq.

Trade Unions, 62

Training, I 47

Training of immigrants, 232

Transport, Organized, I I 5, I 64

Treasury, Imperial, I 39

Tull, Jethro, I 5

Turnips, I 5, 91, 92

Urban Insurance Societies, 64

Verney Committee, I9I6, II 7

Wage Boards, 67

Wages, 23, 24, 60

- Board Act, I67

Weeds, Effect of cropping on, 220

Wheat, $18,57,83,92,97,102$

Whitley Councils, 60, 69

Winchelsea, Lord, 22

Winter keep rotation, 2 I 5

Woman in relation to the farm, 204

Women's institutes, 204

Yorkshire, 64

- the North Riding, 27

The Mayflower Press, Plymouth, England. William Brendon \& Son, Ltd. 




\section{A SELECTION FIOO!I}

\section{MESSRS. METHUEN'S PUBLICATIONS}

This Catalosue comtains only a selection of the nore important books publivied by Messrs. Merbuen. A complete catalogue of their publications may be obtained on application.

Bain (F. W.)-

A Digit of the Moon: a Hindoo Love Story. ThE DFscrent of THE SUN: A Cycle of H'irth. A HEIFER OF THE DAWN. IN THE GREAT GOD'S HAIR. A DRAUGHT OP THE BIUE, AN ESSENCE OF THE DUSK. AN INCARNATION OP THF. SNOW. A MINE of Faults. Time Ashes of a Gov. BUBRLES OF THR FOAM. A SYRUP OF THE Bees. Thr LiYery of Eyf. The Sub. STAvcr of a DreaM. All Fcap. 8vo. 5 s. net. Ax Echo of тhe Spheres. Wide Demy. 125. 6d net

Balfour (Graham). THE LIFE OF ROBERT LOL'IS STEVIENSON. Fif. teenth Edition. In one Volume. Cr. Swo. Buckram, 75. 6d. net.

Belloc (H.)-

Paris, 8s. 6d. mé. Hills and the Sea, Gs. Nel. ON NothING AND KINDRED SUBJECTS 6s. net. Os EvERYTHing, Gs. net. ON SOMETHING, 6s. net. FIRST AND LAST, $6 s$. net. ThIS AND THAT AND THE OTHER, $6 s$. net. IIARIE ANTOsketTE, 185 . net. The PYReNers, ros. 6er. met.

Bloemfonteln (Blshop of). ARA CCELI : iN FSSAY iN MYSTICAL ThEOLOGY. Sccent/b Edition. Cr 800 . 55. net.

FAITH AND EXI'ERIENCE. Third Edition. Cr. 800. 5s. wct.

THE CUIT OF THE PASSING MOMENT. Fowrth Edition. C. $8 v 0$. ss net.

IHE FNCLISH CHURCH AND RE. UNION. Cr. 800. 55. net.

SCALA MUNLI. Cr. 800. 45. $6 d$ net

Cbesterton (G. K.) -

THE BALLAD OP THE White HORSE. All Thincs Considered. Tremendous Triples Alaris ano Discursions. A Miscelilany of Men. All Fcap. 8vo. 6s. net. WINE, WATgK, AND SONG. Fcap. 8vo. u. $6 d$ net.

Clutton-Brock( $\left.\boldsymbol{A}_{0}\right)$. WHAT IS THEKINGUOM OF HFAVEN? Fourth Edition. Fcap 850 ss, Net.

1.SSAYS OX ART. Secont Edition. Fcap. 8vo. ss. net.

Cole (G. D. H.) SOCIAL THEORY. Cr. Beo si. net.

Conrad (Joseph). TIIF. MIRROR OH IIIE SI.A: Memories and Jinpressions. Fourth fidition. Ficap, 8no. Gs, mat.
Elnsteln (A.). RELATIVITY : THL SPICIAL AND THE GENERAI. THEORY. Translated by ROBERT W. LAWS N. Cr. 800. Ss, net.

Fyleman (Rose.). FAIRIES ANI) CHIM. NEYS. Fcap. 800. Sirth Edition. 3s. 6it. net.

THE FAIRY GREEN. Third Edition. Fcap. 800. 35. 6d. ret.

Gibblns (H. de B.). INDUSTRY IN ENGLAND: HISTORICAL OUT. LINES. Witb Maps and Plans. Tentl Edition. Deme 850. 12s. 6d. net.

THE INDUSTR IAL HISTORY OF ENGLAND. With 5 ilaps and a Plan. Truenty.secuenth Edition Cr. 8vo. 5 s.

Gibbon (Bdward). THE DECLINE AND FALL OF THE ROMAN EMIPIRE. Edited, with Notes, Appendices, and Maps, by J. B. BURY. Illustrated. Scuen Volumes. Demy 3vo. Illustrated. Each 12s. 6d. nct. Also in Srien Volumes. Cr. 800. Each 75. 6d. net.

Glover (T. R.). THE CONFLICT OF REIIGIONS IN THE LARLY ROMAN EMPIRE. Eighth Edition. Demy 8vo. Ios. Git wet.

POETS AND PURITANS. Second Fitition. Desm. Sen. ros. 6d. net.

FROM PERICLES TO PIIIIIP. Third Edizion. Demy 8zo. 10s. 6rt. met.

VIRGIL. Fourth Edition. Demy $8 v 0$. sos, 6el. net.

THE CHKISTIAN TRADIIION ANI) ITS VERIFICATION. (The Angus Lecture for 19r2.) Second Edition. Cr. 8ro. 6.s. net.

Grahame (Kenneth). THE WIND IN THF WII.LOivS. T'enth Edition. C'r. 8vo. 7s. 6d. net.

HaII (H. R.). THE ANCIENT HISTORI OF THE NEAR EAST FROM TII. EARLIEST TIMES TO THE BATTLI: OF SALAMIS. Illustrated. howrth Edr . tion. Deme 8vo. 16s. net.

Hobson (J. R.) INTLRNATIONAI TIRADE: AN AFPLICATION OF ECONOMIC ThroRY, Cr. 8vo. 5s. et.

PROHLFMS OF POVEITY: AN INQUIRY INTO THE INDUSTRBAL CONDITION OF THE Pour. Eighth Editicn. Cr. 8vo. 55, wet. TIE IKOISLEM OF THE UN. F.MPI.OYKID: AIs INOUIKY AND AN Kcunomic Policy. Sixth Edition, Cr. 8vo. ss. mat. 
GOLD, PRICES AND WAGES : WITH AN EXamination OF THE QUANTITY ThEORY. Second Edition. Cr. 8vo. 5s. net.

TAXATION IN THE NEW STANE. Cr. 8vo. 6s. net.

Holdswortl (W. s.). A HISTORY OF ENGLISH LAW. Vol. I., II., III., Each Second Edition. Demy 800. Each I5s. net.

Ince (W. R.). CHRISTIAN MYSTICISM. (The Bampton Lectures of 1899 .) Fourth Edition. Cr. 8vo. 7s. 6d, net.

Jenks (E.), AN OUTLINE OF ENG. LISH LOCAL GOVERNMENT. Fourth Edition. Revised by R. C. K. ENsor. Cr. 8vo. 5s, net.

A SHORT HISTORY OF ENGLISH LAW: From THE EARLIEST TIMES TO THE END OF THE YEAR IgII. Second Edition, revised. Demy 8vo. 12s. 6d. net.

Julian (Ledy) of Norwich. REVELATIONS OF DIVINE LOVE. Edited by Grace Warrack. Seventh Edition. Cr. 8vo. 5s. net.

Keats (John). POEMS. Edited, with Introduction and Notes, by E. de SÉLINcourt. With a Frontispiece in Photogravure. Third Edition. Demy 8vo. ros. 6d. net.

Kipling (Rudyard). BARRACK-ROOM BALLADS. 205th Thousand. $\mathrm{Cr} .800$. Buckram, 7 s. 6d. net. Also Ficap. 800. Cloth, 6s. net; leather, 7s. $6 \mathrm{~d}$. net.

Alse a Service Edition. Two Volumes. Square fcap. 8zo. Each 3 s. net.

THE SEVEN SEAS. I52nd Thousand. Cr. 8vo. Buckram, 7s. 6d. net. Also Fcap. 8vo. Cloth, 6 s. net; leather, 7 s. 6 d. net. Also a Service Edition. Two Volumes. Square fcap. 8vo. Each 3 s. net.

THE FIVE NATIONS. 126th Thousand. Cr. 8vo. Buckrasn, 7s. 6d. net. Also Fcap. 8vo. Cloth, 6s. net; leather, 7s. 6d. net.

Also a Service Edition. Two Volumes. Square fcap. Swo. Each 3s. net.

DEPARTMENTAL DITTIES. 94th Thou sand. Cr. 8vo. Buckram, 7s. 6d. net. Also Ficap. 8ve. Cloth, 6s. net; leather, 7s. 6 d. net.

Also a Service Edition. Two Volumes. Square fcap. 8r. Each 3 s. net.

THE YEARS BETWEEN. Cr. 800. Buckrain, 7s. 6d. net. Alsu on this paper. Fcap. 8vo. Blue cloth, 6s. net; Limp lambskin, 75. 6d. net.

Also a Service Edition. Two Volumes. Square fcap. 8vo. Each 3 s. net.

HYMN REFORE ACTION. Illuminated. Ficap. to to. Is. 6d. net.

RECESSIONAL. Illuminated. Fcap. $4^{\text {to. }}$ Is. 6d, net.

TWENTY POEMS FROM RUDYARD KIPLING. 360th Thousand. Fcat. 8vo. Is. net.

Lamb (Charles and Mary). THE COM PLETE IVORKS. Edited by E. V. LUCAS. $A$ New and Revised Edition in Six Volumes. With Frontispiaces. Fcap, 8vo. Exch 6s. net.
The volumes are :-

1. Miscellaneous Prose. I1. Elia anv the Last Essay of Elia. III. Books for Children, Iv. Plays and Poems. $\checkmark$. and VI. LETTERS.

Lanlester (SIr Ray). SCIENCE FROM AN EASY CHAIR. Illustrated. Thirteent/2 Edition. Cr. 8vo. 7s. 6d. net.

SCIENCE FROM AN EASY CHAIR. Illustrated. Second Series. Third Edition. Cr. 8vo. 7s. 6d. net.

DIVERSIONS OF A NATURALIST. Illustrated. Third Edition. Cr. 800. 7s. 6 d. net.

SECRETS OF EARTH AND SEA. $C r$. 8vo. 8s. $6 d$ net.

Lodge (sir oliver). MAN AND THE UNIVERSE : A STUDY OF THE IN FLUENCE of THE ADVANCE IN SCIENTIFIC KNOWLEDGE UPON OUR UNDERSTANDING OF Christanity. Winth Edition. Crozun $8 v 0$. 7s. 6 d. net.

THE SURVIVAL OF MAN : A STUdy iN UNRRCOGNISED HuMAN FacUlty. Seventh Edition. Cr. 8 vo. 7s. 6d. net.

MODERN PROBLEMS. Cr. 800 . 7s. $6 d$.

RAYMOND; OR LIFE AND DEATH. Illustrated. Tuelfih Edition. Deny 800 . 15 s. net.

THE WAR AND AFTER: SHORT CHAPTERS ON SUbjects of Serious Practical IMPORT FOR THE AVERAGE CITIZEN IN A.D. rgrs ONWARDS. Eighth Edition. Fcap 8vo. 2s. net.

Lucas (E. Y.).

The Life of Charles Lamb, 2 vols., $21 s$. net. A WANDERER IN HOLLAND, ros. $6 \%$ net. A WANDERER IN LONDON, IOs. $6 d$. net. LONDON REvisited, ios. $6 d$. net. A WAN DERER IN PARIS, Ios. $6 d$. net and $6 s$. net. A WANDERER IN FLORENCE, IOs. $6 d$. net. A Wanderer in Yenice, 105.6d. net. The OPEN ROAD: A Little Book for Wayfarers, 6s. $6 d$. net and 7s. 6d. net. THE FRIENDLY Town: A Little Book for the Urbane, $6 s$. net. FIREsIde AND Sunshine, $6 s$. net. Character and Comedy, 6.s. net. The Gentlest ART: A Choice of Letters by Entertaining Hands, $6 s$. $6 d$. net. THE Second Post, $6 s$, net. Her Infinite Varietv: A Feminine Portrait Gallery, $6 s$. net. Good Company: A Rally of Men, $6 s$. net. ONE DAY AND ANOTHER, $6 s$. net. OLD LAMPS FOR NEw, $6 s$. net. LoITERER's Harvest, 6s. net. Cloud and Silver, $6 s$. net. LISTENER'S LURE: An Oblique Narration, 6s. net. OVER Bemerton's: An Easy-Going Chronicle, 6s. net. MR. INGLEsidE, $6 s$. net. LONDON LAYENDER, $6 s$. net. LANDMARKS, 6s. net. A BosWELL OP BAgHDAD, AND oTHER Essays, $6 s$. net. 'Tw1Xt EAgIE AND Dove, 6s. net. ThE Phantom Journal, andother Essays and Diversions, 6s, net. The British School : An Anecdotal Guide to the British Painters and Paintings in the National Gallery, $6 s$. net. 
McDonfall (WHHIam). AN INTRODUC. TION TO SOCIAL PSYCIIOLOGY. Fifieenih Edition. Cr. 8ro. 75. 6el. ne\%

BODY AND MIND: A HISTORY AND A DBFBNCE OF ANIMISM. Fowrth Edition. Demy 8ro. 12s. 6d. net.

\section{Maeterlinck (Maurlce)-}

Thx Blue Bird: A Fairy Play in Six Aces, 6s. net. MARY MAGDAleNe: A Play' in Three Acts, ss. net. DEATH, 3s. Gd. net. OUR ETENNITY, á. net. THE LiNkNOWN Guest, 6s. met. PoEMs, 5s. net. Thi WRACK OF THE STORM, Gs. net. THE Miraciz of St. ANThonv: A Play in One Act, 3. 6. xet. THE BURGOMASTER OF StIlsmonde: A Play in Three Acts, 5s. met. Th⿱ ВеткотиаL; or, The Blue Bird Chooses, 6s. met. Mountain PAтнs, 6s. net.

Mllne (ג, 1.). THE DAY'S PIAY. THE HOLdDay ROUNd. ONCF a IVEeK. All Cr. 8ro. 7s. met. NOT that It MATTBRS. Fcap 8re 6s. net.

\section{Oxenham (John)-}

BEEs IN AMBE : A Litile Book of Thoughtful Verse. ALL'S WKLL: A Collection of War Poems. The King's High Way. The Vision Splfandid. The Fierv Cross. High ALtars: The Record of a Visit to the Battlefields of France and Flanders. Hearts Coukagrous. All Clear! Windos of THE DAw. All Small f'oll 800. Paper, 1s. 3d. net; cloth boards, 25 . act. GentLemEN-TuE Kisig, 25. zet.

Petrle (W. H. Plinders). A HISTOKY OF EGYPT. lliustrated. Six Volumes. Cr. Bos. Essih os. Mt.

VOL 1. FroN THR IST TO тнB XVITH Drsasty. Winth Fdition. tos. 6rl. net.

VOL II. THX XVIITH AND XVIIITH Dynasters Sixth Eation.

VOL III. XIXтн to XXXтh DVNastiks. Second Edition.

VOL. IV. EGYFT UNDFR THE PTOLBMAIC Drinasty. J. P'. Maliafpy. Second Edition.

Vol V. EGVPt under Roman Rule. J. G. MILNR Second Rdivion.

VOL VI. FGYTt IN THE MIDDLF AgFs. Stanley Lane Poole. Second fidition.

SYRIA AND EGYPT, FROM THE TELI, EL A.IARNA LETTERS. Cr. 800. s. net.

EGYPTIAN TALES. Translated from the Papyri. First Seriea, tvib to xutb Dynasty. lllustrated. Third Edition. C\%. 8io. 5. mit.

FGYPTIAN TALFS. Translated from the Papyri. Secund Series XvIITH to xixTII I)ynasty. Illu trated. Second Fidition. Cr. 880. ss. net.

Pollard (A. P.). A SIIORT HISTORY OF IIHE GKLAT WAR. With 19 Maps. sacond fidision. Cr. 800, ros. Gd. nat.
Price (L. L.) A SIIOKT IIISTORY OF POLITICALI.CUNOMY IN LNLCANI) FROM ADAM SMITH TO AKNOLD TOYNBEE. Ninth ËLstion. Cr. BEo. 55. ne?

Rold (G. Archdall). THE LAWS OF HEREDITY. Second Edition Lemy 800. EI Is. net:

Robertson (C. Grant). SELF.CT STAT. UTES, CASES, AND DOCUMENTS, 1660-1832. Third Edition. Demy 8:0. 15s. net?

Solou: (Edmund) TOMMY SMITH'S ANIMALS. Illustrated. Eightecnik Edi. tion. ficap. sto. 35. 6et. net.

TOMMY SMITH'S OTHER ANIMALS. lllustrated. Eleventh Edition. Ficap. Bvo. 35. 6 t. net.

TÖMMY SMIITH AT THE ZOO. Illustrated. Fowrth Edition. Ficap. 800. as. 921 .

TOMMY SMITH AGAIN AT THE ZOO. Illustrated. Secont Ecition. Ficap. Boo. 2s. ad.

JACK'S INSECTS. Illustrated. Cr.8vo. 6s. wet.

JACK'S INSECTS. Popular Edition. Vol. 1. Cr. 800. 35. $6 i$.

Shalley (Percy Bysshe). POEMS. With an Introduction by A. CLUTton-13nock and Notes by C. D. Locock. Tuo Vulwmes. Demy 800. Eit is. net.

Smik (Adam). THE WEALTH OF NATIONS. Edited by EDWIN Cannan. Treo Voummes. Second Eidition. Demy 8ev. Ei ss. net.

Stevenson (K. L.). 'IHE LETTERS OF' RUBERI LOUIS S'IEVENSUN. Edired by Sir Sidney Colvin. A Airu kiearramed fidition in four golumes. Fourth Edition. Fcap. 8vo. Each ós. He?

Surtees (R. S.). HANDLLI CROSS. lllustrated. Vinth Edition. Ficap. 8vo. 75. out. net.

MR. SI'NNGE'S SPORTING TUUR. lllustrated. Fijth Eidition. Fcap. Bito. 75. 6ut. wet.

ASK MAMMA: OR, THE RICIHES CONMONER IN ENGLANU. IIIUS. trated. Second Eidition. Fcap. 8vo. 75. 0.t. net.

JURROCKS'S JAUNTS AND JOLLI. TIES. lllustrated. Srucwik firtition. Ficap. 8vo. 6s. net.

MR. FACLY KOMFORD'S IUUNDS. lllustrated. Therd Eduion. Ficup. 8vio. 75. Gd. net.

IA WBUCK GRANGL; OK, THL SPOKT. IXF AUVENTUKl:S OF THUMAS SCUTT, Hsa. Illustrated. Ficap. 8to. 6s. net.

I'LAIN OR RINGLETS? IIILIraled. ficap. 8ro. 2s. Get. nst.

HILLIN(i)ON HALL. With za Coloured Hates oy WILDKAKB, IJEATנ, and JKLI.l. cor. Ficap. 800. 7s. 6.d. net. 


\section{Leaders of Religion}

Edited by H. C. BEECHING. With Portraits

Crown 8vo. 3s. net each volume

\section{The Library of Deyotion}

Handy Editions of the great Devotional Books, well edited. With Introductions and (where necessary) Notes Small Pott 8vo, cloth, 3s. net and 35. 6d. net

\section{Little Books on Art}

\section{With many Illustrations. Demy I6mo. 5s. net each volume}

Each volume consists of about 200 pages, and contains from 30 to 40 Illustrations, including a Frontispiece in Photogravure

\begin{tabular}{|c|c|}
\hline 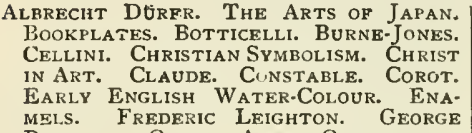 & 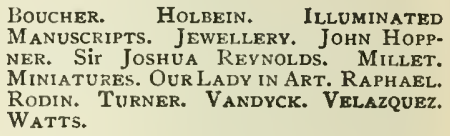 \\
\hline
\end{tabular}
ROMNEY, GREEK ART. GREUZE AND

\section{The Little Guides}

With many Illustrations by E. H. NFw and other artists, and from photographs Small Pott 8vo. 4s. net and 6s. net

Guides to the English and Welsh Counties, and some well-known districts

The main features of these Guides are (1) a handy and charming form; (2) illustrations from photographs and by well-known artists; (3) good plans and maps ; (4) an adequate but compact presentation of everything that is interesting in the natural features, history, archæology, and architecture of the town or district treated.

\section{The Little Quarto Shakespeare}

Edited by W. J. CRAIG. With Introductions and Notes Pott 16 mo. 40 Volumes. Leather, price Is. $9 d$. net each volume Cloth, is. 6 d.

\section{Nine Plays \\ Fcap. 8vo. 3s. 6d. net}

Across The Border, Beulah Marie Dix. / Kismet. Edward Knoblock. Fourth Edi. Cr. 800 .

Honeymonn, The. 4 Comedy in Three Acts. Arnold Bennett. Third Edition.

Great ADVenture, The. A Play of Fancy in Four Acts. Arnold Bennett. Fifth Edition.

Milestones. Arnold Bennett and Edward Knoblock. Ninth Edition.

Ideal Husband, AN. Oscar Wilde. Acting Edition. tion.

Typhoon. A Play in Four Acts. Melchior Lengyel. English Version by Laurence Irving. Second Edition.

Ware Case, The. George Pleydell.

General Post. J.E. Harold Terry. Second Edition. 


\section{Sports Series}

Mllustrated. Fapp. Svo. 2s. net and 3s. net

All About Flving, 3s. net. Golp Do's AND Dont's. ThE Golming Swing. How to Swim. Laivin Texist, 35. met. Skat.
ING, 35. net. Cross.Country Ski-ing, s.s. met. Wrestling, 2s. net. Quick Cuts TO GoOD GOLF, 2s. 6it. ne:.

\section{The Westminster Commentaries}

\section{General Editor, WALTER LOCK}

\section{Demiy Svo}

THE dCTS of тнв Arostles, 16s. net. Amos, \&s. 6d. wet. 1. Corinthians, 8s. 6et. net. ExoDUs, 15s. net. EzEKIEL, 125. 6. met. GENEsis, 26 , net. HeBrew's, 8s. 6d. nut. ISAIAH, IǴ. met. ЈЕREMIAH, 16s. net. Jов, 8s. 6d, net. Тнв РАstกkAL Epistles, 8s. 6\%. net. Тне Philipjians, 8s. 6d. net. ST. JAMEs, 8s. 6d. net. Sr. MATrHEw, 15s. net.

\section{Methuen's Two-Shilling Library}

Cheap Editions of many Popular Books

Fcap. Svo

\section{Part III.-A Selection of Works of Fiction}

\section{Benuett (Arnold)-}

Clavhangre, 8s. net. Hilda Lessways, 8s. 6d. ne?. THzSE Twain. THE CARU. The Regent: A Five Towns Story of Adventure in London. THв Price or LUVE BURIED ALIVE. A MIAN FROM TKR North. The Matadok of the Five TOWNS. WHOM GOD MATH JOINED. A Gizat MaN: A Frolic. All 7s. 6d. net.

\section{Birmingham (George A.) -}

Spantsr Gold. The Seakch Party. Lalage's Lovers. The BAD TimBs. UP, THE ReHELS, $A l l$ 7s. $6 d$. net.

\section{Burroughs (Edgar Rlce)-}

TARzAN or THE APrS, 6s. net. Thв KyTUKN OF TAKzan, es, met. THY lipasts Or TAKzAN, 6r. net. I he Son op TAkzAN, 6s. met. JUNGLE TAI.rs or TARZAN, Gs. met. TAKZAN AND THE JEWELS OF OrAK, 6s. net. TAKLAN TUE UTTAMKD, 2s. 6d, net. A PRINCRss of MARs, 6r. net. THK GuUs DF MAKS, G. net. THR WARLORD OF II ales, Gs. ret.

Conrad (Joseph). A SET OF SIX. Fourth kation. Cr. Bro. 7s. Gr. net.

VICTORY: AN ISLAND Tale Sirih Edition. Cr. Bue. q. met.

\section{Corelll (Marle) -}

A Romance or Two Worlds, 7s. 6t. net. VendetTA : or, The Story of One Forgotien, 8s. net. Thelin: A Norwegian Princess, 3s. jet. net. A DАтH: The Story of a Dead Self, 75. 6d. net. Тне Sioul or LiLITH, 75. 6.1. net. WORMwOоD: A Drama of Paris, 8s. nel. BAкABвAs: A Dream of the World's Tragedy, 8s. net. ThE Sokrows or Satan, 7s. 6d. met. TiIE MastrerChristian, 8s.6d. net. Thmpokal Power: A Study in Supremacy, 6s. net. Guv's Goon Mav: A Simple Love Siory, 8s. 6ut. net. HoLv OrDRKs: The Tragedy of a Quiet Life, 8s. 6d, net. Тнк Мıя гу Атом, 75. 6d. net. Bov: A Sketch, 75. 6.1. net. Camros, 6s. ret. Tra Lipe Everlasting, 8s. 6r. net.

Doyle (SIr R. Conan). ROUNDTHE RED LA.MP. Tu'clfth Edition. Cr. B80. 78.6d. net.

\section{Hichens (Robert)-}

Tongues of Conscirnce, 7s. 6ri. met. Firlix: Three Vears in a Life, 75. 6ut. net. Tur WoMan with TIIR FAN, 75. Git. met. livewavs, 7s. (d. net. TUR TaknNy ov AlLAil, 8s. 6d. net. I HF. Call ir TIIK HuNow, 8s. Git. net. I'ARHAKy Sirger, hs.

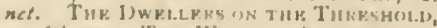
75. 6d. net. THE WaV OF AMBIION, 75. 6d. wet. IN тHX WII. DEKNess, 7s. 6d, wr? 


\section{Hope (Anthony)-}

A Change of Air. A Man of Mark. The Chronicles of Count Antonio. Simion Dale. The King's Mirror. Quisanté. The Dolly Dialogues. Tales of Two People. A Servant of the Public. Mrs. Maxon Protests. A Young Man's Year. BEaumaroy HOME FROM THE WARS. $A l l{ }_{7} s .6 d$. net.

\section{Jacobs (W. W.)-}

MANY CARgoes, 5s. net and 2s. 6d. net. SEA URCHINS, 5s. net and $3 s$. 6.2. net. A Master of CRAFT, $5 s$. net. Light Freights, 5s. net. The SKIPrER'S WooiNG, 5s. net. AT Sunwich PorT, 5s. net. Dialstone Lane, 5s. net. Odd Craft, 5s. net. THE LADY OF THE BARGE, 5s, net. Salthayen, 5s. net. SallorS' KNOTS, $5^{s .}$ net. SHORT CRUISES, 5s. net.

London (Jack). WHITE FANG. Ninth Edition. Cr. 8vo. 7s. 6d. net.

\section{MoKenna (Stephen)-}

Sonia: Between Two Worlds, $8 s$. net. NiNETY-Six HOURS' LeAYE, $7 s$. Gd. net. The Sixth Sense, 6s. net. Midas \& Son, 8s. net.

\section{Malet (Lucas) -}

The History of Sir Richard Calmady : A Romance. The Wages of Sin. The Carissima. The Gateless Barrier. DeAdham Hard. All $7 s .6$ d. net.

Mason (A. E. W.). CLEMENTINA. Illustrated. Ninth Edition. $\mathrm{Cr} .820 .7 s$. 6d. net.

\section{Msxwell (W. B.)-}

Vivien. The Guarded Flame. Odd Lengths. Hill Rise. The Rest Cure. All 7s. 6d. net.

\section{Oxenham (John)-}

A Weaver of Webs. Profit and Loss. The Song of Hyacinth, and Other Stories. Lauristoiss. The Coil of Carne. 'The Quest of The Golden Rose. Mary All-Alone. Broken Shackles. "1914." All 7 s. 6 d. net.

\section{Parker (Qilbert) -}

Pierre and his People. Mrs. Falchion. The Translation of a Savage. When VALMond CAME To Pontiac: The Story of a Lost Napoleon. AN ADYENTURER OF THE North: The Last Adventures of 'Pretty Pierre.' The Seats of the Mighty. The Battle of The Strong: A Romance of Two Kingdoms. The PoMp of THE Lavilettes. Northern Lights. All 7s. $6 d$. net.

\section{Phillpotts (Eden)-}

Children of THE Mist. Sons of THE Morning. 'The River. The American Prisoner. Demeter's Daughter. The Human Bov and the War. All $7 s .6 d$. net.

\section{Ridge (W. Pett)-}

A Son of the State, 7s. 6d. net. The Remington Sentence, 7 s. 6 . Madame Prince, $7 s$. $6 d$. net. Top Speed, 7s. $6 d$. net. Special Performances, 6s. net. The Pustling Hours, 7 s. 6 d. net.

\section{Rohmer (Sax)-}

The Deyil Doctor. The Si-Fan. Mysteries. Tales of Secret Egypt. The ORchard of Tears. The Golden SCORPION, All $7 s$. 6 d. net.

Sxianerton (F.). SHOPS AND HOUSES. Third Edition. Cr. 8vo. 7s. 6d. net. SEPTEMRER. Third Edition. Cr. $8 v 0$. 7s. 6it. nit.

Wells (H. G.). BEALBY. Fourth Edition. Cr. 8vo. 7s. 6d. net.

\section{Williamson (C. N. and A. M.)-}

The Lightning Conductor: The Strange Adventures of a Motor Car. LAdy BeTty ACross the Water. Scarlet RunNer. LoRd LOVEland Discovers AMERICA. The Guests of Hercules. It Happened in Egypt. A SOldier of the Legion. The Shop GiRL. The LightNing CONductress. Secret History. The Love Pirate. All 7s. 6 d. net. Crucifix CORNER. 6s. net.

\title{
Methuen's Two-Shilling Noxels
}

Cheap Editions of many of the most Popular Novels of the day

\author{
Write for Complete List
}

Fcap. 800 


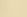


This book is DUE on the last date stamped below

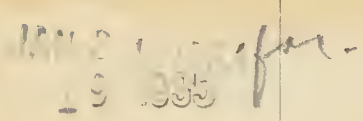

JUN 1 . 196]

Furm L-9-35m-8,'28 


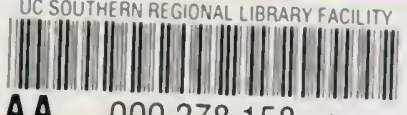

AA 000278158

HD

1927

1921

T86

UKIVEKSITY of CALIFUKNL

I US ANGELES

IJRRARY 


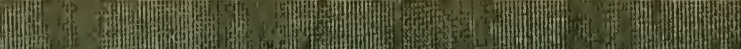

(1)

tr.

$4 m^{2}$ s.

(a)

$4 m^{2}$

(m)

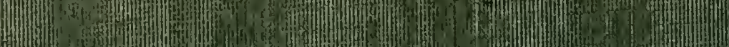

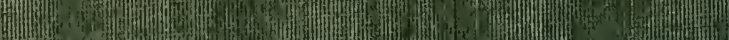

HE

H. H H. H. I.

(3) (E)

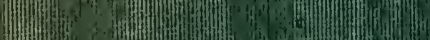
(t)

math

H. (M) 